\title{
Mitigation the Geohazard of Carbonate Karst Features in Construction Sites by Applying of Combined Techniques in (Kinta Valley) Perak - Peninsular Malaysia
}

\author{
Riyadh R. Yassin ${ }^{1}$ \\ Department of Geology, Faculty of Science \\ University of Malaya \\ 50603 Kuala Lumpur, Malaysia
}

\author{
Samsudin Haji ${ }^{2}$ \\ Department of Geology, Faculty of Science \\ University of Malaya \\ 50603 Kuala Lumpur, Malaysia
}

\author{
Ros F. Muhammad ${ }^{3}$ \\ Department of Geology, Faculty of Science \\ University of Malaya \\ 50603 Kuala Lumpur, Malaysia
}

\begin{abstract}
This research study focuses on the combination of geological, geophysical, aerial photographs and satellite images techniques as identification techniques to assess, mitigate and monitor the potential geo-hazard of various classes of carbonate karst features extend in the surface and subsurface of construction sites. These techniques have coupled with the engineering surface and subsurface remediation techniques and performed across five(5) selected construction sites distributed over a region of carbonate karst environment in north and south of Ipoh city (Kinta valley), Perak state, Peninsular Malaysia.

The carbonate karst bedrock in the area represents one of the most complicated ground conditions, its riddle with various solution features, which might be detrimental to any overlaying structures in its vicinity. These karst features such as sinkholes, caves, voids, cavities, channel pipes, depressions, conduits, internal drainages system, solution-widened joints, intensely fractured zones and faults. Thus, creating problems can directly or indirectly affecting the foundation of structures when overlapping carbonate karst environment sites.
\end{abstract}

The substantial damage resulting from carbonate dissolution features such as sinkholes was resulting through the construction works could cause massive losses all over the region. It will be directly or indirectly affect the construction structures. Indirectly have the potential to cause catastrophic damages in the near future or perhaps many years after the project has ended.

It can precipitate cracking in the building and halt the construction project totally. In addition, it will maximize the cost of the project overall. Other problems also may cause in the area such as the settlement of the houses or the buildings. In addition, the negative consequences that could precipitate years after the project has completed will result in massive losses that lead to enormous financial costs, to both the developers and the lands.

Several subsurface karst features were recognizing in these construction sites, during the utilization of high-resolution geophysical site characterization, by applying of Twodimensional (2D) Winner's Electrical Resistivity Tomography (ERT) technique, to capture the images of the subsurface in order to pinpoint evidence for near-surface karst features.

Resistivity traverses have conducted along the survey area at each construction site. The orientation, extension, and the degree of inclination of those traverses have shown in the location map. The resistivity data from the multi-electrode measurements from several profiles have collected and corrected. Then the correct resistivity data was interpreting by using the (res2dinv software) and plotted in the tomography sections.

This study also proved that high- resolution Electrical Resistivity Tomography (ERT) can effectively be employed to reflect the bedrocks. It is also completely suitable for differentiating surficial soil, clay, weathered rocks, compact or intact rocks, and air-filled karst voids or cavities, and intensely fractured rocks. The interpretation of geophysical techniques can help civil engineers to identify the irregularity in subsurface karst topography of marbleized limestone bedrocks in Perak, the degree of karst level, and identify what causes these karst features. Five construction sites have chosen from numerous construction sites that are studying.

The geological model is clarifying via the geophysical data, consists of a basal marbleized limestone unit and constitutes the bedrock of the study area. This bedrock unit appears to have been dissected or intervened by solutionwidened joints and fractures, enclosed by overburdened layers consisting of sand, containing lenses of stiff, non- stiff moisturized clay and covered by soil mixed with friable sand and rock fragments in certain places. Intervened by sinkholes and cavities in-filled with clay or sandy clay and sand; it is interpreted as created due to karst process.

In addition, the difference in the depth of bedrocks varies from one site to another; in site\# 1 , it varied from $17 \mathrm{~m}$ to $>28.0 \mathrm{~m}$. In site\# 2 , the depth varies from $20 \mathrm{~m}$ to $>28.0 \mathrm{~m}$. In 
site\# 3 , the depth varies from $6.0 \mathrm{~m}$ to $>28.0 \mathrm{~m}$. In site \# 4 , the depth varies from $1.5 \mathrm{~m}$ to $22.0 \mathrm{~m}$, and in site\# 5 , the depth varies from $3.0 \mathrm{~m}$ to $>28.0 \mathrm{~m}$.

The interpretation of the inverse model section in construction site \#1 indicated that the area has been affected by an irregular tabular channel that contain stiff, non-stiff moisturized clay, and sandy clay over karstified marbleized limestone. The interpretation of the inverse model section in construction site \#2 indicated that the area has been affected by a thick covering of alluvium deposits containing several sinkholes and lenses, filled with both stiff and non-stiff clay that is highly moisturized, rendering the area hazardous over karstified marbleized limestone. The interpretation of the inverse model section in construction site \#3 indicated that the area has been affected by many channel pipes, with soil cover collapse sinkholes containing both stiff and sandy clay, and sand over karstified marbleized limestone and cavities. The interpretation of the inverse model section in construction site \#4 is indicative of the fact that the area has affected by various fractures in bedrocks that contain both stiff sandy clay and sand. The interpretation of the inverse model section in construction site \#5 indicated that the area has been exaggerated by a massive sinkhole, thus containing stiff and non-stiff clay that is saturated with water, rendering the area hazardous to any projects.

In accordance with the engineering classification of karst ground conditions by Waltham A.C., Fookes P.G. (2005), the karst in these construction sites is extreme karst.

Through studying the karst regions in Malaysia found that the strength of the karstification process is different from one site to another in the same region. A geo-technical table for engineering classification of karst ground conditions which presented by Yassin, R., R \& Haji, Tap, S. (2012) which describe the subsurface features that come upon in engineering works on the carbonate karst environments, after applying of the geotechnical survey. This table applies in Malaysia peninsular and includes five (5) classes, start from Youthful karst (KaI) and ending with extremely complex karst (KaV).

The karst class in construction site \#1 found between traverse no. 1, traverse no.2 is adult karst, and between traverse no.3, traverse no.4 is a mature karst KaIII. The karst class in construction site \#2, found between traverse no.1, traverse no.4 is a mature karst KaIII. The karst class in construction site \#3 found between traverse no.1, traverse no. 2 is a mature karst KaIII, and in traverse, no.3 is a complex KaIV. The karst class in construction site\#4 found between traverse no. 1 and traverse no. 4 is a mature karst KaIII. The karst class in construction site\#5 found between traverse no.1 and traverse no.6 is a mature karst KaIII - Complex karst KaIV.

The geotechnical survey identifies that the thin red cover that contains the different sizes of granite rocks and minerals with thickness is mostly about $(5.0 \mathrm{~cm}-12.0 \mathrm{~cm})$. This thin red cover found over a layer of lateritic clay with different thickness from site to another between $(1.0 \mathrm{~m}-1.25 \mathrm{~m}),(2.0 \mathrm{~m}$ $5.0 \mathrm{~m})$ and with the maximum thickness $(6.0 \mathrm{~m}-9.0 \mathrm{~m})$ are mostly returns to the period of a global flood (Noah's Flood) (33003100) BCE.

The appearance of this thin red cover and the layer of lateritic clay are due to runoff heavy rains that have deeply eroded and washed both the highest granite ranges around the Kinta valley and then carried away by the new rivers and canyons that formed due to the erosion. A thin layer of carboniferous organic material with different thickness of $(3.0 \mathrm{~cm}-5.0 \mathrm{~cm}),(8.0 \mathrm{~cm}-10.0 \mathrm{~cm})$ have seen beneath the lateritic clay.

There are several causes for the occurrence of sinkhole collapse in the Kinta Valley; the primary reason among them is the irregular distribution of unconsolidated material on the bedrocks surface. The secondary reason is the running of heavy rainwater on the ground surface. The third reason is the heavy acidic rainfall in this region. The fourth reason is the earthquakes and the subsidence movement. The fifth reason is the heavy loads of buildings or foundations. The sixth reason is the human influence. The seventh reason is the vibration from traffic. The eight reasons are the weather patterns. The ninth reason is the groundwater movement. The tenth reason is the water quality. The eleventh reason is Air high pollution. All these reasons after the development of the sinkholes and other karst feature rapidly in this tropical area of Peninsular Malaysia.

Early planning of engineering subsurface remediation techniques are needs to mitigate or minimize the potential of geo-hazard of karst features and its deposits in these construction sites over carbonate karst environmental bedrock. The initial consideration is to utilize the reverse graded filter technique to fill the huge sinkhole in construction. Skin friction piles have driven into the layers that contain non-stiff materials (soil, clay, silt, sand). Drive off long piles down to the sound bedrock due to the difference in the depth of bedrock from one side to the other.

Furthermore, it requires a new process of grouting method in the study areas of those sites such as chemical grouting techniques. Besides, they need to control of surface and subsurface water drainages. All of these plans must put into operation in these construction sites when the work is going to start at these respective sites. One of the steps of environmental management in oil and gas exploration uses bentonite drilling mud and the rock gutting from the drilling operation after the water and other liquids have removed to refill the depressions and sinkholes in karst regions.

This study also discusses many considerations about the important elements that play major roles in the development of karst phenomena and the dissolution process in (Kinta Valley). Mining and human activities, air and water high pollution, and heavy rain developed the karst features rapidly in this tropical area of Peninsular Malaysia.

Keywords: Mitigation, Geohazard, Carbonate Karst Features, Construction Sites, Combined Techniques, Perak- Peninsular Malaysia

\section{INTRODUCTION}

The topography and depth of carbonate bedrocks such as dolomitic limestone or marbleized limestone in Perak are important for engineering construction projects such as buildings, housing complexes, and highways. Sinkholes cause hazards in construction sites that overlay carbonate rocks causing construction delays, stability problems, which may amplify the increase in cost due to cracking of walls, building foundation collapse, road with pavement subsidence and cracking. These are only some examples of the problems associated with sinkhole, karst cavity and voids. Structural instability associated with these features can arise as a result 
of the sudden collapse of the ground surface or as a less catastrophic but recurring drainage problem.

Within the construction sites over the carbonate karst environment, the design and execution will be expensive regarding present and future structures. In addition, borings drilled within karsts regions do not overlap the complete pictures of the required areas in the subsurface. Inappropriate and mismanaged borings cannot provide ample subsurface data for analysis and at the same time can also misrepresent the subsurface system that may lead to additional cost for corrective design or additional analysis. Rapid reconnaissance surveys using (satellite images and surface geophysical techniques incorporated with a boring plan) are the best obtainable options that can be used to aid in the suitable location of test borings to identify or distinguish the subsurface features related to karst development.

The $2 \mathrm{D}$ resistivity imaging technique was preferred for the subsurface investigations instead of other geophysical methods for the high contrast or disparity in resistivity values between different types of sediments like carbonate rock and clay or soil, air or water in-filled cavity or voids compared to the bordering or surrounding limestone bedrock. These entire elements reflector reproduce the use of resistivity imaging method to outline and delineate the boundary between bedrock and overburden. Apart from that, this method is not unmanageable in respect of time for small-scale projects in both pre ability and post ability processing steps, making it most appropriate for investigations.

A two-dimensional (2D) electrical resistivity tomography (ERT) survey has carried out across five construction sites in Perak state. Construction site \#1 is located at Batu Gagah in the southwest of Ipoh city. Construction site \#2 is located at Rapat in the southeast of Ipoh city. Construction site \#3 is located in Ipoh city. Construction site \#4 is located at Taman Tasek Raya in the north of Ipoh city. Construction site \#5 is located at Klebang Putra - Klebang Green to the northwest of Ipoh city, Perak state, Peninsular Malaysia. The location of construction sites covered by combined survey techniques presenting in the Google normal, Google terrain maps (2013) of Kinta Valley, Perak state, peninsular Malaysia, figure 1.

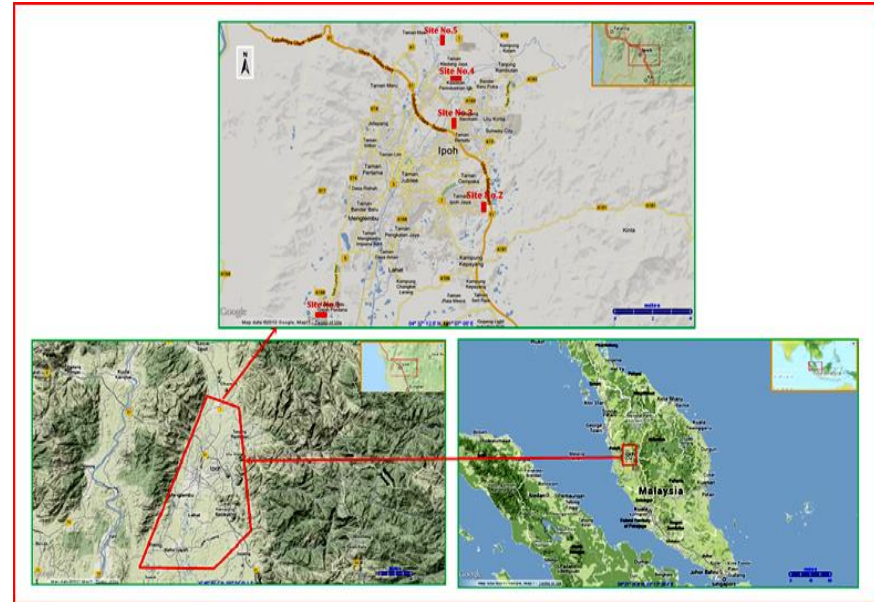

Figure 1: Google normal, Google terrain maps (2013) viewing the location of construction sites under study in (Kinta valley), Perak state, peninsular Malaysia
This study also discusses many considerations about the important elements that play major roles in the development of karst phenomena and the dissolution process in (Kinta Valley). Mining and human activities, air and water high pollution, and heavy rain developed the karst features rapidly in this tropical area of Peninsular Malaysia.

Early planning of engineering subsurface remediation techniques are needs to mitigate or minimize the potential of geo-hazard of karst features and its deposits in these construction sites over carbonate karst environmental bedrock. Furthermore, we need a new process of grouting method in the study areas of those sites such as chemical grouting techniques. Besides, they need to control of surface and subsurface water drainages. All of these plans must put into operation in these construction sites when the work is going to start at these respective sites.

\section{THE OBJECTIVES OF THE FIELD SURVEY IN THIS RESEARCH STUDY}

The objective of the field survey in this research is to:

I. Imaging the subsurface to locate evidence for near surface karst features such as voids, cavities, channel pipes and sinkholes.

II. Figure out whether clay or air-filled karst voids or cavities are present in the subsurface.

III. Calculate the Approximate depth of the marbleized limestone bedrock.

IV. Estimating the depth, shape, type, size and understand the origin of these karst features.

V. Producing the geological model of layer sediments and clarified the study area from the geophysical data.

VI. Evaluate the subsurface karst ground conditions that based on features that occurring in the intact carbonate rocks and its level and describe if that can result in potentially dangerous collapse or ground failures at construction sites that superimpose these features.

VII. Identify subsurface conditions that consequence to the reliability of any proposed future work in these sites. For example, an inactive sinkhole in-filled with thick clay. Under-compacted clay could present a critical problem, as the clays could accumulate under load, resulting in leakages all the way down to the bedrock.

VIII. Identify the best solution methods frequently used in the plan to minimize the risk of problem areas in these construction sites.

IX. The considerations about the important elements that play major roles in the development of sinkholes and karst phenomena and the dissolution process in (Kinta Valley).

\section{THE LOCATION OF CONSTRUCTION SITES UNDER STUDY}

\subsection{Construction Site \#1}

This Construction site located at Taman Batu Gajah Perdana site is a town located in the district of Kampar, about $24 \mathrm{~km}$ from Ipoh the Perak state capital. The site under study located within Kinta Valley along lebuhraya Ipoh Lumut. It's 
positioned with GPS coordinates at latitude $4^{\circ} 29^{\prime} 53.51^{\prime \prime} \mathrm{N}$ $4^{\circ} 29^{\prime} 39^{\prime \prime} \mathrm{N}$ and longitude $101^{\circ} 01^{\prime} 12^{\prime \prime} \mathrm{E}-101^{\circ} 01^{\prime} 30^{\prime \prime} \mathrm{E}$, as appeared in figure 2 .

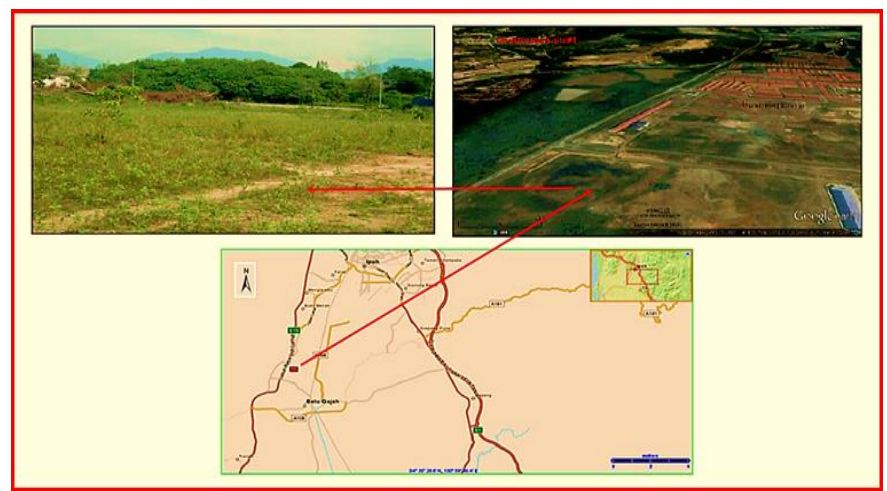

Figure 2: Location Map, Satellite images and land photograph viewing the location of construction site \#1 (Taman Batu Gajah Perdana)

\subsection{Construction Site \#2}

This Construction site located at the Gunung Rapat region, the site is visible from the express highway from Simpang Pulai to Ipoh, about $5.0 \mathrm{~km}$ south-east of the city center. The site under study located within Kinta Valley and to the south of Taman Rapat Damai, it's positioned with GPS coordinates at latitude $4^{\circ} 34^{\prime} 17.34^{\prime \prime} \mathrm{N}-4^{\circ} 34^{\prime} 25.5^{\prime \prime} \mathrm{N}$ and longitude $101^{\circ} 08^{\prime} 35.7^{\prime \prime} \mathrm{E}-101^{\circ} 08^{\prime} 29.46^{\prime \prime} \mathrm{E}$, as appeared in figure 3 .

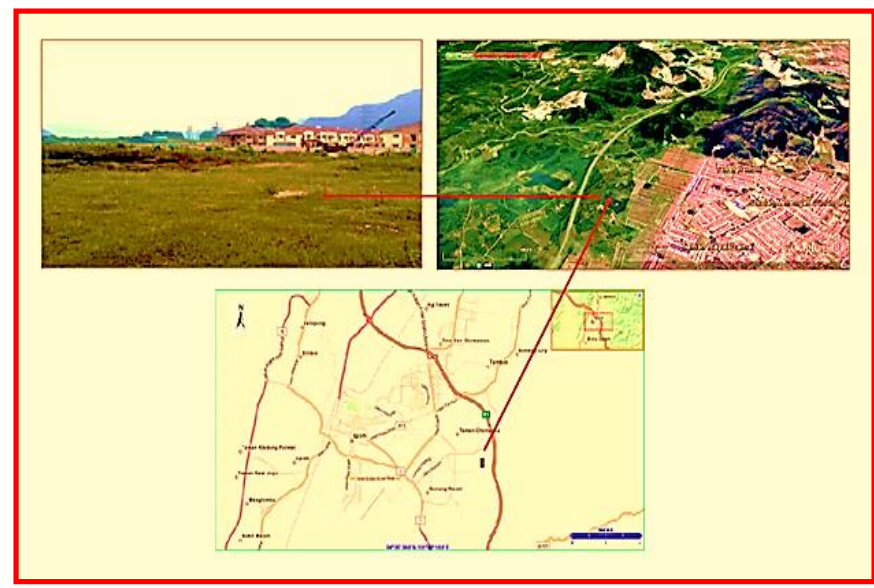

Figure 3: Location Map, Satellite images and land photograph viewing the location of construction site \#2 (Gunung Rapat)

\subsection{Construction Site \#3}

This Construction site located close to Tesco extra in Taman Tasek Indra, Ipoh city., it's positioned with GPS coordinates at latitude $4^{\circ} 37^{\prime} 32.91^{\prime \prime} \mathrm{N}-4^{\circ} 37^{\prime} 48.24^{\prime \prime} \mathrm{N}$ and longitude $101^{\circ} 06^{\prime} 57.89^{\prime \prime} \mathrm{E}-101^{\circ} 07^{\prime} 12.16^{\prime \prime} \mathrm{E}$, as appeared in figure 4 .

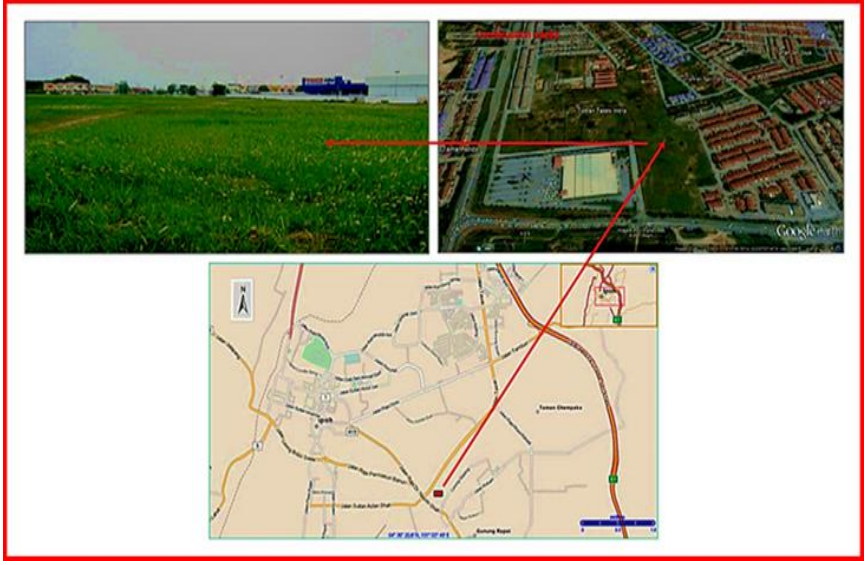

Figure 4: Location ap, Satellite images and land photograph viewing the location of construction site \#3 (Taman Tasek Indra)

\subsection{Construction Site \#4}

This Construction site located at Taman Tasek Raya, this site located to northeast Ipoh city along Kuala kangsar road near Petronas petrol station, it's positioned with GPS coordinates at latitude $4^{\circ} 39^{\prime} 04.07^{\prime \prime} \mathrm{N}-4^{\circ} 39^{\prime} 17.27^{\prime \prime} \mathrm{N}$ and longitude $101^{\circ} 06^{\prime} 21.06^{\prime \prime} \mathrm{E}-101^{\circ} 06^{\prime} 38.53^{\prime \prime} \mathrm{E}$, as appeared in Figure5.

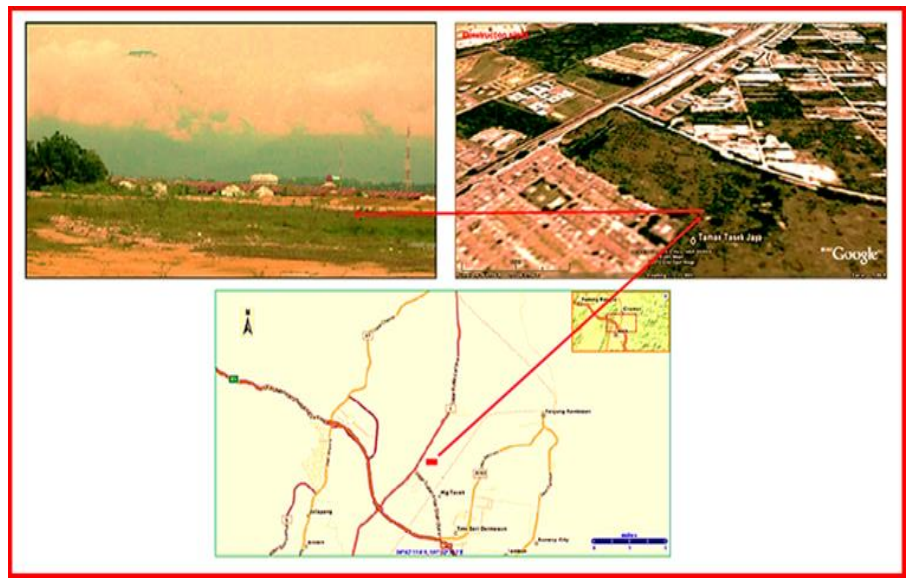

Figure 5: Location Map, Satellite images and land photograph viewing the location of construction site\#4 (Taman Tasek Raya)

\subsection{Construction Site \#5}

This Construction site located at Taman Klebang Putra - Klebang Green to the north of Ipoh city (Kinta Valley), in the West flank of Kinta valley, situated over a high topographic area and a flat terrain of marbleized limestone rocks, covered with soil. It locates to the north of the main series and east of the Kledang series. It's positioned with GPS coordinates at latitude $\mathrm{N} 4^{\circ} 40^{\prime} 47.86^{\prime \prime}-\mathrm{N} 4^{\circ} 41^{\prime} 26.96^{\prime \prime}$ and longitude E101 $05^{\prime} 55.68^{\prime \prime}-\mathrm{E} 101^{\circ} 06^{\prime} 21.6^{\prime \prime}$ as appeared in Figure 6. 


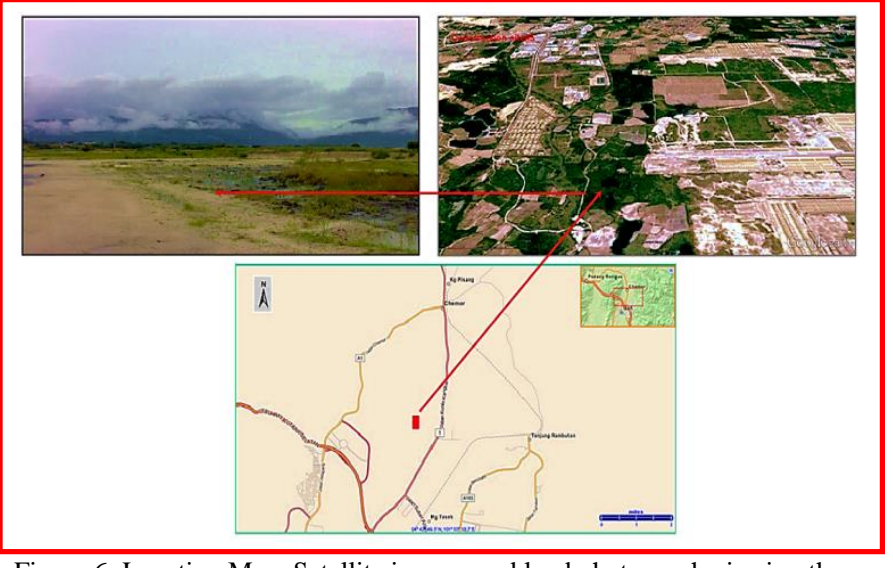

Figure 6: Location Map, Satellite images and land photograph viewing the location of construction site \#5 (Klebang Putra)

\section{The geology of the study area}

\subsection{The Limestone of Kinta Valley}

Kinta Valley, located in western Peninsular Malaysia, forms a V-shaped valley open to the south and bounded by the granitic massif of the Main Range to the east and of the Western or Kledang Range to the west. The granite that forms the mountains has been dating to the Triassic age Cobbing et al, (1992). Kinta Valley karst is made up of steep-sided limestone hills that stick out above enormous floodplain with moderate rolling hills of metasedimentary rocks.

The plain has sealed by alluvium of varying thickness and underlain by rugged and jagged subsurface of limestone platform. The limestone hills are the remnants of extensive limestone beds, which are part of large Palaeozoic carbonate platform complexes that covered parts of South-East Asia. Paleozoic limestone outcrops are scattered intermittently throughout Peninsula Malaysia.

Geologically, most of the study area is underlain by Kinta's limestone, whose origin was pinpointed to be somewhere between the Devonian to Permian periods, Suntharalingam (1968). The original limestone beds of Kinta valley, presumed to be Carboniferous, Ingham \& Bradford (1960) and Hutchison (2007) or possibly Permian in age, Fontaine (1995) have been severely eroded and karstified.

Deposits of more than 250 million years ago had buried to great depths, lithified and eventually brought to the surface by tectonic forces, presumably in the Mesozoic. The Palaeozoic limestone of the Kinta Valley has exposed to a humid tropical to equatorial climate for very long periods of time, which slowly dissolves the limestones. The hills are the only remaining visible part of the Palaeozoic limestone layers underlying the Tertiary to Recent alluvial deposits over the entire expanse of Kinta Valley and beyond.

The limestone of Kinta Valley overlay extensive younger granite bodies, which affects the texture and composition of the limestone via contact metamorphism at the time of granite intrusion, dated as originated from the Triassic age Cobbing et al (1992). Initial observations reveal that the degree of metamorphism of the limestone varies from hill to hill, from low (practically intact limestone) to high (limestone entirely turned to marble). Most of the Kinta Valley limestone has undergone contact metamorphism from Sungei Siput in the north to Tapah in the south. The less metamorphosed limestone is located in the northern part of Kinta Valley.

Active Tin mines have covered the subsurface karstic bedrocks up to $20 \mathrm{~m}$. Only $30 \%$ of limestone in Kinta valley occurs as limestone hills, while the rest are subsurface karst bedrocks, Muhammad, R. F. (2003).

Rivers from the two highlands provide an uninterrupted supply of allogenic water to the foot plain and consequently create wet and swampy conditions. Studies using Micro Erosion Meter give the assessment of limestone deprivation rates for standing water, running and under the sub-aerial condition and the values are $224 \mathrm{~mm} / \mathrm{ka}, 369$ $\mathrm{mm} / \mathrm{ka}$ and $134 \mathrm{~mm} / \mathrm{ka}$, Muhammad, R. F.(2002) correspondingly.

The surface geology of the Ipoh region has well documented by, Yin, (1976); Ingham, \& Bradford (1960). The limestone bedrock in the area rises above the alluvial plains to form limestone hills with steep to vertical slopes (mogote or tower karst). Granitic uplands are flanking the limestone of the valleys on the eastern and western sides. This geologic setting has given rise to alluvial deposits rich in tin content. Therefore, it is getting on the growth and development of the area as mining towns since the last century. The subject of foundations in limestone was one of the main subject matter in many studies. A review of borehole data by Tan (1988) showed that the depth of limestone bedrock in the Ipoh area is generally less than 20 $\mathrm{m}$. The review of the borehole data showed the size of the cavities in the limestone bedrock, were mostly $<3 \mathrm{~m}$ across.

The location of construction sites understudies in Kinta valley was viewing in the Geological map of Perak in figure 7 .

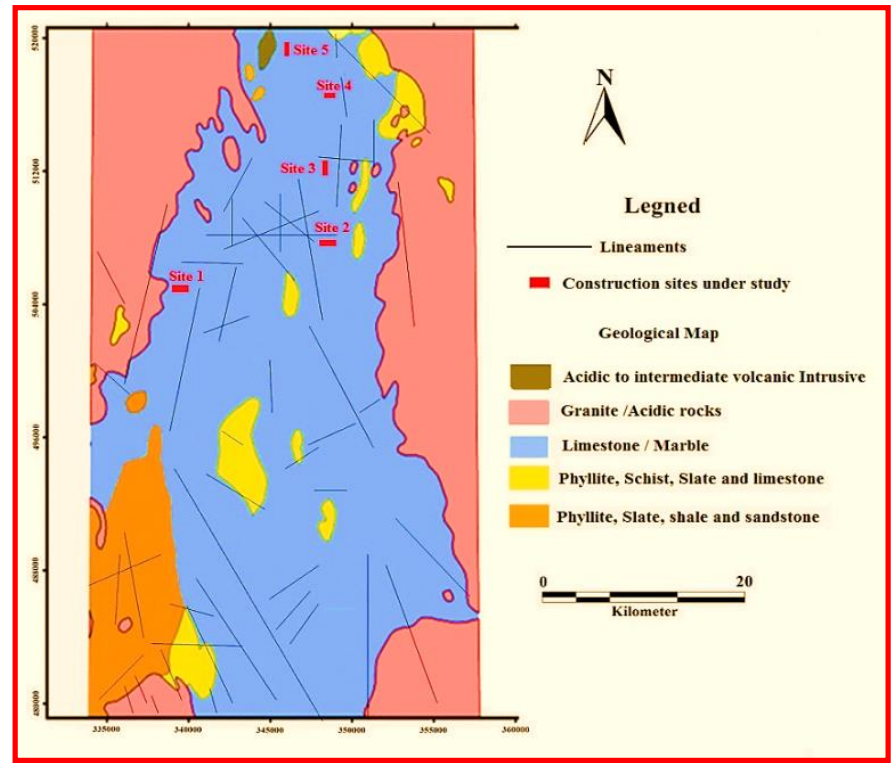

Figure7: Geological map of Perak state (Kinta valley) viewing the location of construction sites under study, by Yassin, R. R. (2013) 
Yassin, R. R. (2009;2010), applied of Electrical Resistivity Tomography (ERT) geophysical technique in several construction sites of the housing complex and shopping mall projects in Perak state, pointed out that the depth of marbleized limestone bedrock was uneven contains numerous pinnacles and gutters ranging between $3.0 \mathrm{~m}$ to more than $28.0 \mathrm{~m}$ in on-site. Furthermore, pointed out that the overburden layer has comprised of alluvium deposits and/or with tailings of mines in some locations.

\subsection{The Lithology of the Study Area}

Kinta Limestone named after Kinta Valley in Perak. It has believed that the age of the Kinta Limestone is Silurian to Middle Permian, Lee (2004).

The lithology of the Kinta Valley had made up of four main types, each producing a different landscape, they are:

1. Carbonate rocks forming Kinta Limestone in which has been going through tropical karstification to form steep sided tower and cockpit towers protruding across the enormous plain

2. Granite bodies of the Main Range and Kledang Range (series), that flanks the plain in the east and west respectively were forming rugged ranges of up to $1000 \mathrm{~m}$ above mean sea level

3. Schist that made up the rolling landscapes of the Kinta valley

4. Quaternary alluvial deposits, that has extend across the valley and form an enormous plain

The limestone in the study area is calcitic, granular and homogeneous though some dolomite and mica do occur in some places. The Silurian to Lower Devonian rocks mainly are pure cream-colored dolomite, while the lower to upper Devonian rocks consist of massive grey recrystallized calcitic limestone.

The Carboniferous rocks here mainly are thin-bedded grey recrystallized calcitic limestone with dolomitic beds and also pyritiferous black shales and argillaceous sandstone, Lee (2004). The Permian rocks of Kinta Limestone consist of grey to black crinoidal limestone overlain by impure carbonaceous brachiopod-polyzoan limestone. Besides, grey to white bioclastic and fusuline limestone overlain by biothermal limestone, Lee (2004).

The depositional environment of these Paleozoic units is in shallow marine shelf carbonate build-up with shelly flanks. The limestones found in this area are restricted and most of its metamorphosed to marble, Lee (2004).

The Kinta Valley Schist found underneath as well as interbedded with the limestone. Its age probably shorter and most of it could be older than Devonian. The limestone and schist have probably folded about the end of the Permian. These have also metamorphosed at the same time forming mainly the quartz-mica schists and the fine to medium to coarse-grained white to dark-grey calcitic marble and some minor black and reddish colored dolomites.

Most of the limestone has found beneath the general surface covered with the tin-ore bearing alluvium for which the Kinta Valley is famous. The( mogote) or isolated residual limestone hills that are seen along the valley constitute less than $10 \%$ of the actual surface limestone in Kinta Valley, Muhammad, R. F.\& Yeap, E.B. (2003).

The study area has limestone caves due to the surrounding karst formations especially the Tempurung Cave that is the largest and deepest in Peninsula Malaysia. The limestone hills extend $20 \mathrm{~km}$ north of Ipoh and $20 \mathrm{~km}$ to the south. There are many caves in these hills; cave temples are builts in some of these caves such as Kek Lok Tong Perak cave near Gunung Rapat south of Ipoh city. And others is a show cave open to the public such as Gua Tempurung near Gopeng south of Ipoh city, Salim, S. (2009)

The outcrop of limestone hills can found widespread in the eastern part of the study area. These limestone hills of Silurian to Permian age that mostly metamorphosed to marble. Limestone hills found have covered by a huge amount of vegetation. The limestone bedrock in the area rises above the alluvial plains to form limestone hills with steep to vertical slopes (mogote or tower karst). Flanking the limestone on the eastern and western sides of the valleys are granitic uplands. This geologic setting has given rise to alluvial deposits rich in tin content - hence, the growth and development of the area as (mining town) since the last century. The eastern part of the area is made up of limestone hills of Silurian to Permian age that mostly metamorphosed to marble. The outcrop of limestone hills can be found widespread in the eastern part of the study area. Most of These hills covered with a huge amount of vegetation.

Yassin, R. R., through his geotechnical survey (2010:2013), identify that the thin red cover that contains different size of granite rocks and minerals with thickness is mostly about $(5.0 \mathrm{~cm}-12.0 \mathrm{~cm})$. This thin red cover found over a layer of lateritic clay with different thickness from site to another between $(1.0 \mathrm{~m}-1.25 \mathrm{~m}),(2.0 \mathrm{~m}-5.0 \mathrm{~m})$ and with a maximum thickness $(6.0 \mathrm{~m}-9.0 \mathrm{~m})$ are mostly returns to the period of a global flood (Noah's Flood) (3300-3100) BCE.

The appearance of this thin red cover and the layer of lateritic clay are due to runoff heavy rains that have deeply eroded and washed both the highest granite ranges around the Kinta valley and then carried away by the new rivers and canyons that formed due to the erosion. A thin layer of carboniferous organic material with different thickness of $(3.0 \mathrm{~cm}-5.0 \mathrm{~cm}), \quad(8.0 \mathrm{~cm}-10.0 \mathrm{~cm})$ have seen beneath the lateritic clay.

\section{CARBONATE KARST TERRAINS}

Karst in carbonate terrains is a type of landscape found on carbonate rocks (limestone, dolomite, marble), and is characterized by a group of landforms, including an extensive range of closed surface depressions, underground drainage well-developed system, and a lack of surface streams Cooper, A. H. et al. (2011). Limestone or dolomite carbonate karst terrains are generally active and diverse in character and 
exhibit low solubility, high mechanical strength and in some cases, low ductility. The dissolution process happens very slowly; a few millimeters may be dissolved within a hundred years, which has the potential to create a cavity of $1 \mathrm{~m}$ or more across in more than a hundred years. Its highly irregular depths of bedrock, residual red clay-rich soil, and surface drainages usually characterize the carbonate karst terrains, which fade away in the underground.

Karst develops on soluble rocks, both at the surface and subsurface, due to the rate of dissolution processes that work in rapidly developing limestone rocks. This depends on a number of factors, such as the power of rainfall, availability of surface water, and its form of reviving as well as groundwater. Other factors include the distribution of soilcover, temperature and biological activity, diffusion rate, autogenic content, structural weakness and lithology of the carbonate sub-layers.

Most sinkholes in carbonate karst rocks have formed via the dissolution processes with acidic water, which occurs when rainwater absorbs carbon dioxide from the air and decomposing organic material in the soil. It becomes more acidic and penetrates into the cracks, which dissolves the rocks. Carbonate karst can be a part of the global carbon cycle, in which carbon is exchanged between the atmosphere, surface and underground water and carbonate minerals. The dissolution of carbonates via the presence of acid in water combines the carbon derived from the rock and from dissolved $\mathrm{CO}_{2}$ as aqueous $\mathrm{HCO}_{3}$.

The deposition of dissolved carbonate minerals has accompanied and usually generated by the release of some of the carbon as $\mathrm{CO}_{2}$. When the bedrock is water-saturated, the dissolution continues along the bedding planes through the horizontal cracks between rock layers and joints, or fractures in the rock itself. These conduits enlarge over time, and the water moving by means of a combination of gravity and hydraulic pressure will further enlarge the conduits via a combination of dissolution and abrasion of the surrounding rocks. The communication varieties among chemical, physical and biological processes have a broad range of geological effects, including dissolution, precipitation, and sedimentation and ground subsidence. Diagnostic features such as sinkholes (Dolines), sinking streams, caves, and large springs are the result of the dissolution action of circulating groundwater, which possibly dispersed to entrenched effluent streams.

Initially, most of the underground water moves by laminar flow within narrow fissures, which gradually become enlarge at or below the water table to form subsurface caves. Once a certain conduits-size threshold has exceeded, which is typically around 10 to 20 millimeters, the flow becomes turbulent. The caves contain a variety of dissolution features, sediments, and speleothems (deposits with various forms and mineralogy, chiefly calcite), all of which may preserve a record of the geological and climatic history of the area, surface and subsurface, due to the solution and associated processes.

Most of the sinkholes have created on soluble carbonate rocks (marble, limestone, and dolomite) because of greater dissolution related to the difference in composition. The sinkholes developed at both the surface and subsurface are due to the solution and associated processes.

\subsection{The Karst Hazard}

The Karst hazards are an important example of natural and human-induced hazards in karst areas, connected with the nature of karst. Many hazards related to man-made structures can be associated with the type of bedrock

The natural hazards that resulting from the introduction of human activity, natural processes and events. They occur in areas with soluble rocks such as carbonates mostly limestone, dolomite, and chalk A geologic hazard is a naturally occurring geologic condition that may result in property damage, Bradley, P. B. (2003). It is a threat to the safety of people. The natural processes and events and the effective underground drainages the potential to create loss, Smith (2001), or a source of danger, and the possibility of loss or injury, Fema (2001).

The presence of faults and other earth processes that occur such as earthquakes, landslides, shrink-swell soils, flooding that causing more damage is the most effective in the economic loss yearly.

Four geologic hazards are associated with karst, two common karst-related geologic hazards:

-The cover layer collapse sinkholes.

-The sinkhole flooding cause the most damage to buildings.

-The karst hazard is relatively high concentrations of radon, sometimes found in basements and edges spaces of houses built on karst.

-Finally, the karst aquifers makes the groundwater exposure to pollution and this may considered as type of geologic hazard.

Foundations over carbonate karst environment have been of supreme apprehension to the geoengineers over the last two decades. These problems attributed to the various solution features that are inherent and especially well developed in tropical karst regions. The problem of foundations in carbonate karst regions namely; the high pinnacle bedrock topography, the extension of solution channels and cavities, the thin arches or roofs over cavities, the collapse of weak soil zone above the carbonate bedrock, Ting (1986), Tan; Komoo,(1990).

Furthermore, the overburden zone consists of many varieties of appearance, young and old overburden soils, tailings of mines. For that circumstance, the problems found in this zone. The collapse of the limestone unusually occurs damaging in buildings with little warning, because of the groundwater moves rapidly from place to place in large cavern passageways, pollution and contamination of water supplies is a serious threat, Strahler (1981).

Several types of features observed in the clayey soil over carbonate karst environment in one of the construction sites under study due to the effects of heavy and long-time rain full display in the land Photographs figure10. 


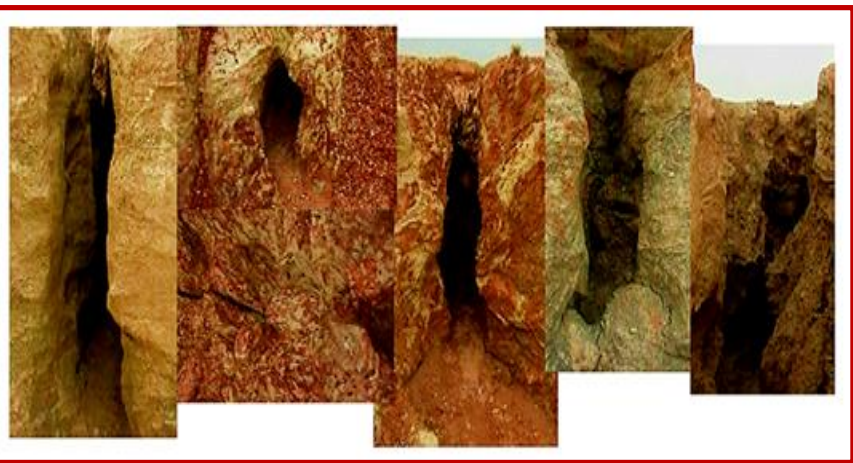

Figure10: Land Photographs viewing several types of features observed in the clayey soil over carbonate karst environment in one of the construction sites under study due to the effects of heavy and long period of rain full

In addition, the Karst regions impose some unique environmental hazards to humans, particularly urban areas where heavy structures built over cavernous limestone. The geotechnical engineering and environmental problems are increasing rapidly due to the presence of cavities and irregular buried of subsurface karst limestone.

\section{THE PROBLEMS FACING THE GEOENGINEERS AND GEO ENVIRONMENTAL ENGINEERS IN CONSTRUCTION PROJECTS OVER THE CARBONATE KARST REGIONS}

Carbonate karst terrain is one of the most complex ground conditions for any construction project planers. The geoenvironmental, geological and civil engineers in Perak state facing numerous problems in constructing the structures that situated over marbleized and dolomitized limestone karst environments, due to various class of karst solution features such as sinkholes, caves, karst voids cavities, channel pipes, depressions, conduits, internal drainages system, solutionwidened joints, intensely fractured zones and faults. These features directly exert a negative impact on the use of the land for construction and the design of shallow foundation structure projects. Furthermore, it can also indirectly have the potential to cause catastrophic damages in the near future perhaps many years after the project has ended. The subsidence damages was result through the construction works will cause massive losses which maximize the project overall cost leading to enormous financial costs, to the developers and the lands.

The construction project planer stagger upon many factors that should be consider while designing any construction project in any site over carbonate karsts environment. Such as the depth to the karst features, the lateral dimension, the thickness of overburden layers, the drainage system and the hydrogeology of the area, Karst landforms and its development and the class or level of the karst features.

To avoid any subsidence in the construction sites over carbonate karst regions, the project manager, the geological, geoenvironmental and civil engineers must obtain in their consideration while designing the structures, the weight of structures overloading the ground surface and placing the most of the significant constructions with heavy loads out from the problem areas of the site. Many problems facing civil engineers while founding the structures over carbonate karsts region are most likely the difficulties in controlling the surface and groundwater in the karst region, controlling the contamination of groundwater, loss of water from dam reservoirs, fall down the covering roof of the voids, the subsidence or collapse of soil-cover sinkholes.

Usual methods of site exploration in carbonate karst regions such as office studies, site investigation, borings, testing the pits, have their individual advantages and disadvantages and none of these methods is $100 \%$ accurate. Therefore, they should be customized for each project according to the accessible financial statement and the undertaken risk. To obtain as much information as possible, it's must including of geological and topographical maps, Arial and satellite photographs, hydrogeology reports surface and groundwater, the records of water well and reports to notify the decree of dissolution or fracturing of the rock. The geologic and topographic maps, Arial and satellite photographs use to indicate the continuation of caves, sinkholes, drying streams and faults in performing the site evaluation. Necessary steps should take for identification and investigation of subsurface karst features by application of a geophysical field survey technique to put in consternation of the prediction and mitigation of the risk of these karst features in construction sites.

The events of carbonate rocks collapse are extremely rare. In order to protect the construction process, the foundation concepts on the carbonate karst areas must be designed within the limestone formation below weathered and cavern zones that considered safety. During foundation work, small cavities only came across within the zone of constructions. The foundation's design became hazardous only if the zone of construction with a heavy load is above the roof of caves, Waltham (1989).

The zone of construction became hazardous if there loading over the cavities or on the rockhead of irregular subsurface topography of carbonate bedrock. Collapse or subsidence sinkholes are one of the most frightening geologic hazards threatening the constructions, due to the differentiation of settlements construction's foundation in the karst development area at Peninsular Malaysia. The issue of the probable presence of solution features such as sinkholes must be carefully considered while making land-management decisions, including decisions for protecting the water supply, locating of septic systems and placing of waste disposal facilities.

Foundation treatment over carbonate karst environments bedrock has conducted and has been used in several worldwide projects and includes, engineering fill, geosynthetic materials, concrete filling, and low-pressure cement grout injection. Caves under the newly constructed settlement areas can be treated by using of high slump concrete filling.

The first engineering classification of karst ground conditions present by A. C. Waltham and P. G. Fookes, (2005) which describe simplified guidelines to the potential 
variation in landforms and the characteristics of the morphological features and ground cavities that possibly come upon in civil engineering works on karst terrains. This classification divides the Karst terrains in planet earth into five classes. The five classes illustrate the karst terrains in terms of the difficulty and complexity that come across the foundation engineers. In these classifications, the carbonate karst regions in Malaysia classified as extremely karst terrains.

\subsection{The Karst Features That Affected the Engineering Projects}

Carbonate karst environment could provide specific problems for all classes of engineering projects, from the construction of housing complex to major roads, bridges, highways, tunnels, reservoirs, and mining. These problems mostly arise for many reasons, some of the problems it is of predictable occurrence, and some others are non-predictable occurrence. The non-predictable karst feature in carbonate bedrock associated with variable overburden soil properties, which leads to a variety of geological engineers and geoenvironmental engineers' problems and hazards Yeap, (1985). Gue, (1999) discusses some of these common problems.

The non-predictable manly occurrence from:

- The developed collapse only appears when the topsoil removed

- The depth and extent of underground cavities may lead to insufficient foundation support

- The great variability in the depth of subsoil may lead to irregularity in the type and depth of excavation required and the expected amount of drilling or blasting

\subsection{The Problem of Foundations in Carbonates Karst Environment}

The Problem of Foundations in Carbonates Karst Environment Namely:

The highly pinnacle bedrock topography

The extension of solution channels and cavities

The thin arches or roofs over cavities

The collapse of weak soil zone above the carbonate bedrock Ting,(1986) ; Tan and Komoo,(1990)

\subsection{The Greatest Karst Features That Affected the Engineering Projects}

The greatest karst features that affected the engineering projects are:

\subsubsection{The Cavities Hazards}

The cavities formed through dissolution processes in limestone rocks through:

- The mining and human activities

- The Air high pollution

- The water high pollution

- The heavy rainfall
All of these elements developed the cavities rapidly, and that will pose problems if the roof of the cavities is not sufficient strength to support the foundation that resting over them. Especially, if it partially filled or empty cavities.

Geoengineering and geoenvironmental problems are increasing rapidly due to the presence of cavities and irregular buried karst limestone in the subsurface. Cavities in the limestone bedrock are of major concern to foundation engineers. It is occurring at various depths, in multi-levels, with various sizes and thicknesses. The investigation of cavity sizes based on borehole data in the Ipoh area showed that they are mostly $<3 \mathrm{~m}$ in thickness. Ting, (1985) \& Ting et al., (1993) concluded that the most common cavity size is $1 \mathrm{~m}-3 \mathrm{~m}$. However, large cavities $>3 \mathrm{~m}$ can still be come across at certain sites

Consequently, the detection and determination of the detailed configuration of the cavities and cavity system at a particular construction site are major efforts in a site investigation program, in particular where high-rise buildings are being planned and constructed. The (2D) Twodimensional geophysical models have used to represent and interpret the complicated nature and extent of the cavities and the bedrock profile.

A recent high-rise buildings and housing complex projects in the Ipoh area, great efforts put in to detect the cavities in the limestone bedrock by using geophysical techniques. Numerous cavities, some at multi-levels have detected. The formation of cavities in the limestone bedrock related to the fluctuations of the groundwater level.

These cavities developed mostly within the zone of groundwater level fluctuation, and it is reasonable to imagine that deeper down below the zone of active groundwater fluctuation, the cavities formation would be limited. The exposures at the Quarry (bedrocks) seem to support such an idea that below an influenced depth the limestone bedrock is become massive and although jointed, without cavities or other solution features.

The Collapse of underground Cavities only became existence when the topsoils are removing displayed in figure 11.

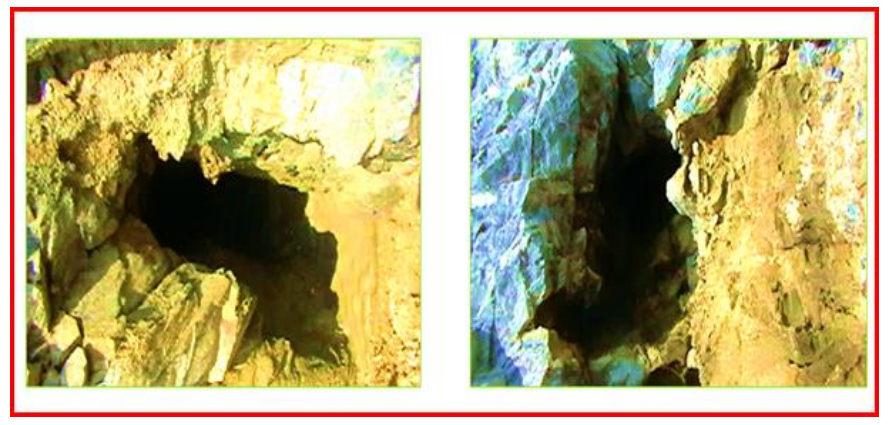

Figure 11: Display the collapse of underground cavity, only became existence when the top soils are removing

Voids are underground open spaces that may be of natural or man-made origin. Natural structures include caves, dissolution and collapse cavities in soluble rocks, cambering fissures or gulls, open fault cavities and lava tubes. Man- 
made voids include all the different types of mines, habitation, religious and storage spaces, military excavations, tunnels, and shafts. From time to time, is a collapse of a portion of bedrock above a void, could happen, a foiba or a sinks could open, this may be sheer his vertical opening into a cave, or a shallow depression. The near to the surface large voids have observed in many construction sites, figure 12 .

The Construction in karst areas includes the risk of come upon voids in the underlying material. Structures built above voids can experience significant settlement and extensive structural damage. In the most severe cases, the voids may open to the surface, cause catastrophic failure of the structure, and endanger the public. For commercial projects with tight deadlines, identifying potential subsurface voids early in the pre-development stage is critical in being able to provide time for further assessment and for remedial activities to be employed.

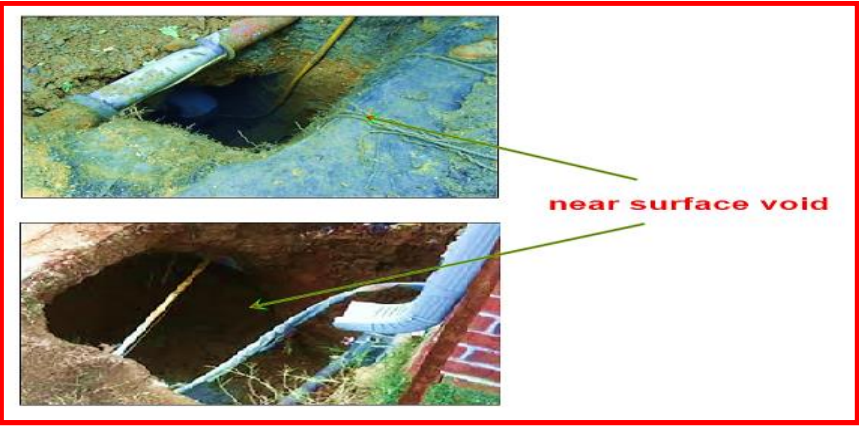

Figure 12: Near surface large voids are observe in construction site

In the recent high-rise buildings and housing complex projects in the Ipoh area, great efforts put in to detect the voids in the near- surface or upper layers over limestone bedrock by using geophysical techniques. Numerous of these voids have detected.

\subsubsection{The Rockhead Pinnacles Hazards}

Pinnacles are cones or pillars of limestone or marblized limestone or marble formed due to the dissolution processes of the surrounding carbonate rocks. Pinnacles that covered immediately by soft or loose overburden layers pose great challenges to the geological engineers to confirm a suitable seating of piles on the rockhead Pinnacles.

Generally, the difficulty involve of opening hole for a driven of concrete bearing piles or bored piles in the rockhead Pinnacles. Rockhead Pinnacles partially exposed in the study region (Kinta valley) display in figure8-3.

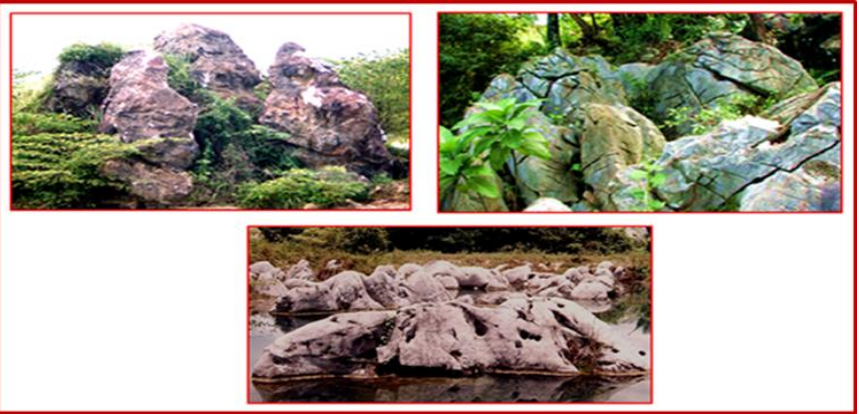

Figure 13: Display the Rockhead Pinnacles partially exposed in the study region (Kinta valley)
Foundations over karstic rock head Karst of class kI provides rock head that is sound except for unpredictable isolated fissures or shallow cave that may require response during construction. Rock head of karst (class kII) generally creates only minor problems. Installation of piles may require longer elements for some parts of a site, Statham and Baker, (1986), and reinforced ground beams can design to span small new ground failures Mishu, et al.,( 1997).

A road or light structure can carry safely on the soil over a deeply rocked pinnacle of karst class $\mathrm{kV}$, where drainage is not disturbed, though geo-grid reinforcement may be appropriate. Rock head pinnacles with $50 \mathrm{~m}$ high in some tropical karsts offer dreadful ground conditions for heavy structures that demand to found on bedrock (Bennett, 1997). Each pile location requiring its own ground investigation and the designs must modify to high-class ground conditions as it exposed by excavation. In a site with karst classes, kIV and $\mathrm{kV}$ generally require that structures are founded on sound limestone by driven piles down to rock head Pinnacles or covering between sound pinnacle tops Brink, (1979). Driven piles maybe curved deflected or poorly founded on unsound pinnacles Sowers, $(1986 ; 1996)$. In that case, the bored piles are preferred and each pile tip probed to ensure lack of voids beneath, and narrow unstable pinnacles may require assessment by probes splayed $15^{\circ}$ from the vertical. Adding $30 \%$ to the mean rock head depth as a guide for planning will indicate the mean final length of the end-bearing piles needs Foose \& Humphreville (1979).

\subsubsection{The Collapse of The Weak Soil Zone Above Carbonate Karst Bedrock Hazards}

Subsidence described as a widespread phenomenon associated with the sinking of the ground. The vertical movements ranged from collapse to slow settlement. Generally, subsidence can occurrence for many reasons:

\section{The removal of subsurface fluids}

Drainage or oxidation of organic soil

The to surface or cover layer collapse into natural

The excavated of subsurface cavities had taken place

The occurrence of soft mining clay gunk when housing and roadwork projects are carried out due to the consolidation of the underlying gunk of clay upon loading and proceeding at slow rate.

Subsidence due to the settlement of the ground surface in one construction site over the karst region in study area present in figure 14

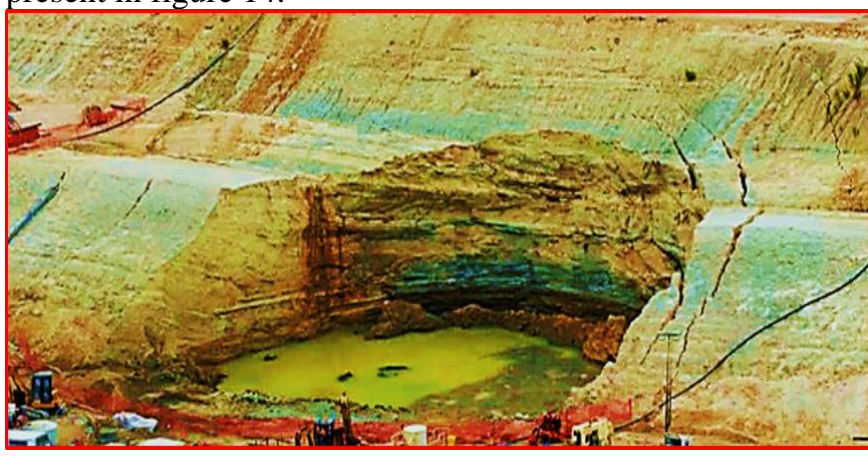

Figure 14: present subsidence due to the settlement of the ground surface in construction site over the karst region in study area 
Furthermore, the subsidence of the ground surface in the construction site occurring due to heavy rainfall period. The settlement of the ground surface due to heavy rainfall period in the construction site over the karst region in study area present in figure 15 .

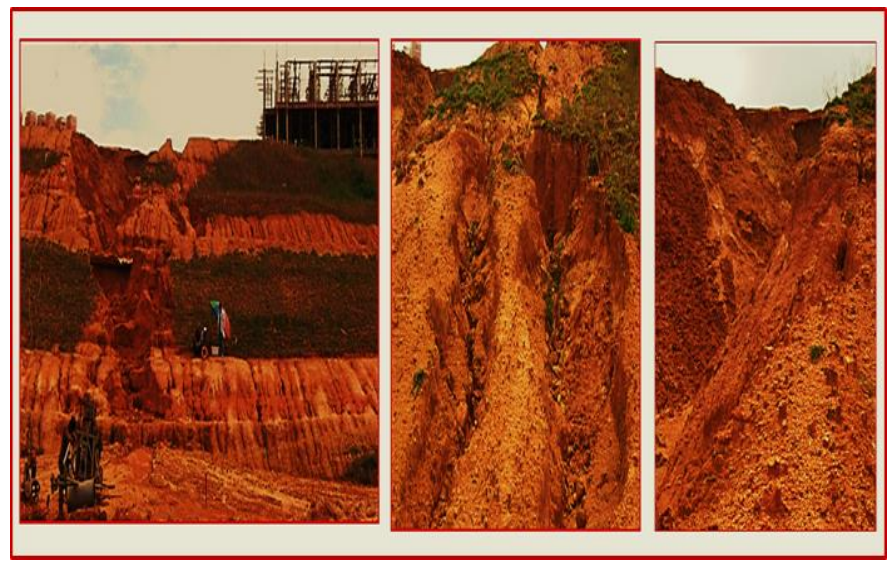

Figure 15: present subsidence due to heavy rainfall period in construction site over the karst region in study area

\subsubsection{The Sinkhole Hazards}

The sinkholes are the main crux of the geo-hazard that issue in a limestone formation due to natural erosion processes. Sinkholes mostly created on soluble carbonate rocks (limestone, dolomite, dolomitic limestone and marbleized limestone). Sinkholes developed at both the surface and subsurface due to the dissolution related to the difference in composition, associated processes, and posed many problems, which classified by Waltham, A.C. \& Fookes, P. G. (2003) into six types. In this study will present the type of sinkholes have exposed in the study area including, the dissolution sinkholes type, which formed due to slow dissolution processes. In addition, the subsidence sinkholes type, that formed due to soil cover or cover layer subsidence within this karst region. Those, normal features in this karst region have developed over the geological timescale.

The formation of the sinkhole is usually very sudden and unpredictable. As such, its consequences can be catastrophic. Consequently, several reports and documentation about sinkholes collapse or swallowing parts of the roads and the houses or facing civil structures works are too widespread. The dissolution sinkhole as an old feature it maybe reaches about $1000 \mathrm{~m}$ across and $10 \mathrm{~m}$ deep. The other type is a collapse sinkholes that formed due to the failure and collapse of the limestone covering over a large cavern or over a group of smaller caves. Subsidence sinkholes (both dropout and suffusion) that formed in soil cover within karst regions are created due to the rapid failures of soil due to the downward percolation of water and many occur during heavy rainfall events, (Hyatt J.A. \& Jacobs P.M., 1996) which are the major sinkholes hazards to civil engineering works.

Most of these types have formed in Malaysia that is the major sinkholes hazards to construction projects. The most foundation problems occur where soil zone with a thickness of about (3-10) m overlying a fissured rock head.

In Frequent, the large failures are known in soils zone that happened with thickness about (30- 50) m, Jamal S.E. (1986). Construction delays and stability problems have caused by sinkholes appearance in the site, which may increase the cost of the project some time due to the possibility of wall cracking, collapse of some buildings' foundations, or subsidence and cracking on paved roads.

Extensive studies for the sinkholes formations were done by Yassin, R.R (2009 - 2013), have shown that sinkholes are likely to form in regions mostly located in the southern part of the western belt of limestone hills and an east-west line across Ipoh. Within the region of carbonate karst environment, extended from Tapah city, which located in the south of the valley, until Kuala Kangsar city, which located in the north of the valley. In the cities such as Pulai, Gopeng, Rapat, Batu Gajah, Kampar, Ipoh, Taman Tasek, Putra Klebang, and Klebang Restu (Kinta Valley) Perak state. All of these cities in over carbonate karst environment are former tin mines. Some of these sinkholes spotted and marked in satellite images and found distributed within two zones.

The first zone has to trend from the south to the northnortheast of the valley. However, the second zone has trended from the south to the north-northwest of the valley. In addition, the study shows that the mining and human activities in the Perak region, air and water high pollution, and heavy rains led to soil erosion and subsidence, after the development of the karst features rapidly in this tropical area of Peninsular Malaysia. Therefore, sinkhole found development is more common in the pure limestone with a high content of calcium carbonate over $95 \% \mathrm{CaCO} 3$. While the more dolomitized karst areas with a high content of magnesium carbonate $40 \% \mathrm{MgCO}_{3}$ are less level to the sinkhole development.

The natural of Karst features in the carbonate bedrock such as severe or uneven pinnacles topography, cavities and linear trenches all contribute or provide the geologic settings for the development of sinkholes. Man-made factors or activities such as changing the groundwater level by pumping for watering the farm and deep excavations to open-cast mining can generate the formation of sinkholes, the occurrence of rockfall, soil erosion, and subsidence. In addition, excavations of the lands, removing the trees for construction projects works. Therefore, it is reasonable that sinkhole problems have become the common interest not for geologists and engineers only, but also for city planners and even enterprise or project managers.

This is a common phenomenon in carbonate karst areas, especially areas with loose and non-cohesive sands over limestone bedrock. The developments of sinkholes are related to the underlying highly irregular limestone bedrocks with its associated subsurface Gutters and Trenches. The collapse of soil zone above the cavities in the limestone bedrock, describe as subsurface erosion of mine tailings, and lowering of the groundwater table sometimes causes by dewatering and excavation activities during mining and construction.

Sinkholes that occurred in the Ipoh region have 
documented by Shu, (1982; 1986). It's believed that these sinkholes related to the dewatering of deep opencast mines in the region. Many of these sinkholes are small with diameters of several meters, vertical sides and with variable depths. Several sinkholes could occur at any site, following the trends related to subsurface linear trenches controlled by fractures such as major joints or faults in the limestone bedrocks.

The recent spate of sinkholes, totally about 40 in number, appeared in an area south of Ipoh within the Kinta Valley soon after the major earthquake off Sumatra on 26 December 2004. These sinkholes correlated with trembles from the Sumatran earthquake. However, the geologic conditions somewhere these sinkholes developed, namely limestone bedrock overlain by mostly sandy mine tailings, were such as to have a high potential for the formation of sinkholes and the earthquake vibrations supplied the triggering factor to initiate their development. It has reported that the same earthquake also triggered a sequence of sinkholes in Thailand, Chow. Sinkholes formed due to earthquakes discovered in the karst region to south Ipoh city (Kinta valley) shown in figure 16.

Rainwater or polluted groundwater can dissolve via its acidic solution the limestone rock within a certain period. The penetration of groundwater through weak zones in the limestone bedrock will developing channels that will act as passages for water together with the loose sand to flow or move. The present cavities or voids in the limestone will develop, an empty space in the layer where will occurred.
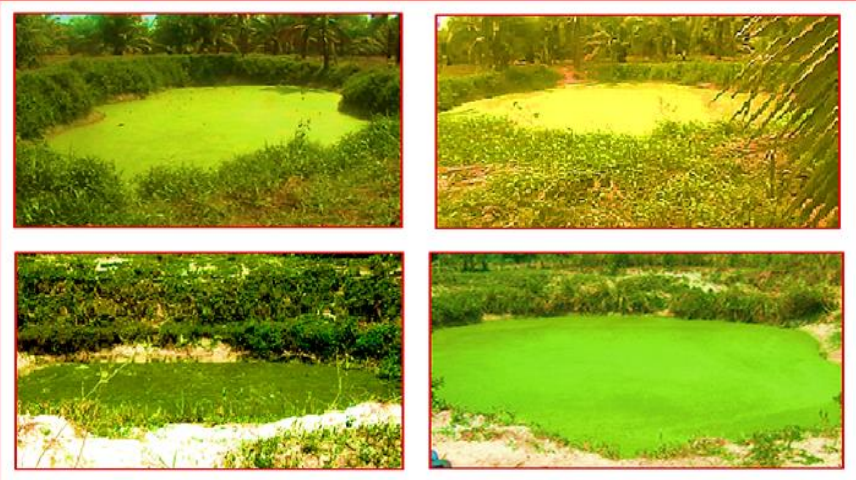

Figure 16: Display sinkholes formed du e to earthquakes discovered in the karst region in south Ipoh city (Kinta valley)

The continuous process will reach a critical stage that the roof of the space will no longer support the weight of the overburden. This will result in the occurrence of sinkholes or cavern. The lowering of groundwater level can also be interrupted by the arching balance mechanism that supports the overburden soil due to construction excavation dewatering or due to dynamic loadings from sources such as earthquakes and railway lines.

\subsubsection{The Soil-Covers Collapse sinkholes Hazards}

Most of the Perak regions discovered within soilcovers collapse sinkholes that these locations are common for geologic characteristics of groundwater $15.0 \mathrm{~m}$ to $20 \mathrm{~m}$ level below the surface. The overburden layers of porous material as residual silt-clay soils have $9.0 \mathrm{~m}$ to $15.0 \mathrm{~m}$ thickness. Then highly weathered condition of underlying marbleized limestone or dolomitize bedrock. The location and positions are close to active soils cover collapse sinkholes. In some areas, it found that the groundwater level is deeper below the surface than the soil covers collapse sinkholes due to thick sequence of mine tailings over the overburden layers of soil, clay, and silt over karst marbleized limestone bedrocks.

These factors must be recognized, calculate and standardize in order to be utilized in an analytical method which includes measuring and normalizing the geological outcrop patterns, identifying the groundwater that interconnect the karst features, structural features of the area. The sudden appearance of the soil cover collapse sinkhole initiated, when the development of small voids at the depths of a few meters in soil or unconsolidated cover overlying karst bedrock.

This enlarged by a loss of cohesion and loading of the arch-forming material caused by either saturated soil by rainwater precipitation or by rapid draining of submerging void. In addition, increased pore pressure. This results in a loss of strength in the arch and the arch becomes too thin to support its own weight. Then the underside of the arch will be cracking down into the void.

Clayey Soil when presenting on the building foundations in the construction sites can cause foundation problems if the majority of the layer's contents of clay soil. Due to increases or decreases in the water content, that affected in slowly change in volume of clay soil, after a season of heavy and long- time rainfall. Several types of features have observed in the clayey soil in one of the construction sites under study.

The formation or emergence of a sinkhole is usually very sudden and unpredictable. As such, its consequences can be catastrophic. Therefore, it is reasonable that sinkhole problems have become the common interest for not only geologists and engineers, but also city planners and even enterprise or project managers.

\subsubsection{The Sinkhole Flooding Hazards}

The sinkhole flooding in karst terrain forms part of the natural karst hydrological system, (Bradley, P. B, 2003). It occurs during periods of strong rainfall through short duration when the quantity of storm water runoff flowing into sinkholes exceeds their outlet capacities, and they cannot drain into underlying caves fast enough to prevent ponding.

When the capacity of the cave system to transmit storm water is exceed, and the water must be stored temporarily in sinkholes since it cannot be stored on floodplains like surface streams. Once a high water table results from a backwater will effect on ground water flow caused by surface and subsurface streams at flood stage (Crawford, 1984). Sinkhole floodplains store floodwater until the natural drainage system accepts the excess runoff.

Many land planners be unsuccessful to recognize sinkhole flooding and sinkhole floodplains because they do not occur along understandable flood prone areas like permanent stream courses (Kimberley, 1993). In addition, 
often miscalculate the actual amount or degree of sinkhole floodplains.

\subsection{Slump Zones Hazard}

One of the unique features of the limestone bedrock in karst terrain is the occurrence of the slumped zone or collapsed of the weakness zone of soil that immediately above the limestone bedrock surface in Ipoh (Tan, 1988).

This phenomenon is now well recognizing in Malaysia. The formation and identification of this slumped zone has discussed by (Tan \& Ch'ng, 1986).

(Tan ; Ch'ng, 1986) the formation is either due to subsurface erosion as a result of overburden slumping into cavities in the limestone or residual weathering of ancient karst features recognition of the presence of the slumped zone is via its very low S.P.T.N values of $\sim(0)$ zero are recognition of limestone bedrock surface is approach or low cone resistance. Overlying the slumped zone can be much stiffer soils with $\mathrm{N}=(30-50)$ or more, Similar occurrences have reported in other limestone areas. Slumps zone can see in about two thirds of the way up on the cliff face. In addition, series of thicker beds, up to $2 \mathrm{~m}$ thick, within a sequence of thinly bedded limestone in Chemor, Perak state, display in figure 17.

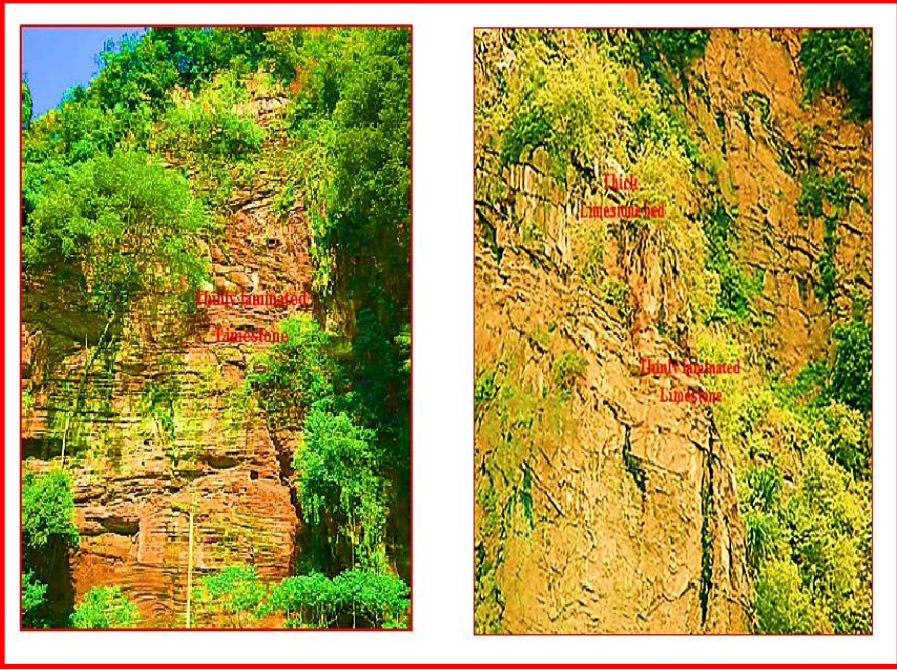

Figure 17: Slumps zone can see in about two thirds of the way up on the cliff face. In addition, series of thicker beds, up to $2 \mathrm{~m}$ thick, within a sequence of thinly bedded limestone in Chemor, Perak

\subsection{Steeply Inclined Bedrock Surfaces}

Steeply inclined bedrock surfaces in limestone posed significant difficulties for piled foundations such as poor endbearing resistance and pile breakage during installation of driven piles, especially for bedrock with adversative geological features such as vertical joints.

Vertical joints and cavities exposed in Ipoh limestone and marblized limestone rocks in Kinta valley, Perak state shown in figure 18 .

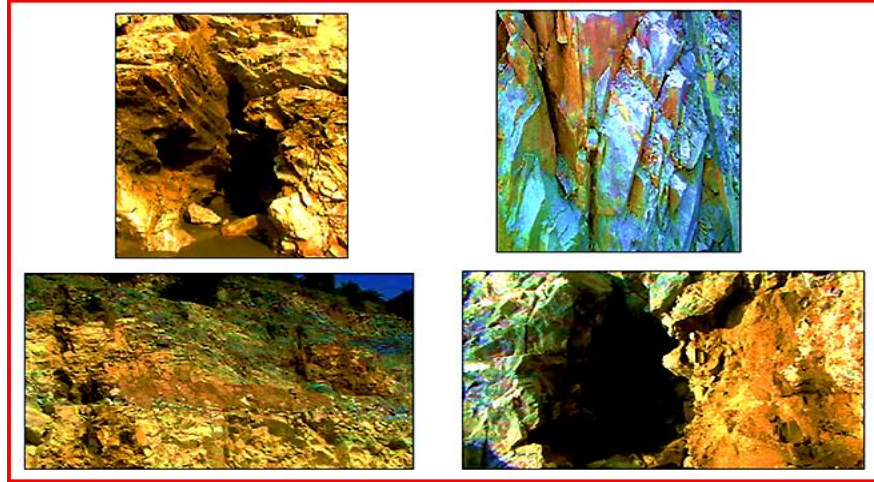

Figure 18: Display the vertical joints and cavities that exposed in Ipoh limestone and marblized limestone rocks (Kinta valley)

\subsection{The Landslides Hazard}

Landslides are a common problem in Ipoh regions. In range with landslides are associated with mining and exmining ground that are highly subject to landslides due to the presence of the loose sands and soft slimes/clays in the mine tailings areas. The method of mining using gravel pumps with hydraulic jets and its various associated non-natural landforms such as tailings bund, mining ponds, etc.

In addition, increase the potential for landslides is the rapid dewatering of mining ponds that can trigger slope failures leading to the destruction of adjacent properties and infrastructure (houses, roads, etc.), (1987a).The landslide destroyed a row of newly completed double stores linked houses builds on the bank of the ex-mining pond, which was being dewatering. A significant number of major landslides associated with mining in the Ipoh area and another state) in 1980 encouraged me to set up a committee on mine safety to study the problem.

The report through the technical subcommittee, (1982), contains conclusions and recommendations with respect to mine slope stability. The nature of the slides has mostly flowed slides associated with soft slimes/loose sands (tailings), obsolete rule-of-thumb methods had been used to design mine slopes. In addition, geotechnical investigation and design of mine slopes were insufficient and need form geotechnical engineers a founded design. Another common occurrence of landslides is associated with hillside or hill slope development, in particular in the area where many housing projects, condominiums and associated infrastructure located on hilly terrains.

Slope failures involved either cut slopes or fill slopes, in individual fill slopes. Materials involved either the residual soils/weathered rocks derived from granite, quartzite or Phyllite, or fill materials derived from the excavation of these soils and rocks. It is reasonable to conclude that colluvial deposits are also complicated. Tan, (1987b; 1988c) has documented characteristic examples of slope failures associated with hillside development. The incidents of landslides problems associated with hillside or hill slope in Ipoh regions display figure 19. 


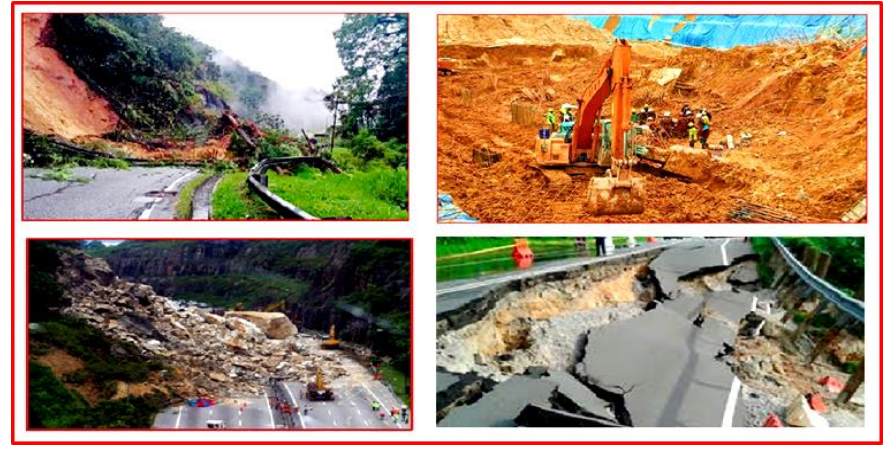

Figure 19: Displays the incidents of landslides problems associated with hillside or hill slope in Ipoh

\subsection{The Rock Falls Hazard}

Kinta valley where Ipoh is located includes forty (40) limestone hills. Their sub-vertical limestone cliffs range in heights from $(60-600) \mathrm{m}$. Incidents of rock falls are quite common, and have, at times, resulted in loss of life as well as damage to properties. (Shu \& Lai ,1980), (Shu et al. ,1981), have documented an major rock fall at Gunung Cheroh, Ipoh, the rock fall involved the collapse of the entire cliff face as a single slab measuring some (33) $\mathrm{m}$ in length and with weighing of $(23,000)$ tones. It resulted in 40 human losses of life and as well as numerous animals.

The limestone hills in the Kinta Valley have been subjected to detailed field mapping to delineate sites of past rock falls and potential future rock fall sites, Tan (1988a), Both structural features such as joints, faults, bedding planes and solution features caves, cavities, solution channels, basal under cuts, overhangs were mapped. The survey of rock falls indicates that:

a. The process of rock falls represents a natural process for all the limestone hills regardless of size it slowly reduces the limestone hill until its ultimate disappearance from the ground surface.

b. The rock falls structurally controlled by joints, faults or bedding planes, with the sub-vertical structures more likely to give rise to rock falls.

c. The solutional features, such as basal grooves or under cuts and solution channels can contribute to rock fall occurrence.

d. Stalactites, which are usually comes upon, hanging down from overhanging cliff faces can also be a source of rock falls, even though they are minor in size.

e. The quarry blasting, is a common contributory or triggering cause of rock falls in the area - many incidents of rock falls appear to be associated with quarry operation/blasting.

For the mixed development of Tambun and the suburban area of Ipoh, a similar survey of the limestone cliffs was conducts to assess the stability of individual limestone cliffs and to guide the developments around the hills. The results of this survey indicated to the developer where there are safe zones to develop, and where there are hazardous zones to avoid Tan, (1998).
Detailed surveys of limestone cliffs are necessary to allow urban development near these limestone hills, in contrast to the approach adopted by the Department of Minerals and Geoscience, Malaysia, which requires a safety buffer zone of $2 \mathrm{x}$ height of cliff where buildings should not be positioned. This requirement disinfects large regions of land around limestone hills with regard to development, which may not be applying where land is at a premium for urban development. The recent assessment of the limestone cliff stability was conduct for housing and water tanks construction site, using a similar approach, Tan, (2005).

The incidents of rock falls of the entire cliff face are quite common, resulted in loss of life as well as damage to properties, in Ipoh region displays in figure 20.

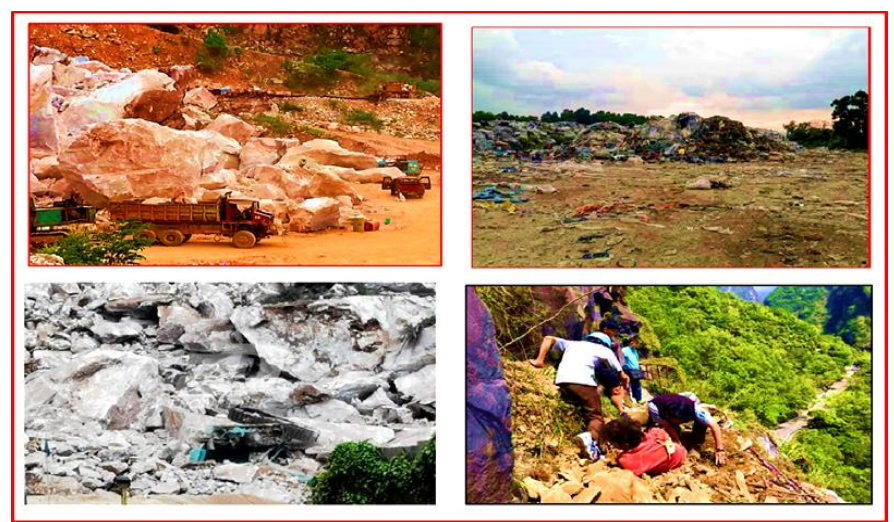

Figure 20: Displays the incidents of rock falls of the entire cliff face are quite common, resulted in loss of life as well as damage to properties, in Ipoh region

\section{IDENTIFYING KARST FEATURES BY EMPLOYING OF AERIAL PHOTOGRAPHS AND SATELLITE IMAGES TECHNIQUE}

Old aerial photographs are usually very helpful for the recognition of karst features such as sinkholes that now enclosed by buildings or human structures. Using low sunangle photographs with apparent shadows can emphasize subtle topographic features. Arial and satellite photographs used in this study to indicate the continuation of caves, sinkholes, drying streams, faults and in acting out the site evaluation.

Large-scale color stereoscopic aerial photographs are very helpful for identifying sinkholes. The key limitation of aerial photographs and satellite images is that, depending on the scale and explanation of the images, it may not be feasible to pin down small or shallow sinkholes.

The thorough elucidation of Arial photographs taken on different dates allows the chronology of freshly formed sinkholes to inhibit. The interpretations help to gain minimum estimates of the possibility of sinkhole occurrence and permit the study of the spatial-temporal allocated patterns of the subsidence phenomena. Using low sun-angle photographs with apparent shadows can emphasize subtle topographic features.

The further technique is the investigation of airborne and satellite multispectral and thermal images which may be used to distinguish the surface terrain patterns and acquire the 
variations in moisture, vegetation, colors, heat-related to subsidence areas and sinkholes. In this current work, usage of (2010) five layers satellite spot images of Perak state in scale $1 / 5000$, which presenting the location of construction sites covered by combined survey techniques in Kinta Valley, Perak, figure 21 .

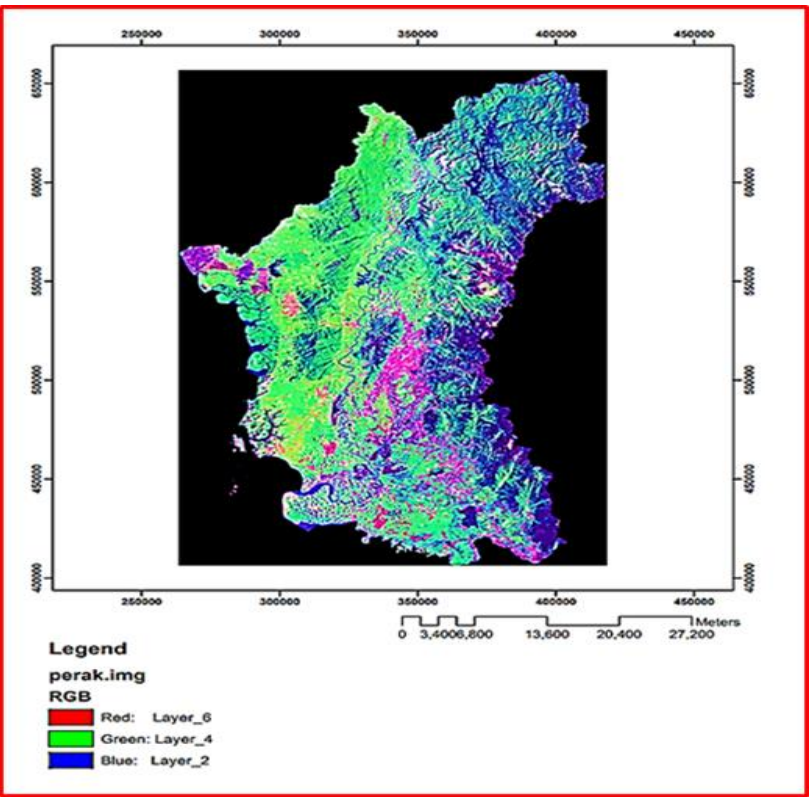

Figure 21: Spot images of Perak state on the scale 1/5000 of year (2010) presenting the location of study region (Kinta valley)

In addition, the Global Position System (GPS) and Geographic Information System (GIS) technologies have helped the examination considerably. The common methods of mapping land utilizing the changes are typically high in cost and low in precision. The remote sensing provides updated information on land by using these methods. Natural events and human meddling can observe as well by using current and archived distantly sensed data. The locations of construction sites in (Kinta valley) presenting in the Spot images of Perak state, figure 22.

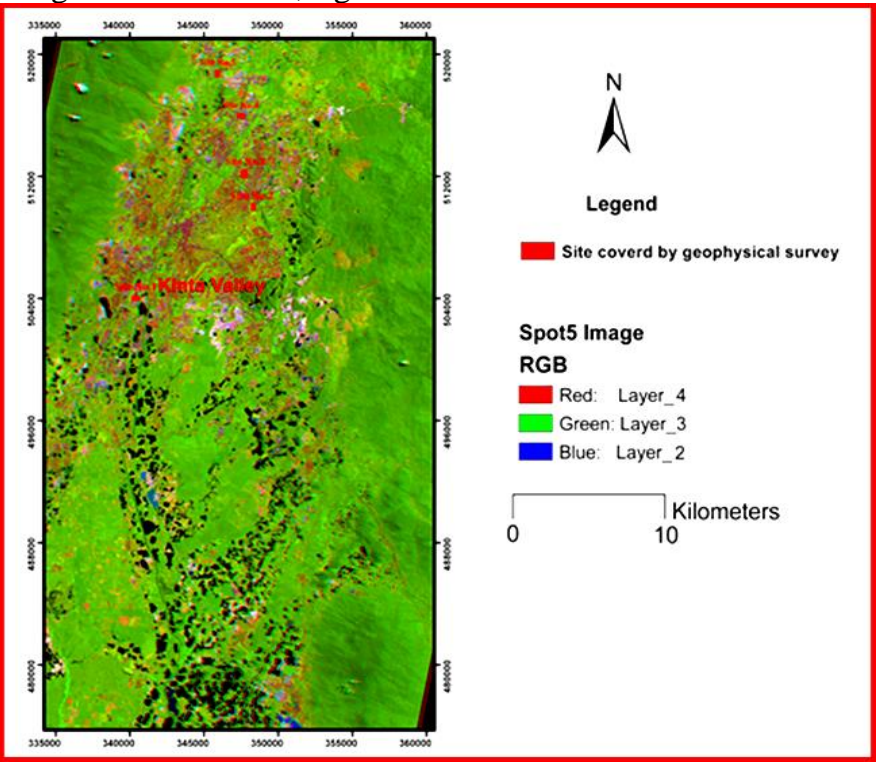

Figure 22: Five layers spot images of Perak state (2010) presenting the location of construction sites that covered by combined survey techniques in Kinta valley, Perak
From the interpretation of the aerial photographs of the studying region and its surrounding area, can identify the karst landscape such as limestone isolated residual hills and the cliffs, the consequence of the karst features and its possible origins in the relations to the geologic activities, the fractures systems, the topography, and the drainage patterns. Some old Arial photographs that have used in this study (operational in 1965- under the Colombo Plan have a scale of about $1: 25,000)$ present in figure 23.

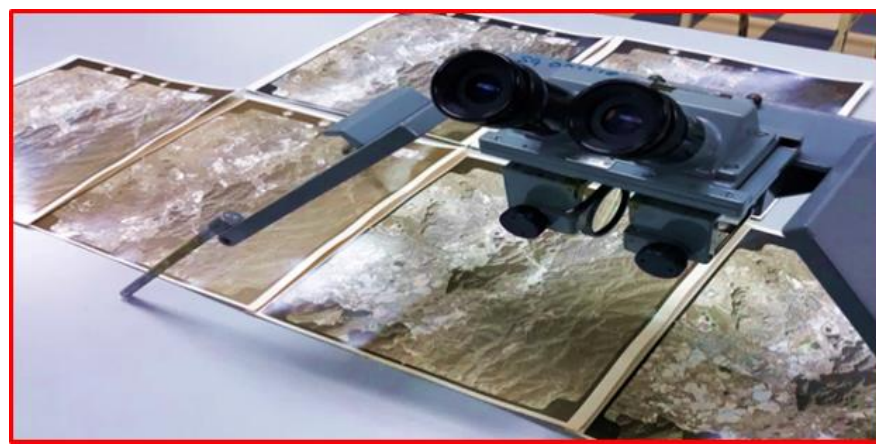

Figure 23: Display the old aerial photographs operational in 1965 under the Colombo Plan has a Scale of about 1: 25,000 used in this survey

From this technique, the interpretation of the karst features such as limestone isolated residual hills (mogotes) and the cliffs, the lineaments, forests, and the plantations. Moreover, detect the lineaments in all study regions, the expansion in the urban area, and the development activities in the mining area. The significance of the karst features and their possible origin in relation to the geologic events have concluded. The list of old aerial photographs that have used in this survey displayed in Table 1.

\begin{tabular}{|c|c|c|c|}
\hline Location & Roll no, & Line no. & Print no \\
\hline \multirow{11}{*}{ Ipoh-Perak } & $\mathrm{ClO}$ & L35N & $215-235$ \\
\hline & $\mathrm{Cl} 09$ & L34N & $162-150$ \\
\hline & $\mathrm{C} 24$ & L33S & $45-60$ \\
\hline & C-12-A & L32N & $35-20$ \\
\hline & $\mathrm{C}-6$ & L3IN & $60-40$ \\
\hline & C-5 & L30N & $30-20$ \\
\hline & $\mathrm{C}-5$ & L29S & $80-100$ \\
\hline & C-5 & L28N & $130-110$ \\
\hline & $\mathrm{C}-4$ & L27N & $170-190$ \\
\hline & $\mathrm{C}-4$ & L26N & $80-70$ \\
\hline & $\mathrm{C}-4$ & L25S & $40-55$ \\
\hline
\end{tabular}

Table1: The list of aerial photographs that employed in this study

In addition, the interpretation showed that the orientation of lineaments from Main Range and Kledang Range is far from irregular but shows the dominant strike of the northwest to Southeast with a subsidiary set, striking east- 
northeast to west-southwest. Conclusion made that these lineaments also observed clearly cutting the marbleized limestone of Kinta valley and the hills above it. The drainage in this study area is rather straight and angular and aerial photographs show that stream courses have controlled by the direction of lineaments (joints, fractures and fault systems) in the marbleized bedrock. In addition, the Arial photographs showed that the area of construction site \#1 shown that part of this site has covered with forest and the other part with plants. Furthermore the satellite images' shown that part of the forest in this site was removed for mining projects.

The Arial photographs showed that the area of construction site \#2 was a swampy area and covered with bushes. Furthermore, isolated residual limestone hills determine distributed in the south and southwest of construction site \#2. The aerial photographs give an idea that the area of construction site \#3 was covered with plants and containing several pits with different sizes. The aerial photographs are evidence that the area of construction site \#4 was a part of frost also small plants covered a few parts of the area. The aerial photographs showed that the area of construction site \#5 is a swampy area and covered with bushes.

Besides, the information from aerial photographs and satellite images together shown that Kinta valley resembling a huge basin with a triangular-shaped or V-shaped valley bounded by the Main Range on the east, and Kledang Range in the west. The northern tip of the triangle starts at around Chemore town in the north. The valley in this region extends to about $7 \mathrm{~km}$, and extends in the south around Kampar town to reach this region, at about $20 \mathrm{~km}$. This valley is extending over a distance of $45 \mathrm{~km}$ from extended from Sungai sepot in the north of Kinta valley to Tapah in the south. The first tower karst observed in Kinta Valley is Gunung Kanthan in the north, and the last is Gunung Tempurung in the south. The alluvial plain is situating over the valley area with active tin-mining pits separated over the study area. The major rivers originating from the granitic Main Range highland drains into most of the karstic land in the study area.

\section{Reconnaissance field surveys}

Through the direct grounds inspections in the five construction sites authorized to finding an indicator for the presence of sinkholes and other karst features could affect the construction projects. Many of soil covered collapse sinkholes were found distributed surrounding the study area and holes crammed with sand and other materials that are not particular on aerial photographs and satellite images due to many reasons. For example, the area may be enclosed by vegetation, sinkholes definite size or their depth is too small to be detected. The recorders including the diagram of the sinkhole are used for the description of each sinkhole, these recorders will supply information on the activity and the periods of the sinkholes and provide as indicators of the probable location of the future sinkholes in proximity to human structures and other observations. Several types of sinkholes observed in the construction sites under studies were viewing in Figure 24.

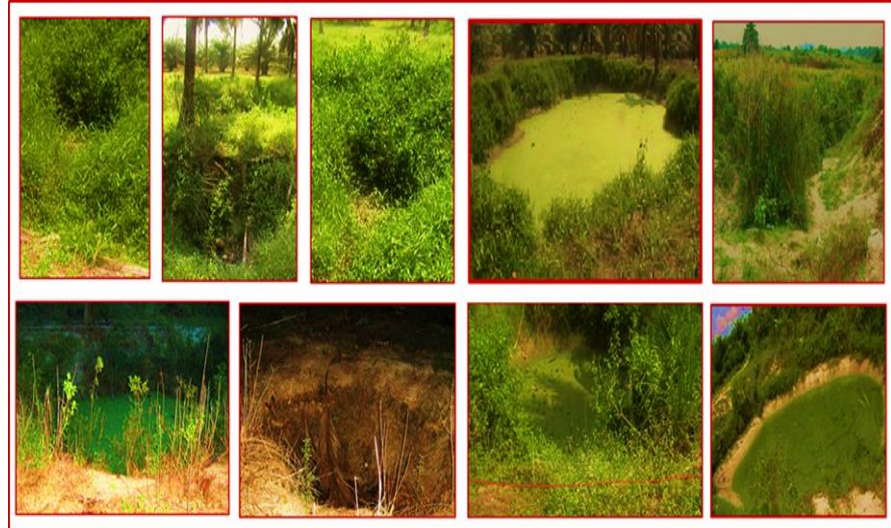

Figure 24: Land Photographs viewing several types of sinkholes observed in the construction sites under studies, such as soil covers collapse, subsidence, and pipes that identified as, water in-fill, empty, or covered with plants

The existence of features like muddy areas or the expansion of vegetation and holes crammed with materials may help detect shallow subsidence depressions. Generally, the application of geophysical surveys has desired to establish whether these irregular characteristics are interrelated to sinkholes or not.

Throughout the ground site inspection at construction site\#1, one depresses extended widely with $14.0 \mathrm{~m}$ in diameters in the ground surface was founded in the southeast of this site. Most of the trees of the forest over the ground in this site were found bending to the south direction. This gives a thought that this depression was formed due to subsidence that might happen in the near past in this site. Sinkholes, karstic cavities, a tubular channel of clay or air in-filled were present, the depth unknown that could threaten the integrity of this site.

Throughout the ground site inspection in construction site \#2, areas with organic gray clay shown over the ground surface along the site and covered with bushes. In addition, many soil cover collapse sinkholes were found surrounding the study area and small depress filled with rock fragment and sand, may its soil cover collapse sinkholes in the past then filled by human activity. Also in the satellite image of the area which shown as one large-size black spot extended widely with more than $200 \mathrm{~m}$. indicate that this area as before was swampy. This provides a consideration that sinkhole, karstic cavities, tubular voids clay or air in-filled were present in the subsurface that could threaten this construction site in the future.

Throughout the ground site inspection in construction site \#3, several soil pipes and pits were found and were marked as narrow to medium extends in diameters. Many small sinkholes were observed distributed in this site referred to soil covered collapse. Moreover, several small pits observed in the ground surface with depth between $1.0 \mathrm{~m}$ $2.0 \mathrm{~m}$. This gives the idea that the small cavities or sinkholes might be connected to one or more of a larger channel in diameter. Clay or air-filled karst cavities my present and that could threaten the integrity of this site.

Throughout the ground site inspection in construction site \#4, one depression was founded on the surface of the 
study area and immediately to the west of this site and determine as a narrow to medium exposed sinkhole extended with $\sim 15.0 \mathrm{~m}$ in diameters. This gives a consideration that might be channel connected to one or more of a larger channel in undetermined depth. Karstic cavities may be present contain clay or air in-filled that could threaten the integrity of this site.

Throughout the ground site inspection in construction site\#5, no sinkhole was found. More than four big black spots imply it to be old swamps with gray clay were recognized which might contain sinkholes in the subsurface. On the other hand, the aerial photographs of the area viewing the positions of four big black spots, three of them circular to semi-circular in shapes and the others are with longitudinal shape. However, due to human activity and excavating work as exmining areas, most of these features were packed with sand and other material and among them; three areas with deposits of grey swamp clay in circular shape were acknowledged. The clay seems to sink down due to numerous causes.

\section{FACTORS AFFECTED THE SINKHOLES TO COLLAPSE AND EVOLUTIONS IN KINTA VALLEY REGION, PERAK STATE}

The collapses sinkholes are occurring mainly in the region of covered limestones bedrocks in Kinta Valley, Perak state. While the regions of covered marbleized limestone bedrocks with less degree of collapse sinkholes to occurring. The study region tends to have fewer noticeable surface water sources of ponds and streams and can easily drain downward through joints and fractures in the marbleized limestone bedrock.

There are several causes for the occurrence of sinkhole collapse in the Kinta Valley, Yassin R.R, (2012:2013). The primary reason among them is the irregular distribution of unconsolidated material on the bedrocks surface. The secondary reason is the running of heavy rainwater on the ground surface. The third reason is the heavy acidic rainfall in this region. The fourth reason is the earthquakes and the subsidence movement. The fifth reason is the heavy loads of buildings or foundations. The sixth reason is the human influence. The seventh reason is the vibration from traffic. The eight reasons are the weather patterns. The ninth reason is the groundwater movement. The tenth reason is the water quality. The eleventh reason is Air high pollution. All these reasons after the development of the sinkholes and other karst feature rapidly in this tropical area of Peninsular Malaysia. However, it still requires more studies to provide sufficient results to conclude the relationship between sinkholes and subsidence, in the following the presentation of the factors that causes for the occurrence of sinkhole collapse:

\subsection{The Irregular distribution of unconsolidated material on the bedrock surface}

The primary reason among them is the result of the irregular distribution of unconsolidated material on the bedrock surface of clayey soil, sandy clay or sand, due to mining and human activities, which is one of the major obstacles to the development of sinkholes in these karst regions. The mining activities often cause an increase of deformation into the soil and bedrock. Occasionally, mining activities disturb or overload the roof of the voids and leading to a sudden collapses of their roofs. Construction or mining activities that interrupt the drainage from a large area and concentrate the information of this drainage at the one spot may also trigger a sinkhole formation.

\subsection{The Running of Heavy Rain Water on the Ground Surface}

The secondary reason for the source of sinkholes or subsidence in the study region is the running of heavy rains water on the ground surface, which channeled towards the subsurface. Then the dissolution processes of marbleized limestone bedrock in the Kinta Valley region by rainwater which absorbs the carbonic acid solution by percolating through the natural features, which is known technically as joints, fractures or faults within the bedrock, and was slowly, dissolving it. Through geologic time, dissolution along these zones of weaknesses has resulted in the formation of the cavities within the bedrock, and the soil immediately above these cavities would migrate or collapse down.

The heavy rains, the rapid infiltration resulting from heavy rainstorms can often generate sinkholes, remove the soil and the sand particles from the surface, and drain it to the groundwater. In some cases, the extra water weight from infiltrated rain may even be enough to trigger a collapse. in a period of lack, drying can reduce soil strength and tends to cause shrinking then cracking and lead to dripping of soil from the roof of the cavity, and finally, a collapse resulting. Some soil moisture is good because it increases the strength and reduces erodibility of the soil, but too much or too little moisture generally reduces the strength of the soil resulting in the collapse.

The interaction among the factors is complex, but the result is that some moisture improves the soil strength; too much or too little weaken it. A soil cavity exists a few meters below the surface. Following a period of much rain, soil moisture content may become high enough to reduce the strength of the soil then a collapse will occur.

\subsection{The heavy acidic rainfall in this region}

The third reason that some of these old karst features such as sinkholes, and caves could create due to the heavy and acidic rainfall in this region through the past period. It is representing one of the main characteristics in the development of the karst process in the study area. Especially it contains solutions and sediments such as clay, sand and mineralized materials.

The collapse sinkholes occurring mainly in the region of cover limestones in Kinta Valley, Perak state. While the regions of marbleized limestone bedrocks with less degree of collapse sinkholes to occurring. Collapse sinkholes seem to be most widespread in Valley. Cavities of various sizes tend to develop in the overburden soil where infiltrating surface waters erode the soil by piping and transport it downward through joints or cracks in the bedrock. 
Then these features widened and enlarged by the dissolving of the rock due to the infiltrating water. This produces a drainage system and the eroded soil from overburden that is carrying through. Over a long period, the infiltrating of $\mathrm{CO}_{2}$-charged water dissolves more and more carbonate rock and enlarging the cracks to $1.0 \mathrm{~m}$ or more in width. These solution-enlarged joints are most effective in transporting soil when they are above the water table.

\subsection{The effects of Earthquakes and Subsidence movements}

The fourth reason is the effects of Earthquakes and Subsidence movements. Fatiha R, AL-Kouri O, Yassin R., (2010) carried out site investigations in kampong Jeram, northwest of Kampar city, Kinta Valley, which showed that there are different levels of damages in the mining area. In addition, the image processing and statistical analysis have shown that the number of sinkholes had increased after the tsunami that took place on 26 December 2004, with up to more than $10 \mathrm{~m}$ in diameter.

A recent spate of sinkholes, totaling about 40 in number, appeared in an area south of Ipoh city within the Kinta Valley soon after the major earthquake of Sumatra on 26 December 2004.

According to (Chow WS, 2005), these sinkholes have correlated with the tremors from the Sumatran earthquake. However, the geologic conditions where these sinkholes were developed, namely limestone bedrock overlay by mostly sandy mine tailings, were said to have a high potential for the formation of sinkholes and the earthquake vibration supplied the triggering factor to initiate their development. It has reported that the same earthquake also triggered a spate of sinkholes in Thailand (Chow W. S, 2005).

The geophysical survey in the area according to (Yassin R. R, 2012) showed many subsurface cavities and sinkholes which were not connected to the surface. This made the area dangerous to be used for construction accommodation for animals or for living in by farmers due to any collapse in the near future.

\subsection{The Heavy Loads of the Buildings or the Foundations under Constructing}

The fifth reason is the heavy loads of buildings or the foundations under constructing causing the failure in the ground surface. In the karst region if the cover layer is mainly granular, sandy full of porous, in construction sites the foundation will settle quickly and the water is squeezed out relatively quickly. If the cover layer is comprised of clay with less porous, the water is squeezed from beneath the foundation very slowly.

The increase of permanent load on any foundation will cause it to settle further over time. When the overloaded foundation settles, cracks will appear more than the other foundations surrounding it. After time, expensive repairing will need to the cracking and damages when the foundation settles slowly. When settlement will occur there is nothing stopping to it.
The Failures some time happen due to constructing of new panel walls in various locations because the engineering designer does not account for the unexpected additional loads that probability used above the maximum capacity.

In Malaysia, one of the mutual problems is going through the design of the spaces within the building. When changing the design layout of any foundation rooms and spaces it would be useful to maintain the overall weight acting in the same zone of the area. The removes of the existing panel walls and constructing of new panel walls in various locations by using bricks, the new effectively will change the weights that each set of the foundations designed to carry. This also assumes that the building structural beams and slabs can carry the weight of the walls at the new locations.

In addition, the heavy loads of construction projects on the surface of the land, such as large building structures may lead to unexpected sinkholes. Disturbances in the surface soil, such as digging; drilling and injections of water in the ground may cause sinkholes to form, (Kochanov and William, 1999); (Newton, J. G, 1987).

\subsection{The Human Influence}

The sixth reason is the human influence, sinkholes are of two types, natural sinkhole and induced sinkhole that have accelerated or caused by humans. Most of the induced or accelerated sinkholes caused by humans in the construction site are due to the alteration of surface drainage over unconsolidated deposits resting on the openings at the top of bedrocks. The collapse mechanisms include loading, saturation, and piping. The decline in the water level is due to ground-water withdrawals causing a loss of buoyant support, an increase in velocity of water movement, water-level fluctuations, and an induced recharge.

These types of sinkholes usually happen in places that were otherwise unlikely to happen. The sudden development of both types of sinkholes results from the collapse of the roof of a cavity or cavern in rock or from the downward migration of unconsolidated deposits into solutional enlarged openings in the top of bedrock (Newton, J. G, 1987).

Soil conventionally is a material used in burial sites, building foundations and as construction material for buildings. The use of soil removal may also cause unexpected surface-level changes that lead to sinkhole developments.

The human activities often cause increased deformation into the soil and bedrock. Occasionally, construction activities disturb or overload the roof of a void leading to a sudden collapse of the roof. Construction or mining activities that intercept the drainage from a large area and concentrate the information of this drainage at the one spot may also trigger a sinkhole formation.

An study of collapse sinkholes that occurring over a nearly fifty-year by (Williams and Vineyard, 1976) shows that, about half of collapse sinkholes were causes a natural process that can extend many thousands of years, and about half were caused due to human activities, due to the altering of drainage conditions. 


\subsection{The Vibration from Traffic}

The seventh reason is the vibration from traffic, due to heavy vehicle passage along the roads and highways in Perak can cause the ground to vibrate. These vibrations will be more effective if the road is very busy. The consequence of this is that the ground surface will lose its strength in response to strong ground shaking. Therefore, at least 26 subsidence and sinkholes have been found in the areas close or near to the express high way of Gopeng to Ipoh and from Ipoh to Kuala Kangsar. These sinkholes were most probably developing due to the frequent traffic crowds (Kochanov and William, 1999).

\subsection{The Weather Patterns}

The eighth reason is the weather patterns, the seasonal changes, such as the changes that occur from cold and hot weather, may cause sinkholes due to the fluctuations in the groundwater-level. Extreme precipitation is another cause of sinkholes due to the unexpected increase in water, such as flooding, or decrease in water, such as a drought, ( Sinclair, W. C.,1982); Newton, J. G.,1987).

In addition, due to unusually wet or dry weather can generate a natural collapse process and established the stage for transport of soil from a growing void.

\subsection{The Groundwater Movement}

The ninth reason is the groundwater movement, lowering of the water table will tend to increase that effectiveness. After a period, this process can produce a large cavity in the overburden soil layer after collapse occurring Newton, (1987). The advanced development of a cavity due to the collapse of overburden layers will creation of a collapse sinkhole.

If the groundwater table is high, the hydrostatic pressure on the roof of the void prevents the collapse of the soil into the cavities. However, if the groundwater table there is lowering down, a rapid collapse to the soil will happen here leading to the formation of a sinkhole. Studies have shown that rapid fluctuation changes in the elevation of the water table can lead to the formation of sinkholes.

The moisture conditions in the overburden soil are most important because that moisture will affects the soil strength. Many factors can affect soil moisture; $1 \mathrm{st}$, is the soil texture, 2nd, is the soil mineralogy, 3rd is the climate, 4th the evaporation, 5th the transpiration of moisture that uptake by vegetation, and 6th the depth to the water table.

The soil moisture and water table fluctuated naturally during the seasons in response to patterns of rainfall, evaporation, and transpiration. Groundwater is not static, or stationary; it moves through pores and cracks in the bedrock along a slope, from higher elevations to lower, eventually discharging into streams.

For a specific reason, the collapse sinkholes caused due to over-pumping for dewatering. In addition, pumping a well forms a cone-shaped depression in the water table around the well and becomes large enough due to continued pumping. An increase in soil piping and ground subsidence will reduction the support beneath the foundations of buildings.

The extended period of water lack and water withdrawal for use and excess water withdrawal from the area will lower the water pressure in the limestone bedrock that, in turn, will increase the water seepage from the overlying soil into the limestone bedrock. This increased in the seepage will wash the soil down into the cavities and led the surface to collapse.

\subsection{The Water Quality}

The tenth reasons is the water quality, Water samples were taken from (40) forty numbers of sinkholes and surface water pools have collected and analyzed. The results of these analyses showed that an extensive change in the chemistry of these waters have occurred under natural conditions. The dissolution processes of the dissolved material are exceedingly high. The results for the Total Dissolved Solid (TDS) and $\mathrm{pH}$ of the water samples are as follows:

$\mathrm{PH}$ is the reading that is a measure of the acidity or basicity of water. The $\mathrm{pH}$ value reading in the study area ranges between $6.25,6.49,6.65$ and 6.77 . Pure water with a $\mathrm{pH}$ close to 7.0 at $25 \mathrm{Co}$ is Neutral. Water with a pH of less than 7 is acidic and with a $\mathrm{pH}$ greater than 7 is basic or alkaline.

Total Dissolved Solids (TDS) reading ranges from (85.4, 125.7, 185.8 to $249 \mathrm{mg} / \mathrm{L}$ ). The low total dissolved solid value will cause the resistivity value to be high. This is due to the lack of ions in some materials as an electric conductor. The results of these analyses showed the sodium content varying from 2.64 to $2.65 \mathrm{mg} / \mathrm{L}$. and chloride content varying from 2.70 to $17 \mathrm{mg} / \mathrm{L}$. The analysis shows that extremely high calcium content ranging between 48.2, 65.4 and $73.8 \mathrm{mg} / \mathrm{L}$.

\subsubsection{The Air highly pollution}

The eleventh reason is the Air highly pollution, which is the phenomenon that contaminates the environments by particles in solids, in liquids, and in gases. In Malaysia and other countries in Southeast Asia, air pollutions increased and led to an increase in the amounts of liquefied carbon dioxide and other pollutants. The air pollution index (API) levels recorded the reading that ranging between (112 to 300) in the sky of various states in Malaysia peninsular.

Air pollution is a complex collection of serious problems that can occur either within a relatively small area or over a wide region. It contaminates the air, due to the activities of burning large jungles area and clearing it, for construction or mining projects. Furthermore, the practice by the farmer on the burning of large-scale tropical peatlands and forest areas to plants palm oil trees in Indonesia and Malaysia. This burning of tropical peatlands is so significant for greenhouse gas emissions because these areas store some of the highest quantities of carbon on Earth, accumulated over thousands of years. 
These activities resulted in the emission of large volumes of (smoke and haze pollutants) into the atmosphere. These events have a large impact on the development and quick increase of liquefied carbon dioxide and effective of the dissolving process of carbonate rocks. The impact of peat fires on global warming may be more than 200 times greater than any fires on other lands. Burning and draining these lands for agricultural expansion or conversion to oil palm or pulpwood plantations leads to a huge confound in greenhouse gas emissions.

Fires also emitted methane $\left(\mathrm{CH}_{4}\right)$ is a greenhouse gas (21) times is more powerful than carbon dioxide $\left(\mathrm{CO}_{2}\right)$. The (Peat fires) could emit 10 times more than the $\left(\mathrm{CH}_{4}\right)$ emitted from fires occurred on different types of land. Emissions of $\mathrm{CO}_{2}$ leading mostly to climate change continue risks to the health in both of the land and Ocean. In the ocean, $\mathrm{CO} 2$ will become an alarm that is more conspicuous.

Acid rainfall is one of the environmental problems in the world and in the pacific region and Southeast Asia country. These areas with the highest acid rainfall, some of these countries have the most sensitive natural resources. Rainfall is the most acidic due to several factors such as human-caused (Anthropogenic) or natural (Nonanthropogenic).

Acid rain is the term widely recognized, for the precipitation that more acidic falls in the ground surface from the atmosphere. It is the result of multiple, complex chemical reactions in the atmosphere between emissions of polluting species or types such as sulfur dioxide $\left(\mathrm{SO}_{2}\right)$ producing from fossil fuels, fired power stations and smelters. Furthermore, Nitrous oxide $\left(\mathrm{N}_{2} \mathrm{O}\right)$ producing from all types of motor vehicle exhausts with water and oxygen to produce corrosive substances.

Sulfur dioxide $\left(\mathrm{SO}_{2}\right)$ can react quickly with hydroxyl radicals in the atmosphere to produce $\left(\mathrm{SO}_{3}\right)$ which reacts with water to become sulfuric acid or moved hundreds of kilometers with the wind before reaction. Sometimes, it is absorbing in clouds to become sulphuric acid via various chemical pathways to the liquid phase. These chemicals will converted to sulphuric acid and nitric acid in the atmosphere, and can be carried by the winds for many miles from where the original emissions took place, then fall via precipitation, or alteration into the gas phase via evaporation.

Continuous exposure to $\left(\mathrm{SO}_{2}\right)$ acidic rain causes serious damage to materials such as marble rocks, limestone rocks. An eroded in the surface of limestone $\left(\mathrm{CaCO}_{3}\right)$ that will be replaced by sulfates $\left(\mathrm{CaSO}_{4}\right)$ is water-soluble and may be washed away easily by rain will result in an cavity in these carbonates rocks. If any eroded happen due to the rain in the surface will result in subsidence sinkhole over the cavity.

\section{SITES INVESTIGATION OF VARIOUS CLASSES OF SUBSURFACE KARST FEATURES BY APPLYING OF ELECTRICAL RESISTIVITY TOMOGRAPHY (ERT) TECHNIQUE}

Electrical Resistivity Tomography survey is an extensively used method in geophysical surveys for investigation of various subsurface geomorphological features and structures. In this study, a Two-dimensional electrical resistivity tomography (ERT) survey has performed across five construction sites in Perak, Malaysia. The survey has carried out to imaging the subsurface to locate evidence for near-surface karstic features such as voids, cavities, channel pipes and sinkholes as a primary objective. To discover the reliability of the electrical resistivity method if can identify such karst features or not as a secondary objective. Evaluate the subsurface karst ground conditions that based on features that occur in the intact carbonate rocks and its level and describe if that can result in potentially dangerous collapse or ground failures at construction sites that superimpose these features as the final objective.

Resistivity traverses have conducted along the studied sites. The orientation, extension and the degree of inclination of those profiles have shown in the location map. The correct resistivity data was interpreted using res2din Version 3.54 software. Interpretation of geophysical data indicated that the area has exaggerated by a sinkhole that thus contains clay and water, making the area less resistive to electrical current. Early plans are needed to mitigate the risk of structures in these construction sites over karstified carbonate bedrock.

Geophysical ERT technique can be used to detect the changes in the physical properties and the anomalies of the ground connected with air-filled, water-filled or sedimentfilled cavities, channel pipes, subsidence hang down zone, irregularity of bedrock topography and covered sinkholes. The best option is to apply two or more geophysical techniques and then evaluate the results with each other. It is wise to apply the geophysical techniques on the sites prior to drilling as one of the phased sequences of investigation. The area with abnormality and the normal areas are recognized then delineated and the normal areas can be planned for construction projects.

Evaluation of the geophysical techniques used in karst areas have presented by Hoover (2003) and Waltham et al. (2005). Numbers of previous geophysical studies in karst terrain have mentioned such as in applying (ERT) technique to map the bedrock surface, Zhou, W., et al. (2000), in a site located southern Indiana where the limestone is cover by about $9 \mathrm{~m}$ of clayey soils. Forty-nine profiles have conducted over an area of approximately $42,037 \mathrm{~m}^{2}$. The repeatability of the ERT technique has evaluated by comparing the previous drilling section with interpreted ERT section from pairs of transects where they crossed each other.

To identify the depth of mud-filled void and its extension by William E. D., et al. (2002), through applied geophysical surveys at a site on the Oak Ridge Reservation (ORR), Tennessee in the USA. The data suggest that an optimal scheme for detailed karst mapping might consist of multi-electrode resistivity surveying followed by joint inversion of gravity and seismic Travel time data. The resistivity results could use to produce an initial model for the seismic and gravity inversions. To identify buried sinkholes and other karst features in the zone of karst terrain Kachentra N., Tanad, S. (2007) applying of 2D and 3D resistivity imaging resistivity (ERT) survey at Ban Pakjam in Huaiyod 
district, Trung province, in the southern part of Thailand. The $2 \mathrm{D}$ resistivity surveys clearly show the central depression as well as resistivity contrasts between the cover sediments, delineating the in-filled sinkholes, underlying weathered bedrock and mapped the locations of sinkholes in this covered karst terrain.

\section{1 geotechnical field survey \\ 10.1.1 introduction}

In this study, an effective geotechnical and environmental engineering tool has been used named as (ERT) technique. In particular, the ERT technique is widely used for imaging the subsurface for environmental and engineering studies and for subsurface mineral investigations. Also used in mapping the subsurface karst hazards regions and imaging of the groundwater aquifers.

Moreover, (ERT) technique used in determining the depth of bedrock, location of contaminated plumes and acquiring information on the elevation of the groundwater table, etc. This technique is especially preferred for site characterization in karst terrains (W. Zhou, 1999). When Electrical Resistivity Tomography data have used in combination with exploratory borehole, the cost and the time necessary for the project can significantly reduce. When the geophysical data are constrained by borehole control, they can provide accurate and high-resolution interpretations.

In addition, the use of this geotechnical field survey can be of great help in terms of setting additional borehole control. Electrical Resistivity Tomography techniques have successfully used in the evaluation of Karst activity at highway construction sites; identify buried karst features affecting the road Projects, for defining the depth to bedrock in covered Karst terrains. In evaluations the geotechnical site investigation technique such as trenching and borehole drilling, using electrical resistivity tomography, found that ERT is more rapid, relatively more inexpensive, and less labor-intensive. In karst terrains, where are lateral variations in the depth of bedrocks was vary greatly. Analysis of the subsurface conditions between two boreholes can often provide mistaken results. Using of ERT technique could provide more accurates information about the subsurface ground conditions to the area between many boreholes.

The main benefit of the (ERT) technique is that the data can be obtained without interruption of integrity in the investigated objects. In addition, there are several disadvantages to the utilization of (ERT). The methodology of (ERT) requires planting or fixing of electrodes into the ground, if in cases where the study area has covered by the inflexible or hard and massive rock it is really challenging to take resistivity measurements. Another disadvantage is that the vertical resolution of the processed electrical resistivity data decreases with depth.

Figure 25 shows, the typical setup for a 2-D survey with a number of electrodes along a straight line attached to a multi-core cable carried out in 2012. Normally, a constant spacing between adjacent electrodes is used. The multi-core cable is attaching to an electronic switching unit that is connecting to a laptop computer.
The sequence of measurements to take, the type of array to use and other survey parameters (such as the current to use) normally entered into a text file, which can be read by a computer program in a laptop computer. Different resistivity meters use different formats for the control file; they need to refer to the manual for the system. After reading the control file, the computer program then automatically selects the appropriate electrodes for each measurement. In a typical survey, most of the fieldwork is in laying out the cable and electrodes.

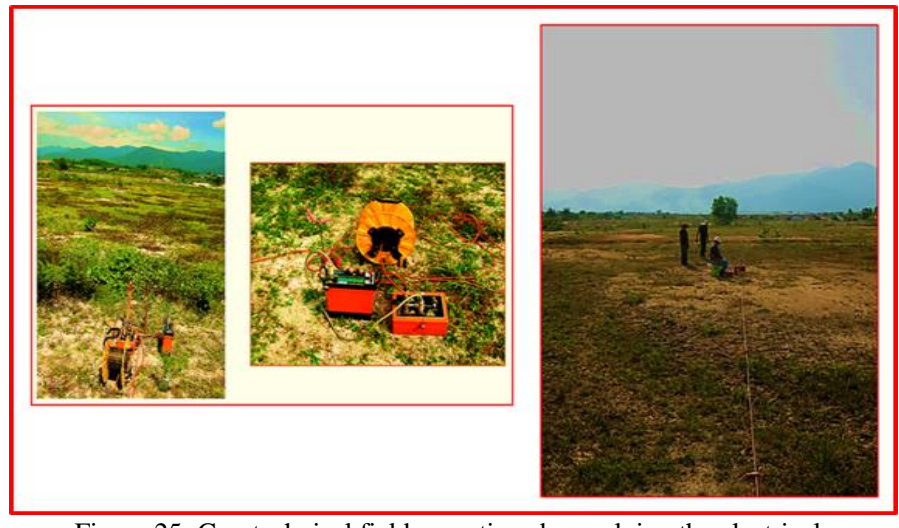

Figure 25: Geo-technical field operations by applying the electrical Resistivity imaging/tomography (ERT), in the north of Ipoh city Perak, Malaysia. The instrument type SAS1000 used in this survey and the typical setup for 2-D electrical imaging/tomography surveys, with a number of electrodes along a straight-line attached to a multi-core cable

After that, the measurements have taken automatically and stored in the computer. Most of the survey time has consumed in waiting for the resistivity meter to complete the set of measurements. To obtain a good 2-D picture of the subsurface, the coverage of the measurements must be 2-D as well.

Note that as the electrode spacing increases, the number of measurements decreases.

The number of measurements that can obtain for each electrodes spacing, for a given number of electrodes along the survey line, depends on the type of array used. The Wenner array gives the smallest number of possible measurements compared to the other common arrays used in 2-D surveys.

\subsubsection{Instrumentation and Measurement Procedure}

1. The geo- technical field survey has carried out using SAS1000 resistivity meter that has an inherent microprocessor to select the appropriate four electrodes for each measurement automatically.

2. Two dimensional (2D) - electrical resistivity imaging/tomography survey (ERT) are carried out employing a large number of electrodes, 41 or 81 along a straight line, coupled to a multi-core cable.

3. In common at a constant spacing of $5.0 \mathrm{~m}$ or 10.0 $\mathrm{m}$ between two electrodes and on average spaced at $15.0 \mathrm{~m}, 20.0 \mathrm{~m}, 25.0 \mathrm{~m}, 30.0 \mathrm{~m}$, the intervals between each profile 
4. Wenner configuration were displayed at the this survey in construction sites.

5. The length of each profile is $200 \mathrm{~m}$ or $400 \mathrm{~m}$ depending to the size of the area.

6. A laptop computer was engaged to set the data is already inputted into

7. RES2DINVver.3.54. inversion software to develop the resistivity model.

The survey has carried out using a SAS1000 system, manufactured by ABEM Inc. of Sweden. Generally, this resistivity tool provides a greater combination of spatial resolution and depth of the investigation on the karst terrain than any other geophysical technique. The resolution provided by the resistivity technique is a function of the electrode spacing and other factors, including subsurface heterogeneity and conductivity contrasts. The depth of investigation is a function of the length of the employed twodimensional arrays.

\subsubsection{Electrical Resistivity Tomography (ERT)}

Two-Dimensional (2-D) electrical resistivity imaging/ tomography surveys were carried out, and employed a large number of electrodes using 41 channels 61 channels and channels 81 in the type of array name of Wenner configurations, have displayed at all selected construction sites. These electrodes have connected to a multi-core cable (Griffiths DH \& Barker R D, 1993), configured in a Wenner array figure 5-5. The multi-core cable attached to an electronic switching unit, and it used automatically selects the applicable four electrodes for each measurement.

The field systems have a built-in microprocessor system, which codes the sequence of measurements to take the type of array to use, while other survey parameters such as the (Current) to use is normally entered into a (text file). This read by the computer programs in the field system's computer. Different resistivity meters use different formats for the control file, which means that it will need to refer to the system's manual. After reading the control file, the computer program automatically selects the appropriate electrodes for each measurement, which is the very advantage of this system, especially in the context of a rugged or uneven terrain.

In a typical survey, (most of the fieldwork time involves laying out the cable and electrodes). After that, the measurements have (Automatically) taken and then store in the computer device. To obtain a good 2-D picture of the subsurface, the coverage of the measurements must all correct. In order to get the best results, the measurements in a field survey should be carried out in a systematic manner so that all the possible measurements have made as far as possible. This will affect the quality of the interpretation model obtained from the inversion of the apparent resistivity measurements (Dahlin T. \&Loke MH, 1998).

As the electrode spacing increases, the number of measurements decreases. The number of measurements that can be obtained for each electrodes spacing for a given number of electrodes along the survey line depends on the type of array used. The Wenner array provides the smallest number of possible measurements, compared to the other common arrays that have used in 2-D surveys.

\subsection{Data collection}

When the succeed measurements were done. The Electrical resistivities data were acquired from the twodimensional (2-D) electrical resistivity traverses which functional via 41-channel and 81 arrays in Wenner configuration in order to image the subsurface in sites with and without evidence of subsurface karst features, and in proximity and adjoining to active and non-active sinkholes.

For the traverse with lengthwise of $200 \mathrm{~m}$ and electrode spacing of $5 \mathrm{~m}$, the total 190 data points have composed for each (41-electrodes) in one traverse. For the measurement lengthwise of each traverse with $400 \mathrm{~m}$ with electrodes spacing of $5 \mathrm{~m}$, the total 340 data points have composed for each (81-electrodes) in one traverse.

\subsubsection{Data Collection in Construction Site\#1(Taman Batu Gagah Perdana)}

Four " 4 " of 2D electrical resistivity traverses, traverse no. 1 to traverse no. 4 have controlled over and along the survey area in construction site \#1. This located in the Taman Batu Gagah Perdana area to the southwest of Ipoh city. The orientation of these traverses in the direction of (NW80 ${ }^{\circ} \mathrm{SE}$ ), and the level of those lines are viewing in the Google earth satellite images in figure26. Two dimensional (2-D) Electrical resistivity tomography (ERT) was carried out in this site by using 41-channel array in winner configuration. The length of each traverse was $200 \mathrm{~m}$, with an electrode spacing of $5.0 \mathrm{~m}$, and a space interval of about $25.0 \mathrm{~m}$ between each traverse. The total length of all traverses in this site was $800 \mathrm{~m}$, covering an area of $25000 \mathrm{~m} 2$. About 190 data points were composed for each (41-electrode) in one traverse, and on average, and about 760 data were collected for a total of four traverses in this site.

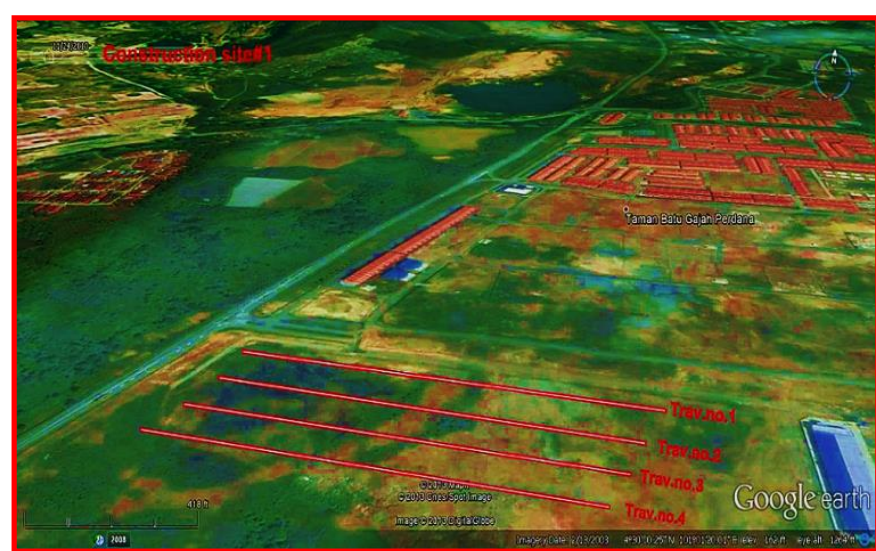

Fiqure26: Google earth satellite image viewing the location of resistivity traverses in construction site \#1 (Taman Batu Gagah Perdana)

\subsubsection{Data Collection in Construction Site \#2 (Gunning Rapat)}

Four "4" of 2D electrical resistivity traverses, traverse no. 1 to traverse no. 4 were controlled over and along the survey area in construction site \#2 which located in gunning Rapat area to the southeast of Ipoh city. The orientation of these traverses in the direction of (NW10 $\mathrm{SE})$ 
and the level of those lines are viewing in the Google earth satellite images in figure 27. Two dimensional (2-D) Electrical resistivity tomography (ERT) was carried out in this site by using 41-channel array in winner configuration.

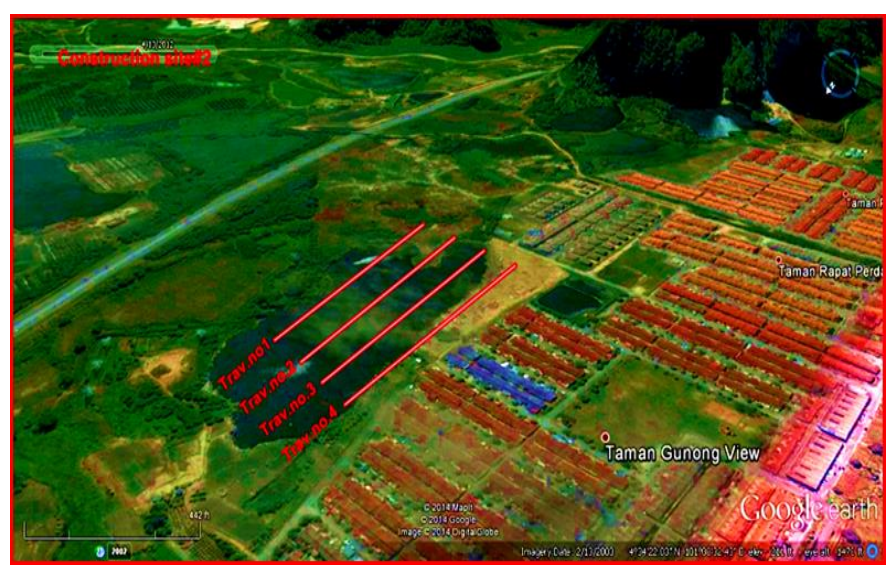

Fiqure27: Google earth satellite images viewing the location of resistivity traverses in construction site \#2 (gunning Rapat)

The length of each traverse was $200 \mathrm{~m}$, with an electrode spacing of $5.0 \mathrm{~m}$, and a space interval of about $25.0 \mathrm{~m}$ between each traverse. The total length of all traverses in this site was $800 \mathrm{~m}$, covering an area of $20000 \mathrm{~m} 2$. About 190 data points were composed for each (41-electrode) in one traverse, and on average, and about 760 data were collected for a total of four traverses in this site. On average, 190 data points were collected for each (41-electrode) in one Traverse and about 760 data points on average were collected for a total of four traverses in this site.

\subsubsection{Data Collection in Construction Site \#3 (Ipoh City)}

Three "3" of 2D electrical resistivity traverses, traverse no. 1 to traverse no. 3 were controlled over and along the survey area, construction site \#3 which located in Ipoh city near Tesco extra (Kinta Valley) area. The direction of these traverses in $\left(\mathrm{N} 20^{\circ} \mathrm{W}\right)$, and the level of those traverses are viewing in the Google earth satellite image in figure 28. Electrical resistivity tomography (ERT) was carried out by using an 81-channel array in the Wenner configuration that was used in this site.

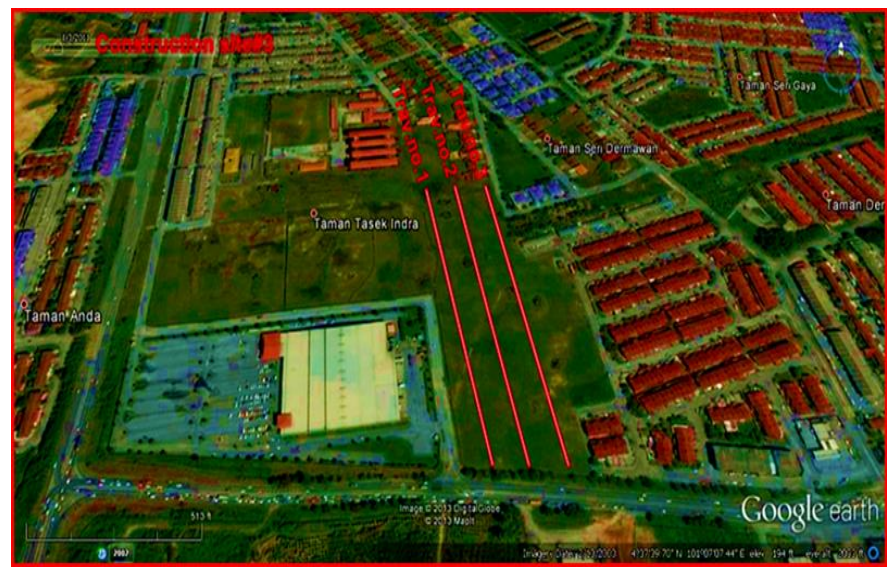

Fiqure28: Google earth satellite image viewing the resistivity traverses in construction site \#3 (Taman task Indra)
The length of each traverse was $400 \mathrm{~m}$. The spacing interval about $25.0 \mathrm{~m}$ between each traverse and the electrode spacing of $5 \mathrm{~m}$. The total length of all traverses in this site was 1200 $\mathrm{m}$. covering an area of $300000 \mathrm{~m} 2$. The two Dimensional electrical resistivity data were acquired and on average, 340 data points were collected for each (81-electrode) in one traverse, and on average, about 1020 data have collected for total three traverses in this site.

\subsubsection{Data Collection in Site \#4 (Taman Tasek Jaya)}

Four "4" electrical resistivity traverses, traverse no. 1 to traverse no. 4 were controlled over and along the survey area, in construction \#4 which located in Taman Tasek Jaya to the north of Ipoh city in (Kinta Valley) area. The direction of these traverses in were oriented in (NE52oSW), and the level of those traverses are viewing in the Google earth satellite image in figure 29.

Two dimensional (2-D) Electrical resistivity tomography (ERT) was carried out in this site by using 41 channel array in winner configuration. The length of each traverse was $200 \mathrm{~m}$. The spacing interval about $25.0 \mathrm{~m}$ between each traverse and the electrode spacing of $5 \mathrm{~m}$. The total length of all traverses in this site was $800 \mathrm{~m}$. covering an area of $200000 \mathrm{~m}^{2}$. The two Dimensional electrical resistivity data were acquired and on average, 190 data points were collected for each (41-electrode) in one traverse, and on average, about 760 data have collected for the total of four traverses in this site.

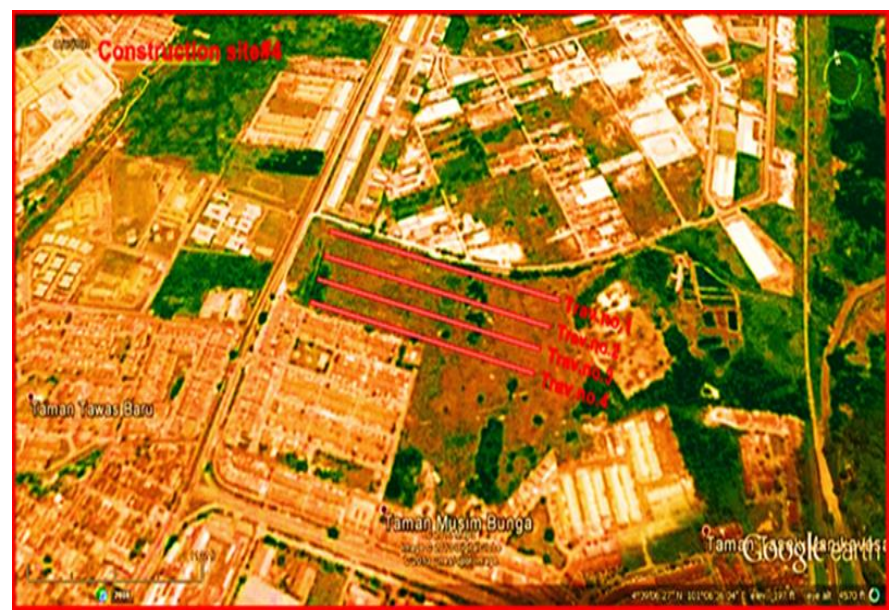

Fiqure29: Google earth satellite image viewing the location of resistivity traverses in construction site \#4 (Taman Tasek Jaya)

\subsubsection{Data Collection in Construction Site \#5 (Putra Klebang)}

Six"6" electrical resistivity traverses, traverse no. 1 to traverse no.6 were controlled over and along the survey area in construction site \#5 which located in Putra Klebang to the northwest of Ipoh city. The direction of these profiles in $\left(\mathrm{N} 90^{\circ} \mathrm{W}\right)$, and the level of those lines are viewing in the Google earth satellite images in figure 30. Two dimensional (2-D) Electrical resistivity tomography (ERT) was carried out in this site by using 41-channel array in winner configuration. The length of each traverse was $200 \mathrm{~m}$, 
with an electrode spacing of $5.0 \mathrm{~m}$, and a space interval of about $25.0 \mathrm{~m}$ between each traverse.

The total length of all traverses in this site was $1200 \mathrm{~m}$, covering an area of $30000 \mathrm{~m} 2$. About 190 data points have composed for each (41-electrode) in one traverse, and on average, and about 1140 data were collected for a total of six traverses in this site.

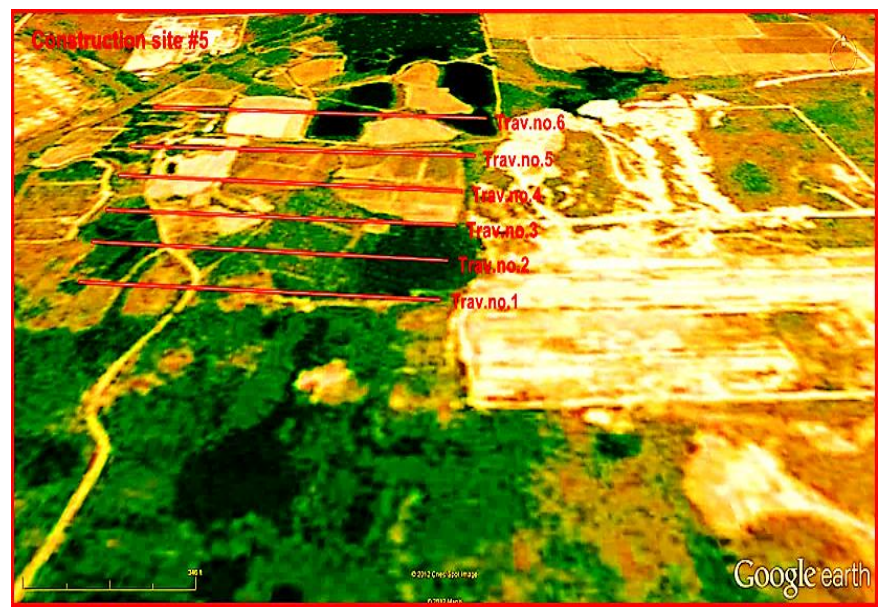

Figure 30: Google earth satellite image viewing the location of resistivity traverses in construction site \#5(Putra Klebang)

\section{DATA PROCESSING}

After completing the field survey, the resistance measurements are regularly converted to the apparent resistivity values. The data were developed to produce two dimensional resistivity models of the subsurface. This step is relating to convert the apparent resistivity values into a resistivity model section that can be using for the geological explanation. The data are readily obtains in the RES2DINV formats the conversion program was outfitted with system. The Root Mean Square (RMS) error statistics enumerate the distribution of the percentage differentiation between the logarithms of the calculated resistivity values and those calculated from the true resistivity model (calculated apparent resistivity values).

Data points with errors of more than $30 \%$ percent and above usually are detached. In this survey, a small RMS value indicates was less than $10 \%$ as defined by the convergence limit. The average default RMS error value in construction site\#1 is $3.74 \%$. The change in the RMS error between iterations with a minimum of $2.1 \%$ and a maximum of $5.1 \%$. The average default RMS error value in construction site\#2 is $7.95 \%$. The change in the RMS error between iterations with a minimum of $7.7 \%$ and a maximum of $9.0 \%$. The average default RMS error value in construction site\# 3 is $3.48 \%$. The change in the RMS error between iterations with a minimum of $3.2 \%$ and a maximum of $4.4 \%$. The average default RMS error value in construction site\#4 is $3.41 \%$. The change in the RMS error between iterations with a minimum of $2.5 \%$ and a maximum of $4.1 \%$. The average default RMS error value in construction site\#5 is $6.66 \%$. The change in the RMS error between iterations with a minimum of $4.0 \%$ and a maximum of $10.5 \%$.To get a good model, the data must be of uniformly good quality.

\section{The Bad data points fall into two broad categories or groups:}

Systematic noise is reasonably easy to detect in a data set as it is typically present in the limited number of readings, and the bad values frequently stick out, easily detached manually from the data set.

It's usually caused by some nature of collapse during the survey such that, the reading does not represent a true resistivity amount. This may due to many causes such as a break in the cable, very poor ground contact at an electrode so that inadequate current injected into the earth or forgetting to attach the clip to one of the electrodes and connecting the cables in the wrong way.

Haphazard noise includes things such as telluric currents that affect all the readings and the noise can cause the readings to be lower or higher than the corresponding noise-free readings. This noise is typically more familiar with arrays caused by the large distance linking the two potential electrodes P1electrode and electrode P2. This array tends to single out a large amount of telluric noise. When the noise is of a more arbitrary nature, the noisy data points are not as comprehensible, so it might not be functional to eliminate them manually. In addition, manually selection of the bad data points becomes impracticable if there are a large number of bad data points. In some cases, it is not feasible to display the data as simulated sections or profiles. As a common rule, before moving out the inversion of a data set, first take a glance at the data as a pseudo section plot as well as a profile plot. Additionally, in these fieldworks all the profiles that contain bad readings for the reason mentions above are redone.

\section{ANALYSIS AND INTERPRETATION OF ELECTRICAL RESISTIVITY TOMOGRAPHY/ IMAGES SECTIONS}

The ER Tomography technique applied in this geotechnical survey in order to imaging the shallow subsurface from a depth of less than $2.0 \mathrm{~m}$, to a maximum depth of $61.0 \mathrm{~m}$. This technique has used in the carbonate karst region as a function to investigate karst features such as sinkholes, cavities, depressions, and channel pipes. The survey found that this tool is suitable for differentiating surficial soil, clay, sand; weathered marbleized limestone bedrocks, intact marbleized limestone bedrocks and waterand air-filled cavities. In addition, it was applying due to its requiring less effort and more time effective. This technique based on the application of electric current into analyzed bedrock and measuring the intensity of electric resistivity to its passage. Basically, it gives information of electric resistivity properties through the analysis of material towards electrical current passage, Telford W.M. et al. (1990).

Several reports and researches on the application of geophysical techniques in many karst terrains, in several countries around the world, have reading. Anderson N. L. et 
al. (2007) do this research in (Assessment of Karst Activity at Highway Construction Sites Using the Electrical Resistivity Method, Missouri, USA).

Besides, additional research has done by Louis I.F. et al. (2002) of (Accurate subsurface characterization for highway applications by using resistivity inversion methods). Moreover, the research study in mining area in (Evaluating the presence of karst Bauxitic clays in parts of Western Desert of Iraq by the application of VLF - electromagnetic and Electrical resistivity techniques) by Yassin, R. (2002). In addition, the research by Zhou B.F.et al. (2000) in the Reliability of dipole-dipole Electrical resistivity tomography for defining depth to bedrock in covered karst terrains.

Furthermore, the research on; The application of complex geophysical techniques to detecting and locating the weakness zone and the water seepage in the body of the ALTharthar dam, Samara town, Salahuddin province / Iraq by Yahia N. A., Yassin, R. R., Hijab S. R. (1994). Finally, earlier research completed by Yahia, N. A., Yassin, R. R., Abdel Qadir, S. O.( 1992 ) in the application of 2D electrical resistivity and electromagnetic survey in study karst features and its deposits. These reports enabled the determination of the electrical variables associated with the nature of sediments.

Conclusions has made based on the variations in electrical resistivity values related to the nature of sediments. The geological classification permits the successful imaging of the bedrock and subsurface karst features, because soil, sand, clay, carbonate rock, and air-filled cavities can normally be differentiating and mapping.

\section{Clay}

It is usually distinguish by low apparent resistivity and variables, which are dependent on moisture, mineral content, purity, and unit shape/size, usually from 5 Ohm-m to less than $60 \mathrm{Ohm}-\mathrm{m}$. In this case, the clay has divided into many types with different colors, which has used in this resistivity section as:

- Highly moisturized soft clay is usually distinguished by insufficient low apparent resistivity, with waterfilled porosity or very high mineralized, usually from $3 \mathrm{Ohm}-\mathrm{m}$ to $5 \mathrm{Ohm}-\mathrm{m}$. In addition, sometimes contends radon gas in water. It has giving pink color in this study.

- Soft clay with pond water content is usually distinguish by extremely low resistivity and has very high conductivity or highly mineralized usually from 5Ohm-m to $10 \mathrm{Ohm}-\mathrm{m}$. Moreover, has giving dark blue color in this study.

- Moderate moisturized soft clay is usually distinguished by very low apparent resistivity and has very high conductivity or moderate mineralized, usually from $10 \mathrm{Ohm}-\mathrm{m}$ to less than $20 \mathrm{Ohm}-\mathrm{m}$. In addition, has giving light blue color in this studying.

- Clay with low-moisturized are usually distinguished by low apparent resistivity or with low mineralized content, usually from $20 \mathrm{Ohm}-\mathrm{m}$ to less than 50
Ohm-m. Moreover, has giving yellow color in this study.

Sand:

It is usually characterized by medium apparent resistivity and variables, depending on the moisture content, purity and unit size, usually from $70 \mathrm{Ohm}-\mathrm{m}$, to less than 160 Ohm-m. The sand is also dividing into many types; its coloring scheme described below:

- Sand, distinguished by medium apparent resistivity, usually from $100 \mathrm{Ohm}-\mathrm{m}$ to less than $160 \mathrm{Ohm}-\mathrm{m}$. Moreover, has giving dark green color in this study.

- Sandy clay, distinguished by its low medium apparent resistivity, usually from $70 \mathrm{Ohm}-\mathrm{m}$ to less than $100 \mathrm{Ohm}-\mathrm{m}$. Moreover, has giving light green color in this study.

\section{Weathered limestone rock:}

- Comparatively weathered limestone rock is typified by high apparent resistivities, typically more than $200 \mathrm{Ohm}-\mathrm{m}$, to less than $400 \mathrm{Ohm}-\mathrm{m}$, has given gray color in this study.

\section{Intact limestone rock:}

- Is distinguishing by higher apparent resistivity, naturally from more than $400 \mathrm{Ohm}-\mathrm{m}$ to more than 3000 Ohm-m, and varies depending on layer thickness, its impurities and moisture content. It has given a light purple colour in this study.

\section{Intact pure marbleized limestone or dolostone rocks:}

- Is distinguishing by higher apparent resistivity, naturally from more than $4000 \mathrm{Ohm}-\mathrm{m}$ to more than 8000 Ohm-m, and varies depending on layer thickness, its impurities and moisture content. It has given a dark purple colour in this study.

\section{$\underline{\text { Air-filled cavities or voids : }}$}

- Have generally characterized by very high apparent resistivity, usually more than 3000 Ohm-m to less than $6000 \mathrm{Ohm}-\mathrm{m}$, but varies depending on the conductivity of the nearby strata and size/shape of void or cavity. Classically, it has given a black color in this study.

\section{Transitional zone:}

- Mostly high-apparent resistivity (160) Ohm-m (200) Ohm -m, consists mostly of rock fragments and sand and or marly limestone. Classically, has given a Khaki color in this study.

\section{$\underline{\text { Radon : }}$}

- Radon gas has mostly found in karst area with unground features such as buried sinkholes, that containing water or underground caves and channels. Mostly has extremely very low -apparent 
resistivity from (1) Ohm-m - (3) Ohm $-\mathrm{m}$. it has given a pink color in this study.

Therefore, the electrical resistivity values were resolute for each rock unit. The results have tabulated in Table 2. This table was suitable for investigation karst features and its deposits within karst terrains. Also at the same time was suitable for detecting any mineral deposits within the sediments in the area but it need experience for that. The geological classification is utilized in this geoelectrical survey that was described above it permits the successful imaging of mapping and differentiated bedrocks and subsurface karstic features.

\begin{tabular}{|c|c|c|c|}
\hline So. & Range of resistiviţ values & Expected geological units deposits & $\begin{array}{l}\text { Color of Res, units } \\
\text { in ERT model }\end{array}$ \\
\hline 1. & $0 \Omega-m-5 \Omega-m$ & $\begin{array}{l}\text { Insufficient low resistivity;, Soft clay with water filled } \\
\text { porosity, very high mineralized. }\end{array}$ & \\
\hline 2. & $5 \Omega-\mathrm{m}-10 \Omega-\mathrm{m}$ & $\begin{array}{l}\text { Extremely low resistivity and very high conductivity, } \\
\text { softclay with ponded water, highly mineralized. }\end{array}$ & \\
\hline 3. & $10 \Omega-m-20 \Omega-m$ & $\begin{array}{l}\text { Very low resistivity and very high conductiviț, Clay } \\
\text { moderate mineralized. }\end{array}$ & \\
\hline 4. & $20 \Omega-m-50 \Omega-m$ & $\begin{array}{l}\text { Clay low mineralized, low resistivity and very high } \\
\text { conductivity. }\end{array}$ & \\
\hline 5. & $50 \Omega-m-70 \Omega-m$ & Below average resistivity, soil, silț or sandy clay. & \\
\hline 6. & $70 \Omega-m-100 \Omega-m$ & Arerage resistiviț; clayey or silț sand. & \\
\hline 7. & $100 \Omega-m-160 \Omega-m$ & Above average resistivity, sand friable, coarse grain. & \\
\hline 8. & $160 \Omega-m-200 \Omega-m$ & $\begin{array}{l}\text { Mostly high resistivity, transitional zone consists of } \\
\text { rock fragments and sand. }\end{array}$ & \\
\hline 9. & $>200 \Omega-m-400 \Omega-m$ & $\begin{array}{l}\text { high resistivity, weathered limestone, probably } \\
\text { consisting of wet joints or fractures and/or clay in- } \\
\text { fill, higher resistivity }\end{array}$ & \\
\hline 10. & $>400 \Omega-\mathrm{m}->3000 \Omega-\mathrm{m}$ & Verỵ high resistiviț, Compact or intact limestone. & \\
\hline 11. & $>3000 \Omega-\mathrm{m}-6000 \Omega-\mathrm{m}$ & Extremely high resistiviț; Voids or caviț; air in-fill. & \\
\hline 12. & $>6000 \Omega-\mathrm{m}-8000 \Omega-\mathrm{m}$ & $\begin{array}{l}\text { Extraordinarily high resistivity, Intact pure } \\
\text { marbleized limestone or dolostone rocks. }\end{array}$ & \\
\hline
\end{tabular}

Table 2: Describes the range of resistivity values with expect geological unit deposits to define the cave, cavity and sinkhole with air-infill

Because there is a crossing point between the value of resistivity data of intact limestone and the value of resistivities data to define karst features infill with air such as a cave, cavity, and sinkholes. The table above can be using for two times, one with resistivity from $3000-6000 \mathrm{Ohm}-\mathrm{m}$ to define the cave, cavity, and sinkhole with air-infill, table 2. In addition, to define rock fragments of limestone with friable and coarse grains sand which containing high porosity with air.

In the second time with resistivity from 3000-6000 Ohm $-\mathrm{m}$ as intact limestone, showed in table 3, without mentioning the void or cavity with air-infill.

\begin{tabular}{|c|c|c|c|}
\hline No. & Range of resistiviț ralues & Expected geological units deposits & $\begin{array}{l}\text { Color of Res. units } \\
\text { in ERT model }\end{array}$ \\
\hline 1. & $0 \Omega-m-5 \Omega-m$ & $\begin{array}{l}\text { Insufficient low resistiviț; Soft clay with water filled } \\
\text { porosiț, rerry high mineralized. }\end{array}$ & \\
\hline 2. & $5 \Omega-\mathrm{m}-10 \Omega-\mathrm{m}$ & $\begin{array}{l}\text { Extremely low resistivity and very high conductivity, } \\
\text { softclay with ponded water, highlỵ mineralized. }\end{array}$ & \\
\hline 3. & $10 \Omega-m-20 \Omega-m$ & $\begin{array}{l}\text { Tery low resistiviț̣ and verț high conductiviț, Clay } \\
\text { moderate mineralized. }\end{array}$ & \\
\hline 4. & $20 \Omega-m-50 \Omega-m$ & $\begin{array}{l}\text { Clay low mineralized, low resistiviț and very high } \\
\text { conductiviț. }\end{array}$ & \\
\hline 5. & $50 \Omega-m-70 \Omega-m$ & Below arerage resistiviț; soil, silț or sandỵ clạ. & \\
\hline 6. & $70 \Omega-m-100 \Omega-m$ & Arerage resistiviț̣, claỵẹ or silț̣ sand. & \\
\hline 7. & $100 \Omega-m-160 \Omega-m$ & Above average resistivity; sand friable, coarse grain. & \\
\hline 8. & $160 \Omega-m-200 \Omega-m$ & $\begin{array}{l}\text { Mostly high resistiviț, transitional zone consists of } \\
\text { rock fragments and sand. }\end{array}$ & \\
\hline 9. & $>200 \Omega-m-400 \Omega-m$ & $\begin{array}{l}\text { high resistiviț, weathered limestone, probably } \\
\text { consisting of wet joints or fractures and/or clay in- } \\
\text { fill, higher resistivity }\end{array}$ & \\
\hline 10. & $>400 \Omega-\mathrm{m}->3000 \Omega-\mathrm{m}$ & Veṛ̦ high resistiviț̣, Compact or intact limestone. & \\
\hline 11. & $>3000 \Omega-\mathrm{m}-6000 \Omega-\mathrm{m}$ & Verỵ high resistiviț, Compact or intact limestone. & \\
\hline 12. & $>6000 \Omega-m->8000 \Omega-m$ & $\begin{array}{l}\text { Extraordinarily high resistivity, Intact pure } \\
\text { marbleized limestone or dolostone rocks. }\end{array}$ & \\
\hline
\end{tabular}

Table 3: Describes the range of resistivity values with the expected geological unit deposits to define the weathered, intact limestone and intact marbleized limestone

In the following the analysis and interpretation of the data collected from resistivity profiles. The acquired data was interpreted by applying the geological classification originating from the variations in electrical resistivity values, which describes the range of resistivity values with the expected geological units' deposit. These classifications are the key interpretations of the geoelectrical data in order to understand the resistivity profiles and the function of sinkholes and other subsurface karstic features that investigated at these sites. In addition, this classifications has successfully used before for the exploration of mineral deposits in the karst area, Yassin, R.R. (2002). The interpretation of resistivity data identifies the points illustrated in the objective of the study.

The smoothing that observed in the subsurface limestone bedrock is the result of employing the RES2DINVER.3.54. Software, which assumes that the subsurface is uniform, layered; and consequently lateral smoothing will form in a non-layered stratum. Some of the boreholes have completed by auger to the depth of $10 \mathrm{~m}$ at some point, facilitating in the interpretation of covered sediments in these sites. The high contrast in resistivity values between the carbonate rocks and the clayey soil is favorites to the use of the geo-electrical resistivity method to delineate the boundary between bedrocks and overburden. The Wenner arrays provide the highest resolution, and are most sensitive to vertical resistivity boundaries found at pinnacles and gutter interfaces.

However, the data collected from the Wenner array are sensitive to near-surface resistivity variations, Griffiths \& Barker, (1993), and therefore can produce noisy data. 
Computerized instrumentation permits automatic selection of four electrodes from a multiple-electrode array to use for each measurement, which significantly expedites the data collection process. The measuring of apparent resistivity is volume-averaged values that had affected by all the geologic layers, through which the induced electric current flows. An inversion program converts the array of apparent resistivity data into a model of the geology that would yield the observed distribution of the apparent resistivity values. The product of the data inversion process is a 2-D image.

The extensive description of the classification described above is the key to the interpretations of the geological survey that had carried out to understand the resistivity profiles and the function of sinkholes and other investigated subsurface karstic features. The interpretation of the resistivity data in the absence of borehole control in the area was relatively complex. Some of boreholes has completed by auger reaching the depth of $\sim 10 \mathrm{~m}$. At some point, it facilitates the interpretation of covered sediments in these sites.

\subsection{The Interpretation of E.R. Tomography Sections in Construction Site \#1 (Taman Batu Gagah Perdana)}

The electrical resistivity data of this construction site\#1 were building up in electric resistivity tomography sections. The interpretations of Tomography or image sections have clarified by applying of table 2 and table 3 above in the absence of borehole control. The inverse model of electrical resistivity sections from traverses no.1 to traverse no. 4 present in figure, 31 (A-D) were viewing the interpreted location of shallow karst features (sinkholes and cavities) in construction site\#1 (Taman Batu Gagah Perdana).

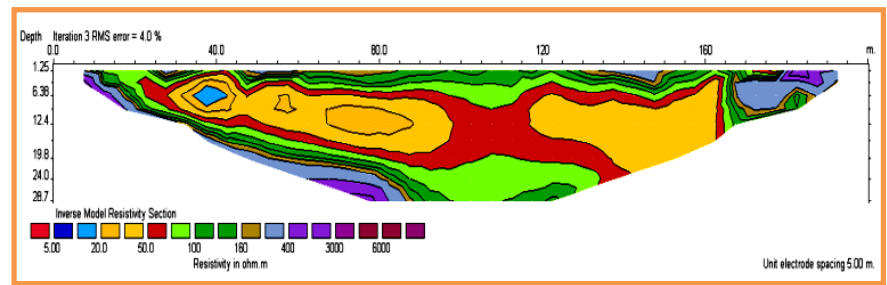

(Figure31 - A) The Inverse model of electrical resistivity section for Traverse no.1 (Taman Batu Gagah Perdana)

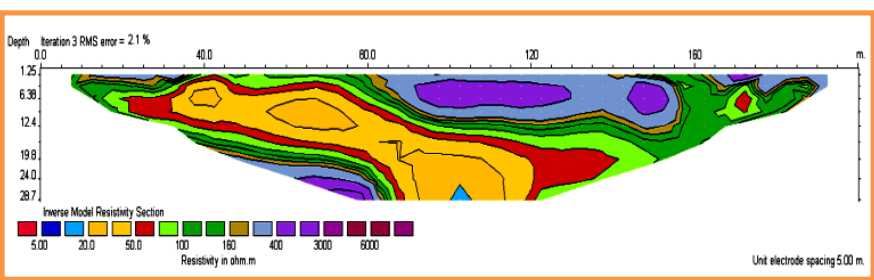

(Figure31 - B) The Inverse model of electrical resistivity section for Traverse no.2 (Taman Batu Gagah Perdana)

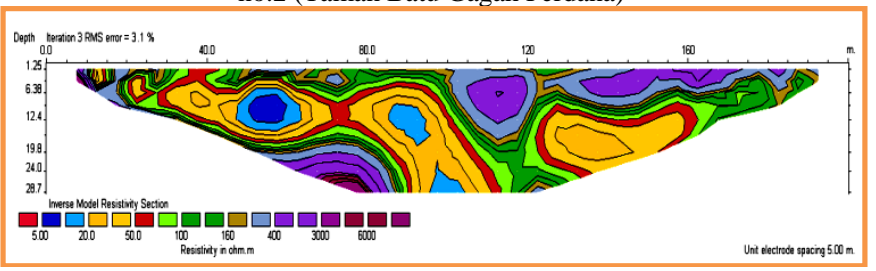

Figure31 - C) The Inverse model of electrical resistivity section for Traverse no.3 (Taman Batu Gagah Perdana)

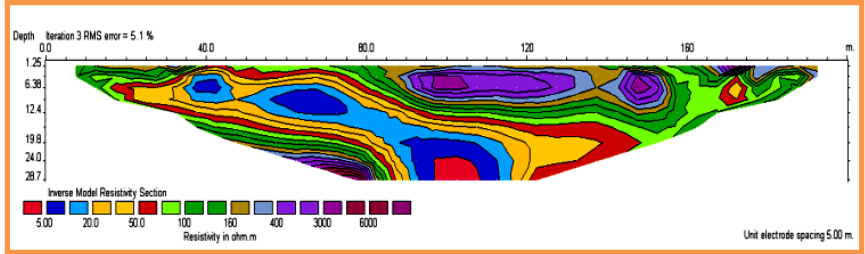

(Figure31 - D) The Inverse model of electrical resistivity section for Traverse no.4 (Taman Batu Gagah Perdana)

Figure 31(A-D): The Inverse model of electrical resistivity section from Traverses no. 1 - Traverses no. 4 viewing the interpreted location of shallow karst features (sinkholes and cavities) in construction site\#1 (Taman Batu Gagah Perdana)

The database of karst features from (2-D) E R Tomography sections in construction site\#1 (Taman Batu Gagah Perdana) has viewed in table 4.

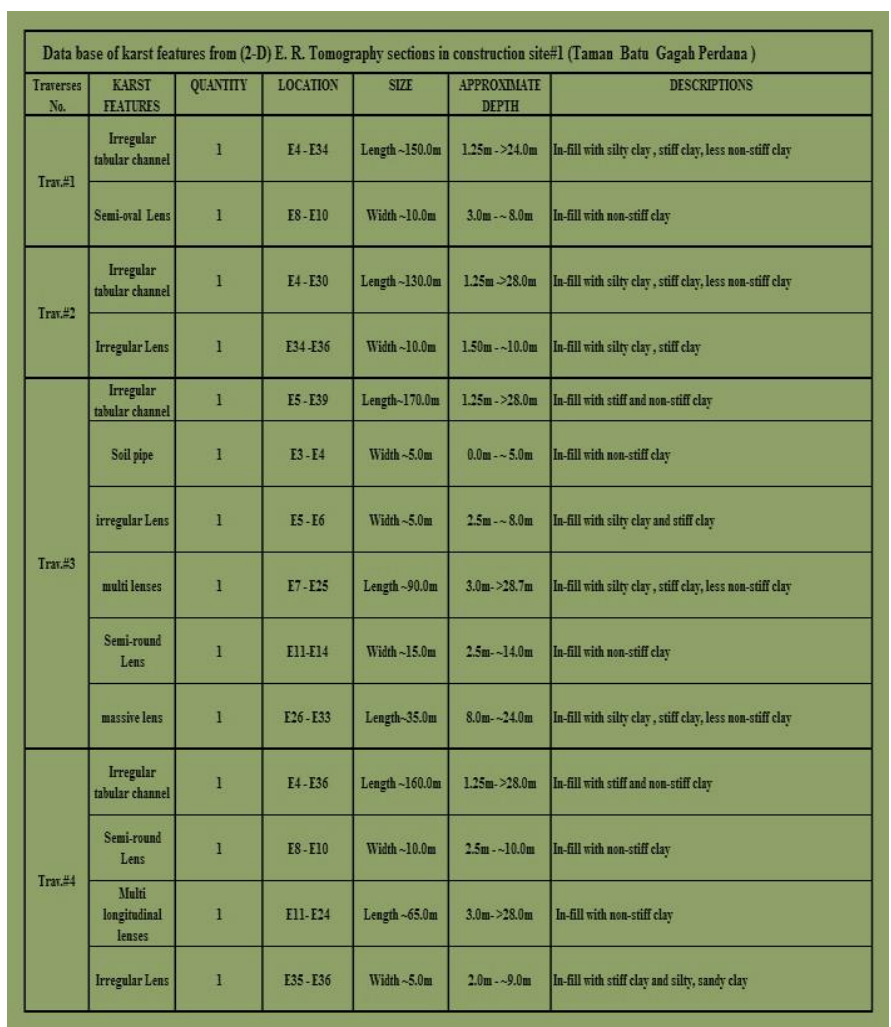

Table 4: The database of karst features from (2-D) E R Tomography sections in construction site\#1 (Taman Batu Gagah Perdana)

\subsection{The Interpretation of E.R. Tomography Sections in Construction Site\#2 (Gunung Rapat)}

The electrical resistivity data of this construction site\#2 were building up in electric resistivity tomography sections. The interpretations of Tomography or image sections have clarified by applying of table 2 and table 3 above in the absence of borehole control.

The inverse model of electrical resistivity sections from traverses no. 1 to traverses no.4 in figure 32(A-D), viewing the interpreted location of shallow karst features (sinkholes and cavities) in construction site\#2 (Gunung Rapat). 


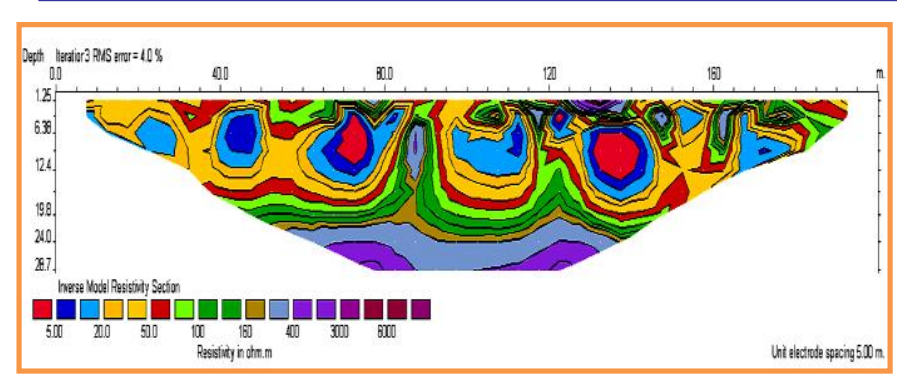

Figure(32 - A) The inverse model of electrical resistivity section for Traverse no.1 (Gunung Rapat)

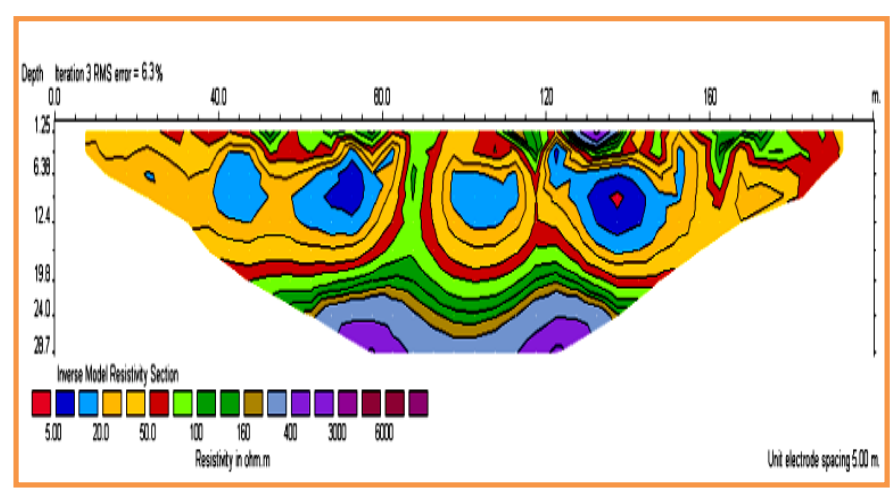

Figure(32 - B) The inverse model of electrical resistivity section for Traverse no.2 (Gunung Rapat)

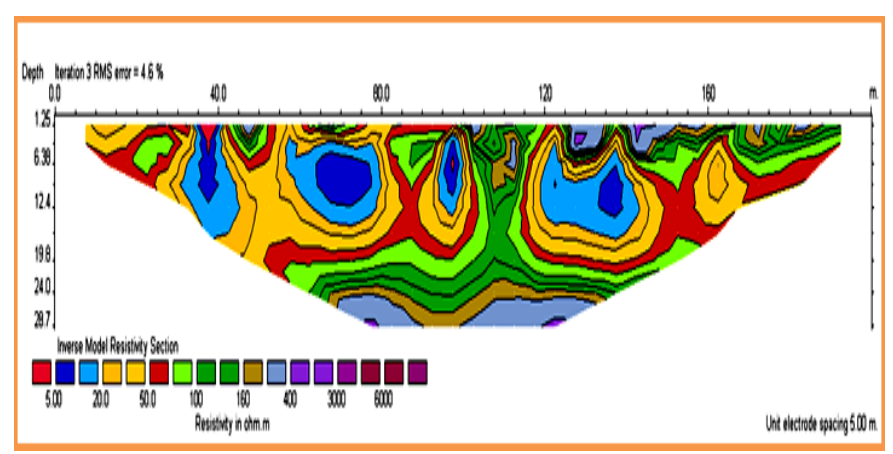

Figure(32 - C) The inverse model of electrical resistivity section for Traverse no.3 (Gunung Rapat)

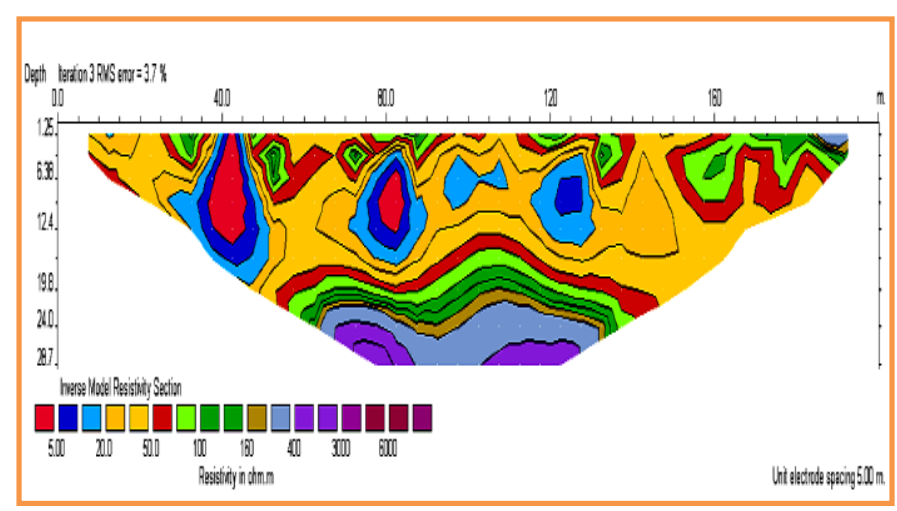

Figure(32- D) The inverse model of electrical resistivity section for Traverse no.4 (Gunung Rapat)

Figure 32(A-D): The Inverse model of electrical resistivity section from Traverses no. (1 -4), viewing the interpreted location of shallow karst features (sinkholes and cavities) in construction site\#2 (Gunung Rapat)
The database of karst features from (2-D) E R Tomography sections in construction site\#2 (Gunung Rapat) has viewed in table 5 .

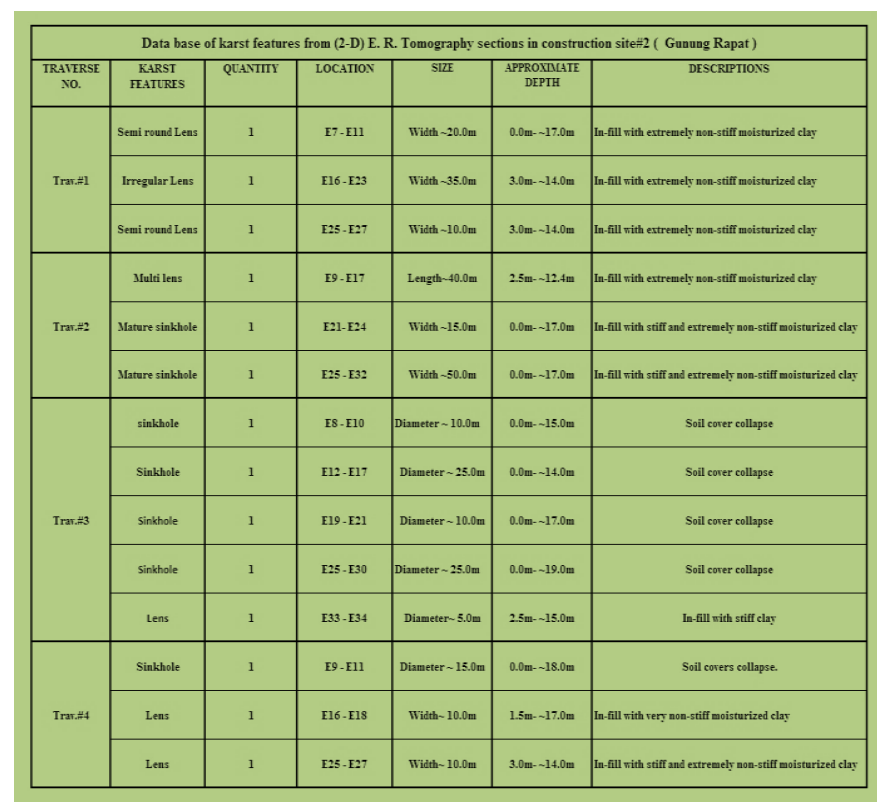

Table 5: The database of karst features from (2-D) E R Tomography sections in construction site\#2 (Gunung Rapat)

\subsection{The Interpretation of E.R. Tomography Sections in construction site \#3 (Taman Tasek Indra - Ipoh city)}

The electrical resistivity data build up in electric resistivity tomography sections in this construction site\#3. The interpretations of Tomography or image sections have clarified by applying of table 2 and table 3 above in the absence of borehole control.

The inverse model of electrical resistivity section from Traverses no. 1 to traverse no. 3 in figure 33(A-C) were viewing the interpreted location of shallow karst features (sinkholes and cavities) in construction site\#3 (Tesco Extra Ipoh).

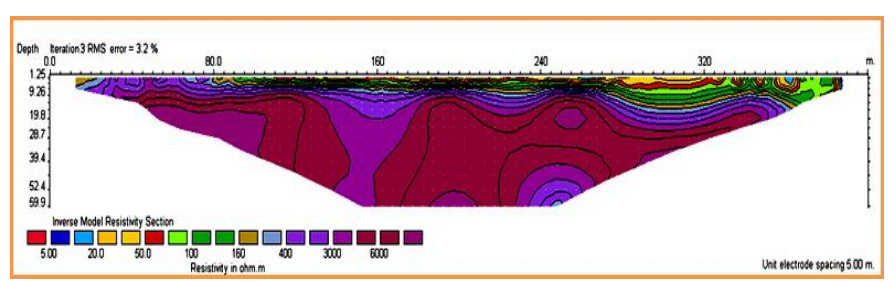

Figure (33 - A): The inverse model of electrical resistivity section for Traverse no. 1 (Tesco Ipoh City)

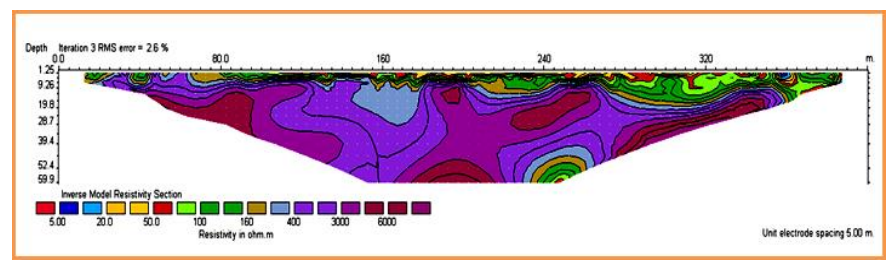

Figure (33 - B): The inverse model of electrical resistivity section for Traverse no. 2 (Tesco Extra-Ipoh City) 


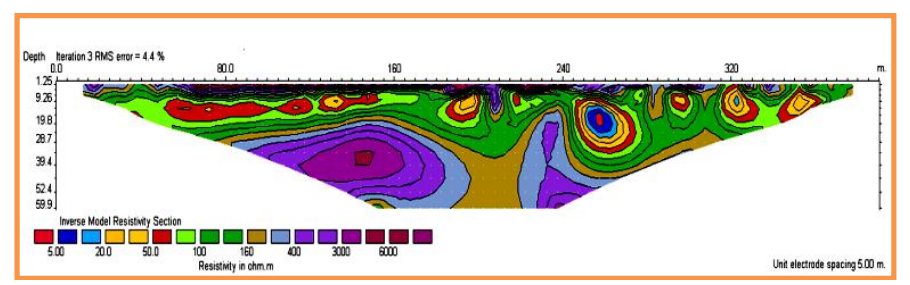

Figure (33 - C): The inverse model of electrical resistivity section for Traverse no. 3(Tesco Extra- Ipoh City)

Figure 33(A-C): Inverse model of electrical resistivity section from Traverses no. (1 -3), viewing the interpreted location of shallow karst features (sinkholes and cavities) in construction site\#3(Tesco Extra Ipoh)

The database of karst features from (2-D) E R Tomography sections in construction site\#3(Tesco Extra-Ipoh City) has viewed in table 6 .

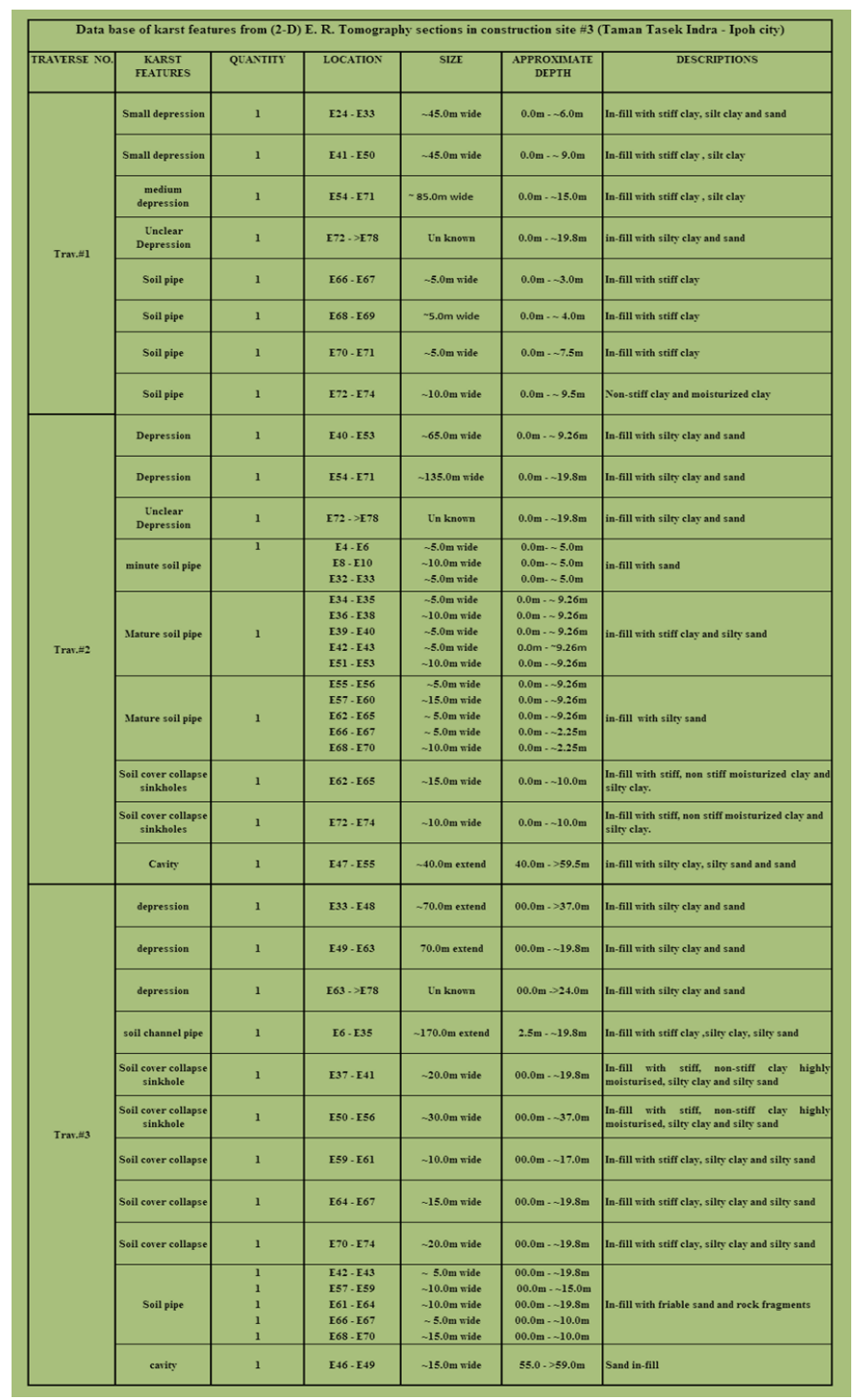

Table 6: The data base of karst features from (2-D) E R Tomography sections in construction site\#3(Tesco Extra-Ipoh City)

\subsection{The Interpretation of E.R. Tomography Sections in Construction Site \#4 (Taman Tasek Jaya)}

The electrical resistivity data of this construction site\#4 were building up in electric resistivity tomography sections. The interpretations of Tomography or image sections have clarified by applying of table 2 and table 3 above in the absence of borehole control. The inverse model of electrical resistivity sections form traverse no. 1 to traverse no.4 in figure $34(\mathrm{~A}-\mathrm{D})$ were viewing the interpreted location of shallow karst features (sinkholes and cavities) in construction site\#4(Taman Tasek Jaya).

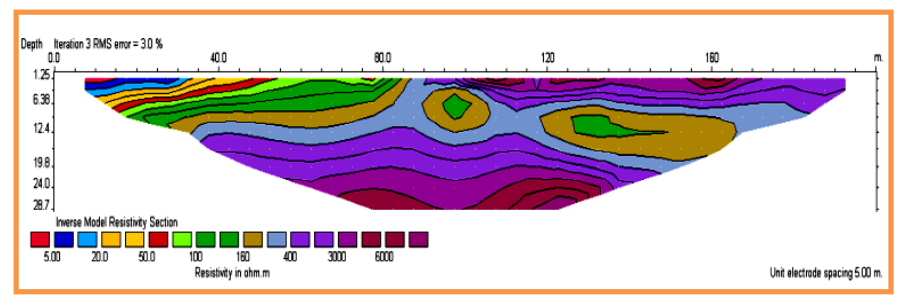

Figure (34 - A): The inverse model of electrical resistivity section for Traverse no. 1 (Taman Tasek Jaya)

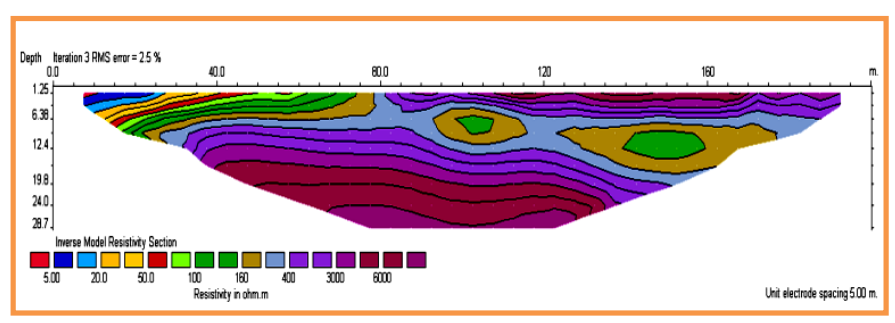

Figure (34- B): The inverse model of electrical resistivity section for Traverse no. 2 (Taman Tasek Jaya)

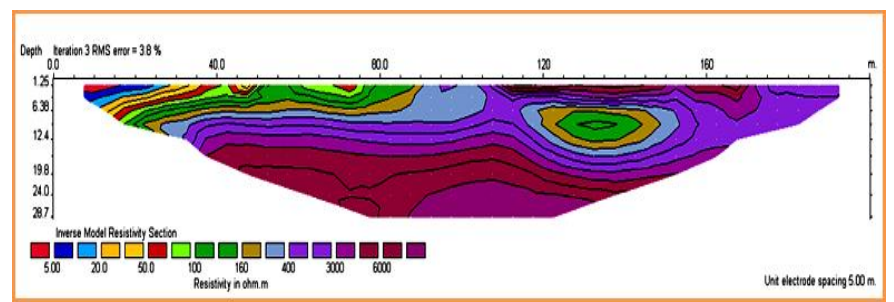

Figure (34 - C): The inverse model of electrical resistivity section for Traverse no. 3 (Taman Tasek Jaya)

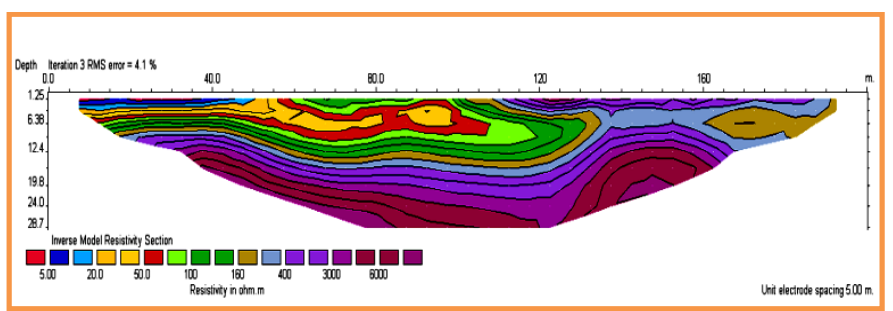

(Figure34 - D): The inverse model of electrical resistivity section for Traverse no. 4 (Taman Tasek Jaya)

Figure 34(A-D): Inverse model of electrical resistivity section from Traverses no. (1 -4), viewing the interpreted location of shallow karst features (sinkholes and cavities) in in construction site\#4(Taman Tasek Jaya).

The data base of karst features from (2-D) E R Tomography sections in construction site\#4(Taman Tasek Jaya) has viewed in table 7 . 


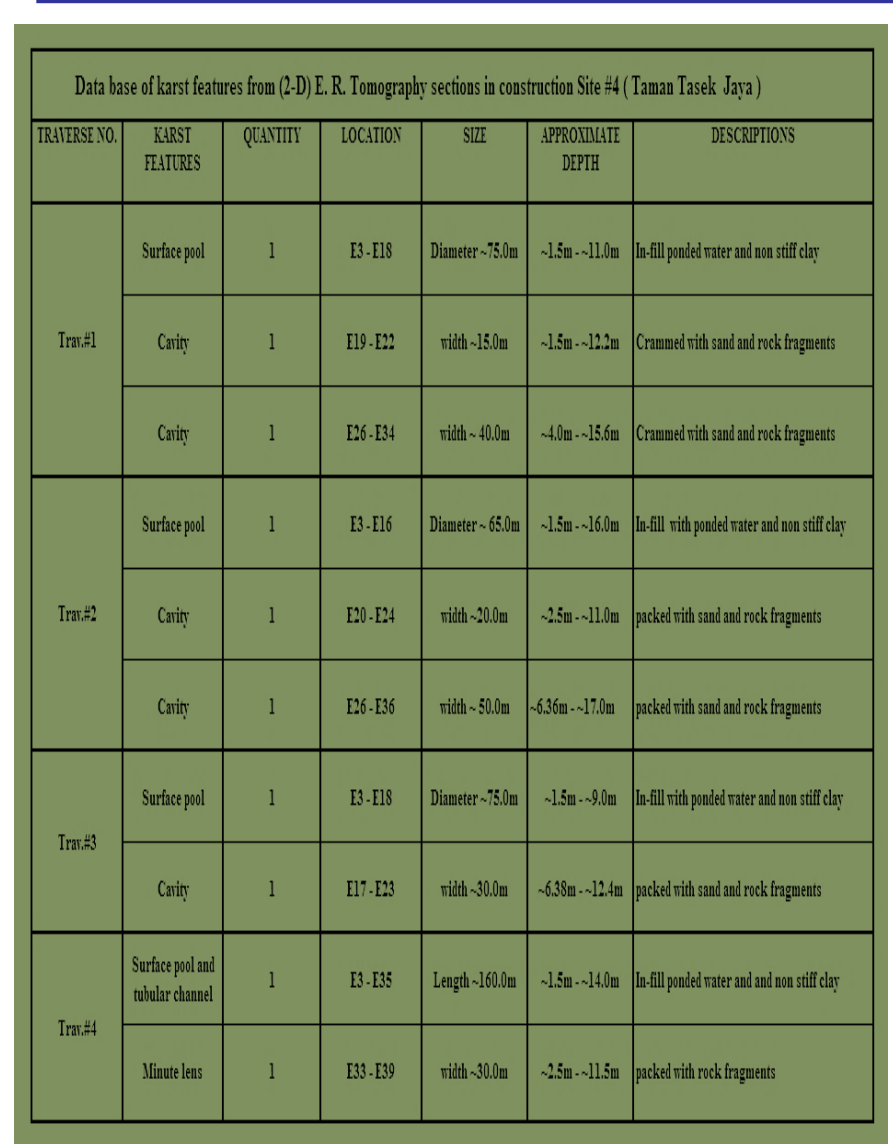

Table 7: The database of karst features from (2-D) E R Tomography sections in construction site\#4 (Taman Tasek Jaya)

\subsection{The Interpretation of E.R. Tomography Sections in Construction Site \#5 (Klebang Putra)}

The electrical resistivity data of this construction site\#5 were building up in electric resistivity tomography sections. The interpretations of Tomography or image sections have clarified by applying of table 2 and table $\mathbf{3}$ above in the absence of borehole control. The inverse model of electrical resistivity sections form traverse no.1 to traverse no.6 in figure 35(A-F) were viewing the interpreted location of shallow karst features (sinkholes and cavities) in Construction site \#5 (Klebang Putra).

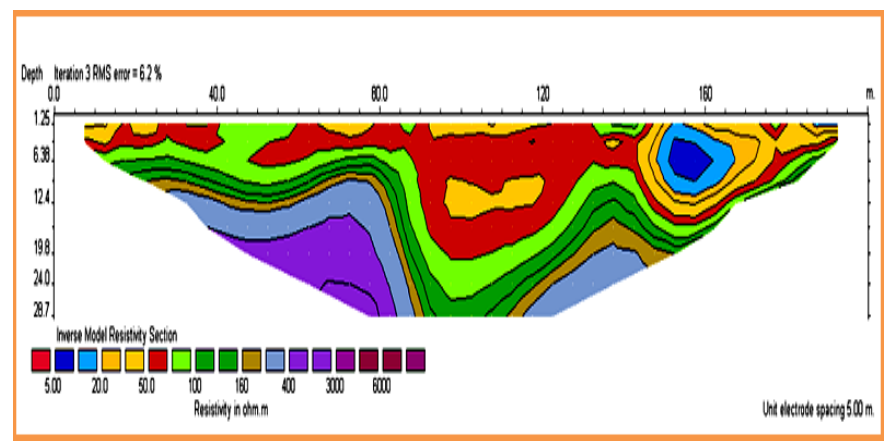

Figure (35 - A): The inverse model of electrical resistivity section for profile no. 1 (Klebang Putra)

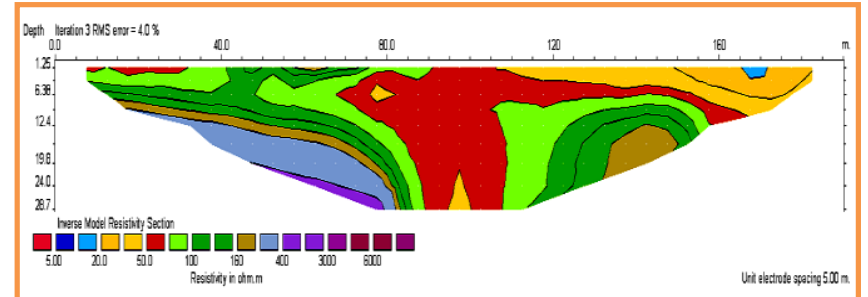

Figure (35- B): Inverse model of electrical resistivity section for profile no. 2 (Klebang Putra)

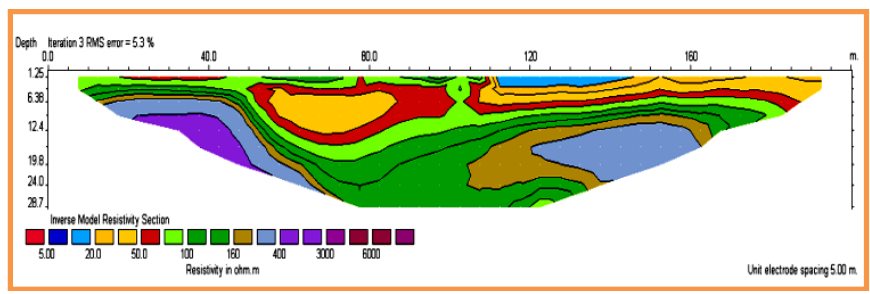

Figure (35 - C): Inverse model of electrical resistivity section for profile no. 3 (Klebang Putra)

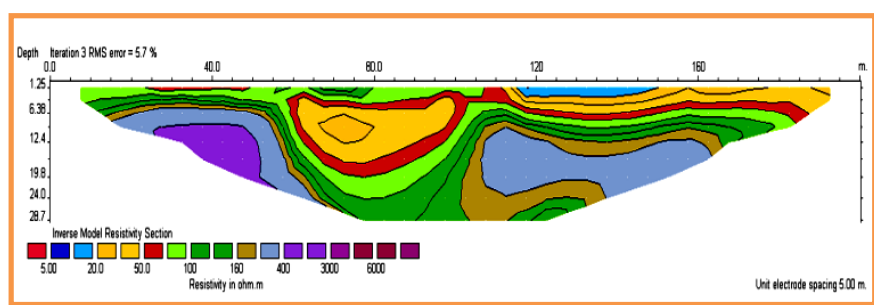

Figure (35-D): Inverse model of electrical resistivity section for profile no. 4 (Klebang Putra)

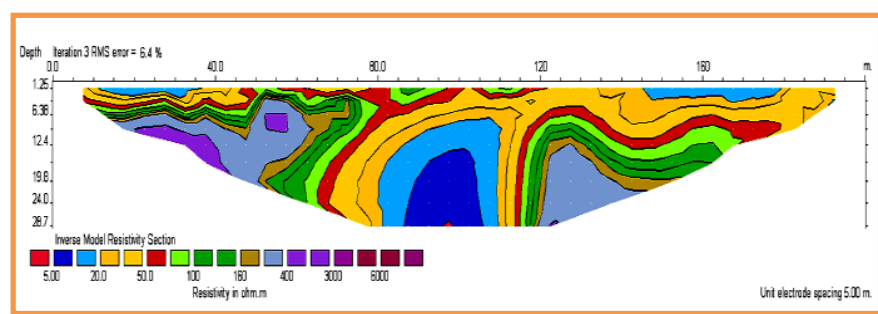

Figure (35- E): Inverse model of electrical resistivity section for profile no. 5 (Klebang Putra)

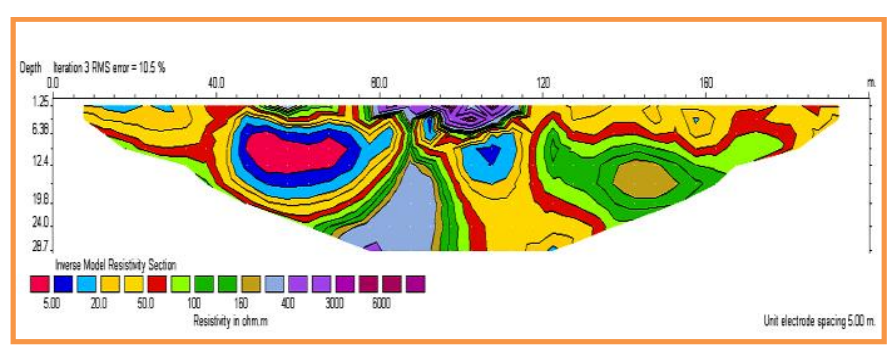

Figure (35 - F): Inverse model of electrical resistivity section for profile no. 6 (Klebang Putra)

Figure 35(A-F): Inverse model of electrical resistivity section from traverse no. 1 to traverse no.6, viewing the interpreted location of shallow karst features (sinkholes and cavities) in Construction site \#5 (Klebang Putra)

The database of karst features from (2-D) E R Tomography sections in construction site \#5(Klebang Putra) has viewed in table 8. 


\begin{tabular}{|c|c|c|c|c|c|c|}
\hline \multicolumn{7}{|c|}{ Data base of karst features from (2-D) E. R. Tomography sections in construction site \# 5 (Taman Klebang Putra) } \\
\hline 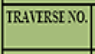 & $\begin{array}{c}\text { KARST } \\
\text { KAAIRSS }\end{array}$ & QTANIITI & LOCATION & SIII & \begin{tabular}{|l|} 
APROOXIATIT \\
DEPTH \\
\end{tabular} & DESCRPPIONS \\
\hline \multirow{2}{*}{ Tras:=1 } & Sinksale & 1 & [17:228 & Dimeter 5 55:0u & $-1.25 \mathrm{~m}>28.7 \mathrm{~m}$ & 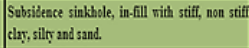 \\
\hline & Lens & 1 & E30:536 & Wisth $30.0 \mathrm{~m}$ & $22.25 \mathrm{~m}-12.24 \mathrm{~m}$ & 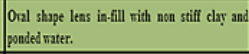 \\
\hline Irrat:2 & Sinktole & 1 & E15:28 & Dimeter 6550 . & $-1.25 \mathrm{~m} \cdot 28 \mathrm{28} \mathrm{m}$ & 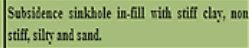 \\
\hline \multirow{2}{*}{ Irrat:3 } & Sinkhale & 1 & E10:527 & Dimeter -8550 m & $-1.22 \mathrm{~m}-240 \mathrm{~m}$ & 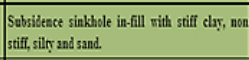 \\
\hline & Smull Depress & 1 & E3:300 & Lenghr -350 out & $-1.50 \mathrm{~m}-9.0 \mathrm{~m}$ & In-fill rith non stifi mad stiff cly. \\
\hline \multirow{2}{*}{ Irri:4 } & Sinkbsale & 1 & E12:23 & Dimeter -550 . & $-1.25 \mathrm{~m} \rightarrow 24.0 \mathrm{~m}$ & 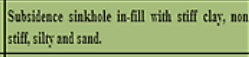 \\
\hline & Sunll Depress & 1 & E24:531 & Lenght 35 .0um & $-1.50 \mathrm{~m}-11.0 \mathrm{~m}$ & 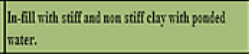 \\
\hline \multirow{2}{*}{ Irrats } & Sinkhale & 1 & E16:226 & riidth $\sim 50.0 \mathrm{~m}$ & $-1.26 \mathrm{~m}-28.7 \mathrm{~m}$ & 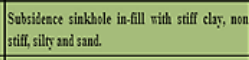 \\
\hline & Senll Depress & 1 & E27:534 & Lengh $>3500$ m & $\sim 0.0 \mathrm{~m}-12.24 \mathrm{u}$ & 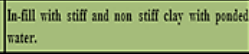 \\
\hline \multirow{5}{*}{ Trum:6 } & Sinkhale & 1 & E18:526 & Dimerter 350 & $-1.25 \mathrm{~m}-28 \mathrm{28 \textrm {m }}$ & 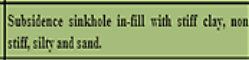 \\
\hline & Lens & 1 & E10:H18 & ridth $40.0 \mathrm{~m}$ & $-1.25 \mathrm{~m}-2.30 \mathrm{~m}$ & 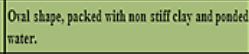 \\
\hline & Lens & 1 & E24:27 & ridith-150m & $-4.50 \mathrm{u}-18.00 \mathrm{~m}$ & 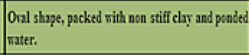 \\
\hline & Cairy & 1 & E25:534 & ridith 4 450m & $-11.0 \mathrm{ln}-15 \mathrm{150 \textrm {m }}$ & Praked rith reck frggunats. \\
\hline & Depression & 1 & E26:535 & Lenght 4 -5:0u & 0.0m $-9.0 \mathrm{ma}$ & |lin.fll rith silf dy. \\
\hline
\end{tabular}

Table8: The database of karst features from (2-D) E R Tomography sections in construction site \#5(Klebang Putra)

\section{Descriptions of boreholes from the geological boring reports}

The boring report by auger clarified that the auger has penetrated until maximum depth of $12.0 \mathrm{~m}$ of layers described as; Soil, clay, silty sand, sand, marbleized limestone rock fragments. Sometimes was penetrated faster in layers described as soil and very non-stiff clay highly moisturized. Besides, the boring report by auger clarified that the auger many times was terminated in a Boulders and fragment of marbleized limestone rocks.

Through the comparison between the boring data by auger and geophysical data found that there is small deference in the depth between the depth from geophysical interpretation sections and the depth from the geological report of drilling by auger about $2.0 \mathrm{~m}$ to maximum $5.0 \mathrm{~m}$ if the ground surface cover with sand and/or rock fragments. The boring report clarified the boreholes which drilled by auger in site\#1, \#2, \#3, \#4 and site \#5were described in table9(A,B,C,D,E) below.

\begin{tabular}{|c|c|c|c|c|c|c|}
\hline \multicolumn{7}{|c|}{$\begin{array}{l}\text { Description of boreholes drilled by Auger in construction site\# } 1 \\
\text { (Batu Gagah -Taman Batu Gagah Perdana) }\end{array}$} \\
\hline $\begin{array}{c}\text { Borehole } \\
\text { no. }\end{array}$ & $\begin{array}{c}\text { Traverse } \\
\text { no. }\end{array}$ & Dilling position & $\begin{array}{l}\begin{array}{l}\text { Depth from } \\
\text { drilling by }\end{array} \\
\end{array}$ & \begin{tabular}{|c} 
Depth from ERT \\
sections
\end{tabular} & Description & Check point \\
\hline 1 & 1 & E. 5 & $7.0 \mathrm{~m}$ & $6.38 \mathrm{~m}$ & $\begin{array}{l}\text { Soil, silty sand, sand, marbleized limestone, } \\
\text { rock fragments. }\end{array}$ & Boundary of rock fragments \\
\hline 2 & 2 & E-9 & 16.5m & 14.5m & \begin{tabular}{|l|} 
Soill with rarious quantities of sand, \\
Boulders and fragment of marbleized
\end{tabular} & Narblized limestone bedrock \\
\hline 3 & 3 & E-17 & $16.0 \mathrm{~m}$ & 15.0m & $\begin{array}{l}\text { Soil and rery non siff clay highly } \\
\text { moisturized. }\end{array}$ & Layer of sand \\
\hline 4 & 4 & $\mathrm{E}-23$ & $17.0 \mathrm{~m}$ & $16.0 \mathrm{~mm}$ & \begin{tabular}{|l|} 
Soll with rarious guantities of sand, stiff \\
clay, no siff clay highly moisturized.
\end{tabular} & Non siff Noisturized clay \\
\hline
\end{tabular}

Table 9-A: Boring report clarified the boreholes which drilled by auger in construction site\#1

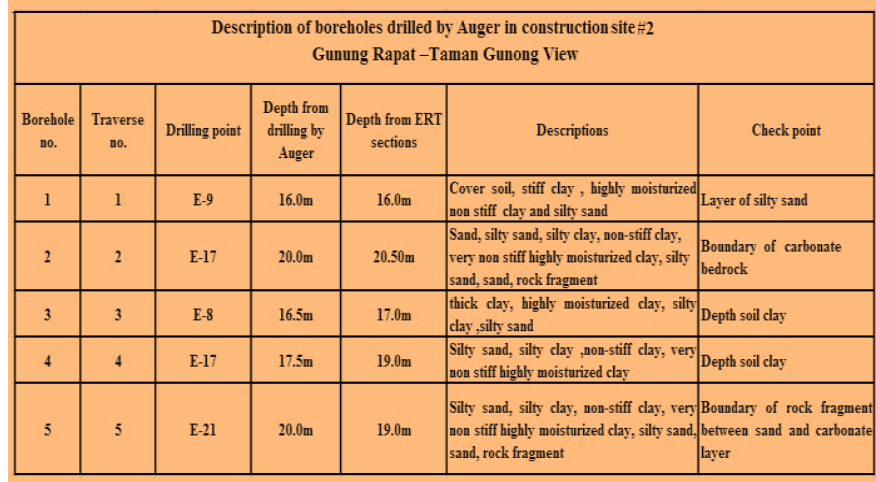

Table 9-B: Boring report clarified the boreholes which drilled by auger in construction site\#2

\begin{tabular}{|c|c|c|c|c|c|c|}
\hline \multicolumn{7}{|c|}{$\begin{array}{l}\text { Description of boreholes drilled by Auger in construction site \#3 } \\
\text { (Ipoh Ciț-Taman Task Indra) }\end{array}$} \\
\hline Boreblele no. & Traresse no. & $\begin{array}{l}\text { Dirlling } \\
\text { position }\end{array}$ & \begin{tabular}{|c|}
$\begin{array}{c}\text { Depth from dirlling } \\
\text { by Anger }\end{array}$ \\
\end{tabular} & \begin{tabular}{|c|} 
Depth from ER \\
Tomography sections \\
\end{tabular} & Descripion & Check point \\
\hline 1 & 1 & E-62 & 14.5m & 14.0m & $\begin{array}{l}\text { Soil, stiff clay, silty clay, silty } \\
\text { sand, sand, rock fragments. }\end{array}$ & $\begin{array}{l}\begin{array}{l}\text { Boundary of rock } \\
\text { fraggnents }\end{array} \\
\end{array}$ \\
\hline 2 & 2 & E-19 & 6.0m & 60m & $\begin{array}{l}\text { Thin crust of soil, sand, rock } \\
\text { fraggments. }\end{array}$ & $\begin{array}{l}\begin{array}{l}\text { Boundary of rock } \\
\text { fraggents }\end{array} \\
\end{array}$ \\
\hline 3 & 3 & E-48 & 10.0m & $9.62 \mathrm{~m}$ & $\begin{array}{l}\text { Thin crust of soil, sand, rock } \\
\text { fragments, marblized Lst. }\end{array}$ & Depth of pinade \\
\hline
\end{tabular}

Table 9-C: Boring report clarified the boreholes which drilled by auger in construction site\#3

\begin{tabular}{|c|c|c|c|c|c|c|}
\hline \multicolumn{7}{|c|}{ Description of boreholes drilled by Auger in construction site $\#$ \#4 } \\
(Taman Tasek Jaya)
\end{tabular}

Table 9-D: Boring report clarified the boreholes which drilled by auger in construction site\#4

\begin{tabular}{|c|c|c|c|c|c|c|}
\hline \multicolumn{7}{|c|}{$\begin{array}{l}\text { Description of boreholes drilled bv Auger in construction site } \# 5 \\
\text { (Taman Klebang putra) }\end{array}$} \\
\hline Borebole no. & Traverse no. & \begin{tabular}{|l|l|} 
Dilling point \\
\end{tabular} & \begin{tabular}{|c|} 
Depth from dirling \\
by Anger
\end{tabular} & \begin{tabular}{|c|} 
Depth from $\mathrm{ER}$ \\
Tomography sections
\end{tabular} & Description & Check points \\
\hline 1 & 1 & E.22 & $12.0 \mathrm{~m}$ & 12.4m & Stiff clay, silty clay. & Siff organic gray clay \\
\hline 2 & 3 & E-17 & $6.0 \mathrm{~m}$ & $6.36 \mathrm{~m}$ & Soil, silty sand, silty clay. & Sifif organic gray clay \\
\hline 3 & 5 & E-21 & 12.0m & 12.4m & $\begin{array}{l}\text { Soil, stiff clay, silty clay, highth. } \\
\text { moisturized clay. }\end{array}$ & Lens \\
\hline 4 & 6 & E-1l & $6.3 \mathrm{~m}$ & $5.6 \mathrm{~m}$ & $\begin{array}{l}\text { Soil, sfiff clay, silty clay, highth } \\
\text { moisturized clay. }\end{array}$ & $\begin{array}{l}\text { Lens rith highly } \\
\text { moisturized day }\end{array}$ \\
\hline
\end{tabular}

Table 9-E: Boring report clarified the boreholes which drilled by auger in construction site\#5

Table -9(A-E): Viewing the descriptions of boreholes which drilled by auger in construction site\#1, site \#2, site\#3, site \#4, and site \#5

\section{The depth of marbleized limestone bedrocks in the study construction sites}

Contiguous karst terrains normally create problems for civil engineers. Often, only engineers who are familiar 
with soluble rock understand these anomalies and problems that are associated with it. For engineers, limestone creates various difficulties that are made complexity by increased expansion of the karsts morphology.

The tables below present an outline or portrayal of some selected points regarding the limestone bedrock depth of the five construction sites that will be favourable for engineers for them to recognize the depth of limestone in these selected construction sites under studies. These are, however, incomplete and can only provide common suggestions of projected ground conditions, despite the possibility of ending up with enormous discrepancies regarding the depth of the local features.

The surveys showed that the depth of marbleized limestone bedrock in these construction sites was uneven or asymmetrical, and possesses many Pinnacles and Gutters. Table 10-A, B, C, D and E described the approximate depths of weathered, intact marbleized limestone bedrock and pinnacles in the selected construction sites through the interpretation of inverse model sections.

In construction site $\# 1$, the depth of weathered limestone bedrock was mixed between $17.0 \mathrm{~m}$ and $>28.0 \mathrm{~m}$. For intact limestone bedrock, the depth varied between 22.0 $\mathrm{m}$ and $>28.0 \mathrm{~m}$, and the depth of pinnacles varied between $17.0 \mathrm{~m}$ and $24.0 \mathrm{~m}$, as shown in Table 10-A.

In construction site \#2, the depth of weathered limestone bedrock mottled between $20 \mathrm{~m}$ and $>28.0 \mathrm{~m}$. The depth of an intact limestone bedrock varied between $21.0 \mathrm{~m}$ and $>28.0 \mathrm{~m}$, while the depth of its pinnacles varied between $20.0 \mathrm{~m}$ and $27.0 \mathrm{~m}$, as shown in Table 10-B.

In construction site \#3, the depth of weathered limestone bedrock mottled between $3.00 \mathrm{~m}$ and $28.0 \mathrm{~m}$. The depth of intact limestone bedrock varied between $6.0 \mathrm{~m}$ and $>28.0 \mathrm{~m}$, and the depth of pinnacles varied between $5.0 \mathrm{~m}$ and $12.0 \mathrm{~m}$, as shown in Table 10-C.

In construction site \#4, the depth of weathered limestone bedrock mottled between $1.50 \mathrm{~m}$ and $12.4 \mathrm{~m}$. The depth of intact limestone bedrock varied between $1.50 \mathrm{~m}$ and $22.0 \mathrm{~m}$, and the depth of pinnacles unclear in this site , as shown in Table 10-D.

In construction site \#5, the depth of weathered limestone bedrock mottled between $3.00 \mathrm{~m}$ and $>28.0 \mathrm{~m}$. The depth of intact limestone bedrock varied between $8.0 \mathrm{~m}$ and $>28.0 \mathrm{~m}$, and the depth of pinnacles varied between $3.0 \mathrm{~m}$ and $19.0 \mathrm{~m}$, as shown in Table 10-E.

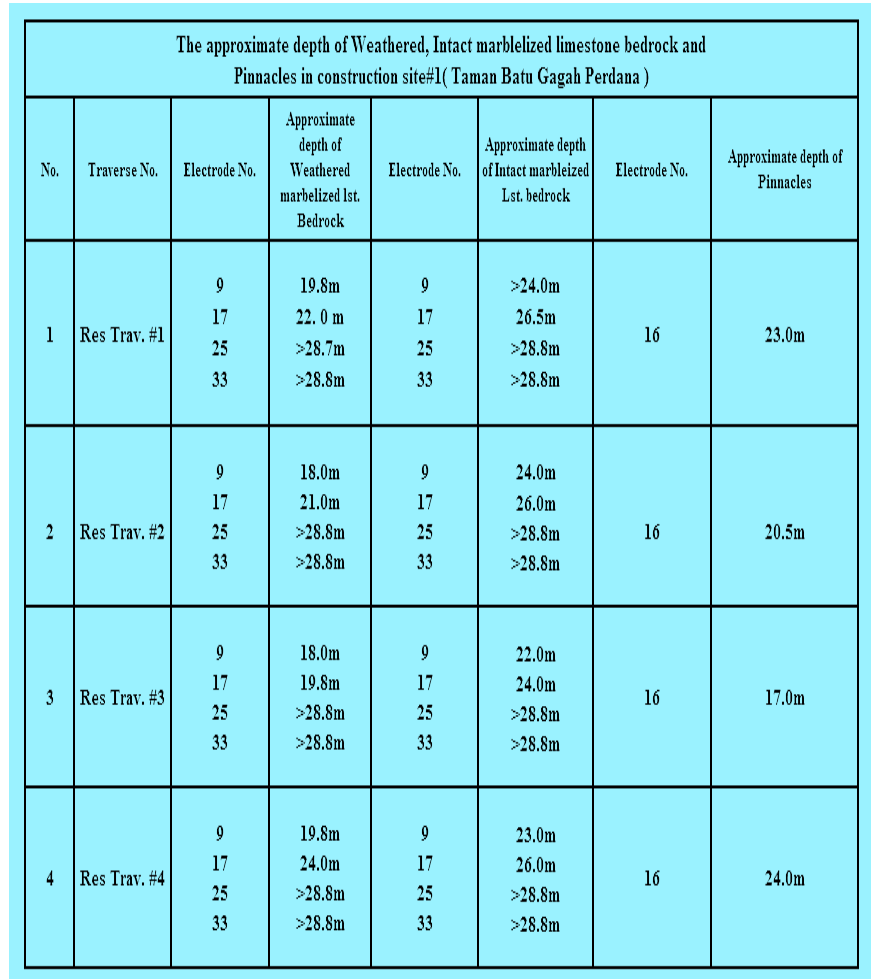

Table 10-A: Describe the approximate depth of weathered, intact marbleized limestone bedrock and pinnacles in construction site\#1(Taman Batu Gagah Perdana)

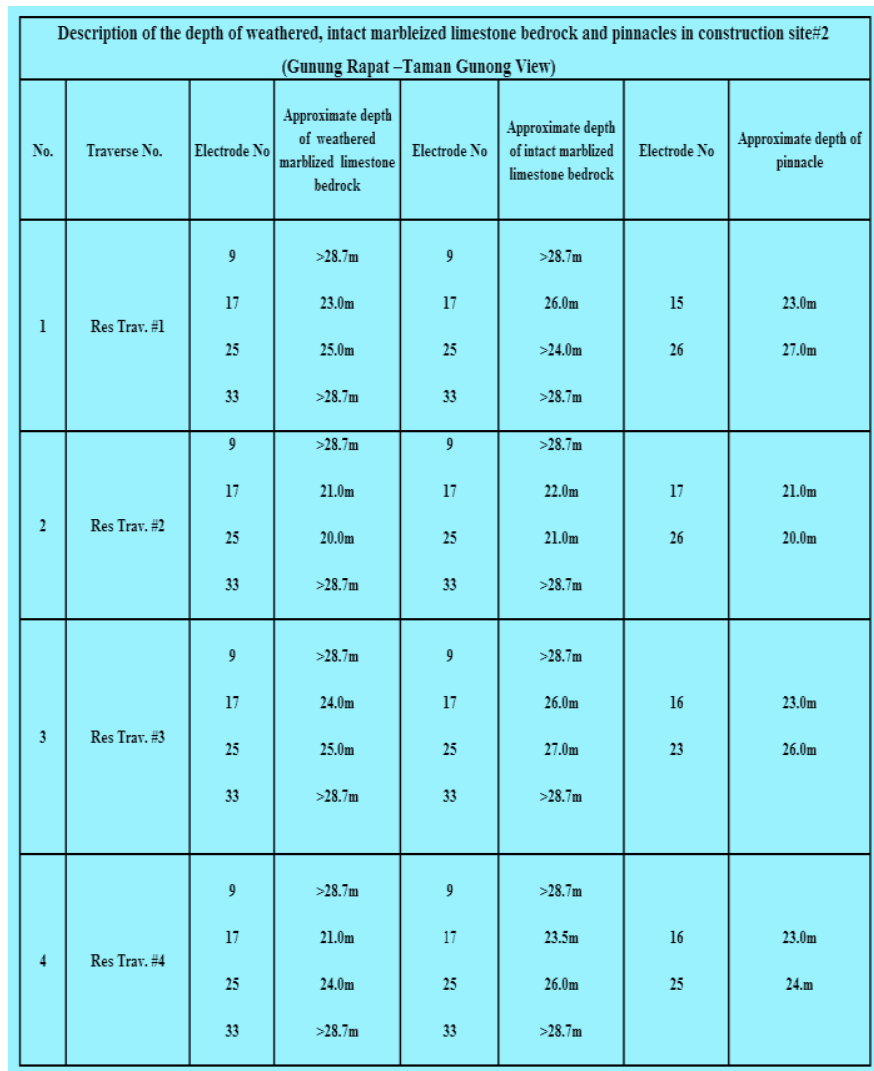

Table 10-B: Describe the approximate depth of weathered, intact marbleized limestone bedrock and pinnacles in construction site\#2(Gunung Rapat) 


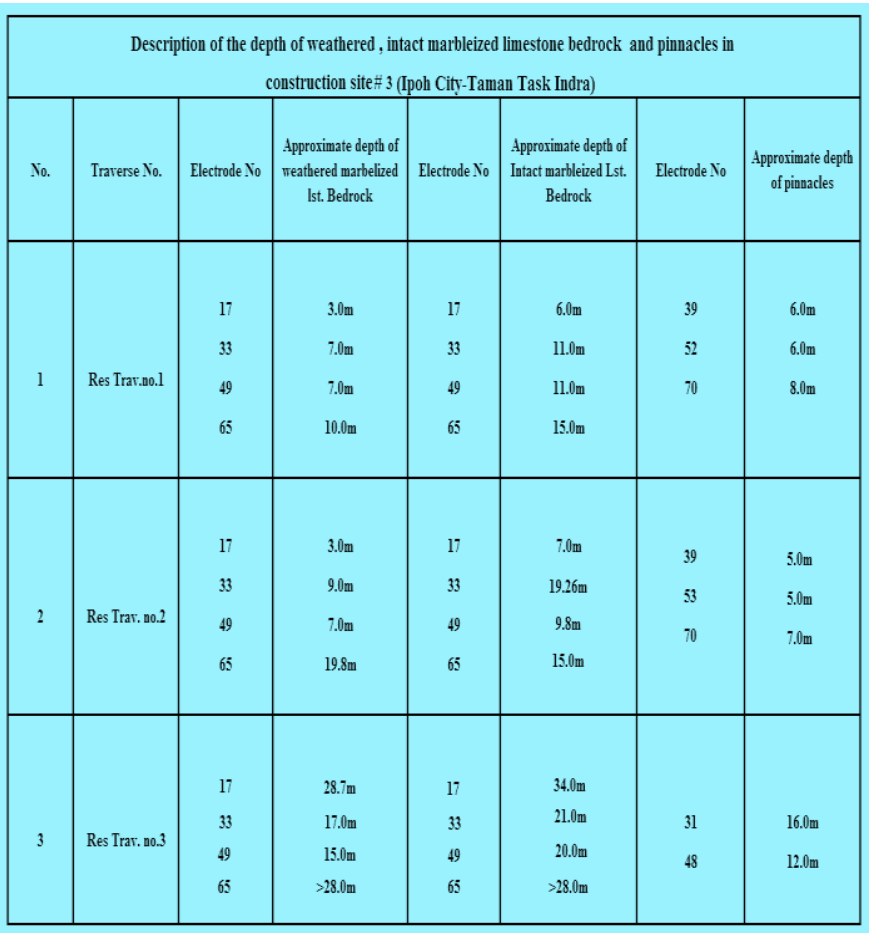

Table 10-C: Describe the depth of the approximate depth of weathered, intact marbleized limestone bedrock and pinnacles in construction site\#3(Ipoh City)

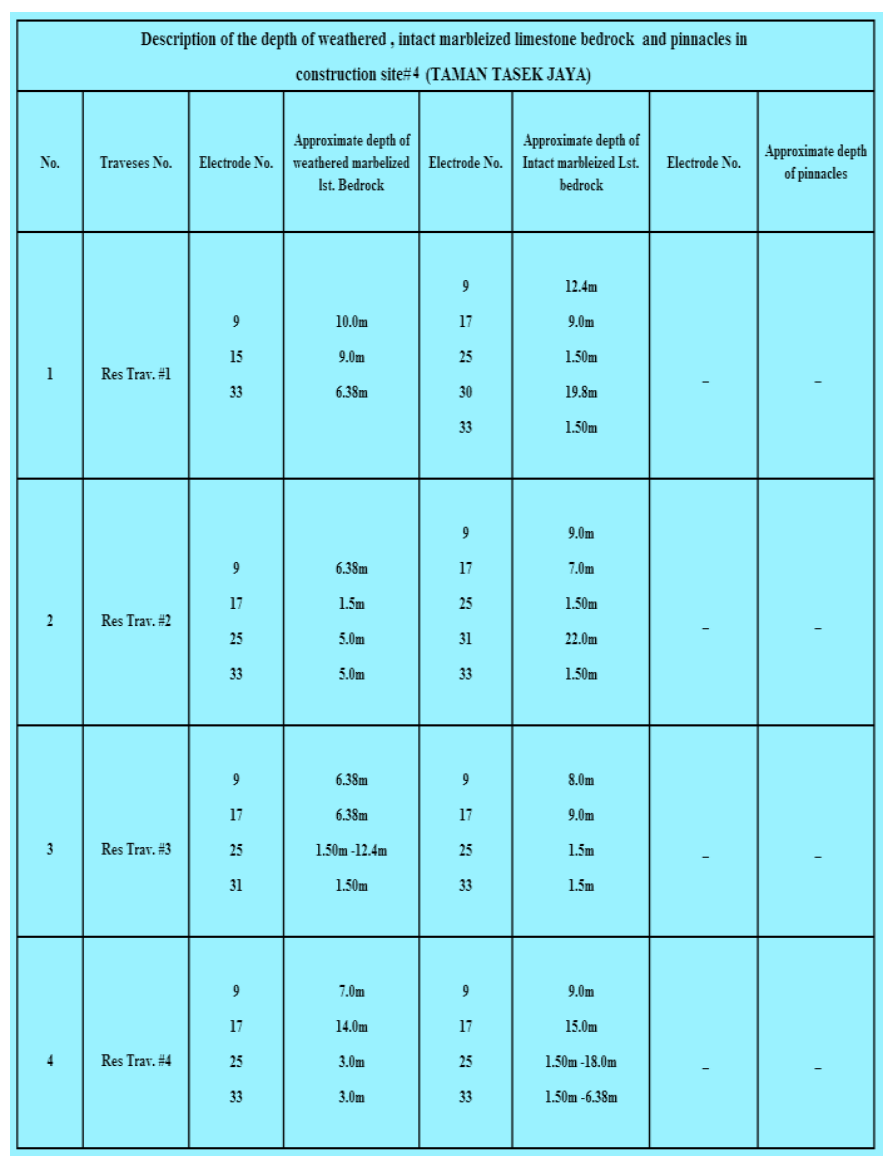

Table10-D: present the descriptions of the approximate depth of weathered, intact marbleized limestone bedrock and pinnacles in construction sites\#4

(Taman Task Jaya)

\begin{tabular}{|c|c|c|c|c|c|c|c|}
\hline \multicolumn{7}{|c|}{ The approximate depth of Weatherel, Intact marblelized limestone beetrock and } \\
Pinnacles in construction sitet5 (Taman Klebang Putra $)$
\end{tabular}

Table 10-E: Describe the approximate depth of weathered, intact marbleized limestone bedrock and pinnacles in construction site\#5 (Klebang Putra)

\section{MITIGATION THE GEOHAZARD OF CARBONATE KARST FEATURES IN CONSTRUCTION SITES BY APPLICATION OF ENGINEERING SUBSURFACE REMEDIATION TECHNIQUES}

\subsection{Engineering Surface and Subsurface Remediation Techniques}

The assessment and optimization in the operation of remedial systems over the last several decades has provided a substantial database of information regarding their performance and cost. With this information, assessments of system performance and recommendations used to gather, analyze for optimization and the approaches have been performing on many operations are applicable to existing remedial systems as aids in reducing costs and shortening remedial time-frames. This work addressed current approaches and tools for assessing the performance and optimizing the design of existing and planned remedial systems. Technology groups addressed include above ground treatment systems and natural attenuation.

Remediation methods, categorized as chemical or physical, are covers to provide a comprehensive overview for remediation. It has intended to provide in-depth detail for anyone technique, to serve as initial guidance for remedy selection alternatives and to act as a catalyst in optionspecific. Geological and geotechnical surface and subsurface site characterization, modeling, monitoring, and remediation 
are important to hazard mitigation, economical safe, responsible development, operation of remediation and maintenance works. The most significant geotechnical challenges in these tasks are monitoring of fluids paths and velocities that seepage from surface and travel through the sinkholes and subsurface fractures. The types of foundation for any construction project over carbonate karst regions depend upon the expected foundation loading and the degree of maturity of the karst features. The greatest danger to the site is when foundations have positioned over sinkholes. In this case, two additional factors need to be taking into consideration; the overloading aspect and water seepage into sinkholes through the soil cover.

If the level of karst ground condition under construction site has identified and classified, the most economical point of view in developing this site to mitigate or minimize the risk of structures that are founding over the area involves determining the safest direction in changing the plan's location. If possible, the most important sections and those with great size construction structures have to be position in the safest region, while the problem areas can allocate for non-critical facilities, such as grass fields, parking lots, golf courses, and roadways, etc. Controlling the surface and subsurface water drainages must put in the plans when the work is commencing at these respective sites.

Several engineering subsurface remediation techniques are available to repair any construction site threatened by cover-collapse sinkholes, to transfer the load of the future building structure to recognizable bedrock. The best remediation technique of the sinkhole repair varies depending on the size and stability of the hole. For the smaller hole with compact ground at its lowest level, replacing soil and repairing ground cover will be enough. Sinkhole with very large holes with unstable sides or low points where can excavate it to the bedrock and can be repaired by layering varying sizes of stone topped by gravel and soil.

The sinkhole is a depression in the ground caused when groundwater erodes subsurface rock allowing the clay above it to sink. These holes range varies in size manly from about $0.9 \mathrm{~m}$ to more than $23.0 \mathrm{~m}$ wide and its depth ranges manly from 1.0 meters to more than 12.0 meters. Begin the process of sinkhole repair by testing the width and depth of the sinkhole through the geophysical section. If the hole is very large, the best method of professional sinkhole remediate if can excavate to bedrock and re-fill or reinforce as needed.

At a less imperative way rapidity can be used is filling the sinkhole by apply of reverse graded filter technique. The purpose of the graded filter is to allow water to seep into the ground while the soil has held back. In the case of great sinkholes, the graded filter construction is essentially the same, but the final layers are fine gravel, coarse sand, and fine sand. The uppermost layer is bentonite clay that blocks water seepage.

A variety of techniques for surface and subsurface remediation have been gathered and summarized. The study has intended to provide an overview of remediation methods currently utilized at various hazardous construction sites. Specific examples of the techniques and methods available that applied when possible and the situations for each technique have provided and have given more information in detail.

\subsection{Mitigate the risk of problem areas in construction site \#1 (Batu Gagah -Taman Batu Gagah Perdana)}

Three solution methods that most frequently has used in the plans to mitigate or minimize the risk of the problematic areas in construction site\#1 (Batu Gagah -Taman Batu Gagah Perdana).

\subsubsection{First Solution Method to Minimize the Risk of the Problematic Areas by Improving the Ground Surface}

Preparing the land for future development projects consist of many stages. The first stage is cleaning the land from the plants and bushes. The second stage, the upper most or a final layer completed with Bentonite clay about 4.0/5.0 inches to prevent water seepage from occurring. The third stage is the ground surface covers with soil about 6.0/7.0 inches. The fourth stage surface soil need to improvement, through improving the ground surface by rolling and compaction process to increase the stiffness and performance capacity of the soils through decreasing the permeability in this construction site. Improving the ground surface by rolling and compaction process to increase the stiffness in construction site\#1 is one of engineering surface remediation technique presenting in figure 36.

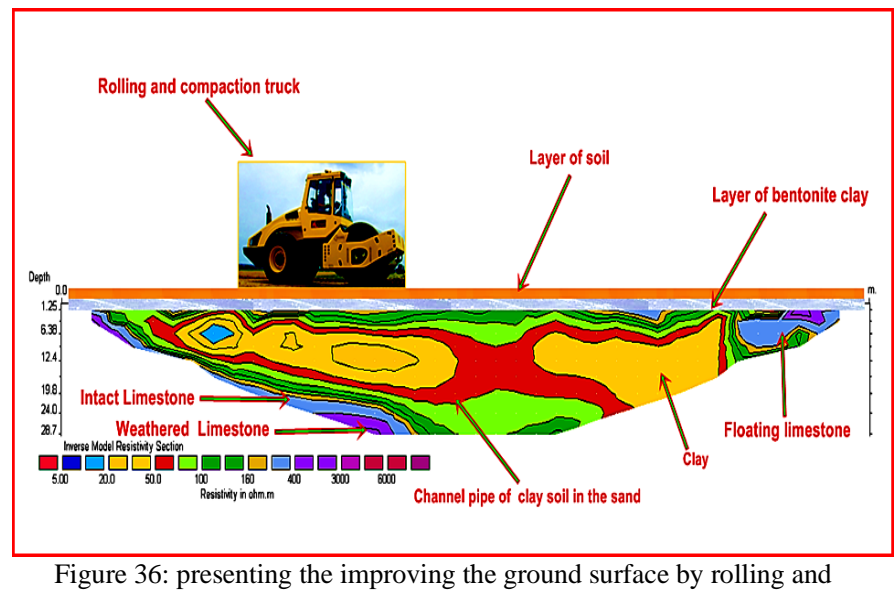
compaction process to increase the stiffness in construction site\#1

\subsubsection{Second solution method to minimize the risk of the problematic areas by using of chemical compaction grouting process}

This method includes filling the channel pipe by using of chemical compaction grouting process with a geopolymer solution form (urethane). It can be utilizing to fill the fractures, small voids and the cavities in the subsurface layers. Chemical grouting is well suited for channels, and for stabilizing the soil around the channel in mitigating the 
settlement of overlying structures within the influence of the channel's configuration.

Chemical solution forms were injecting into drilled holes along the flow paths of the channel, sealing and preventing the flow of any rainwater through them in the future. Filling the channel pipe by using the chemical compaction grouting process with geopolymer solution form (urethane) in construction site\#1 is one of the engineering subsurface remediation techniques presenting in figure 37.

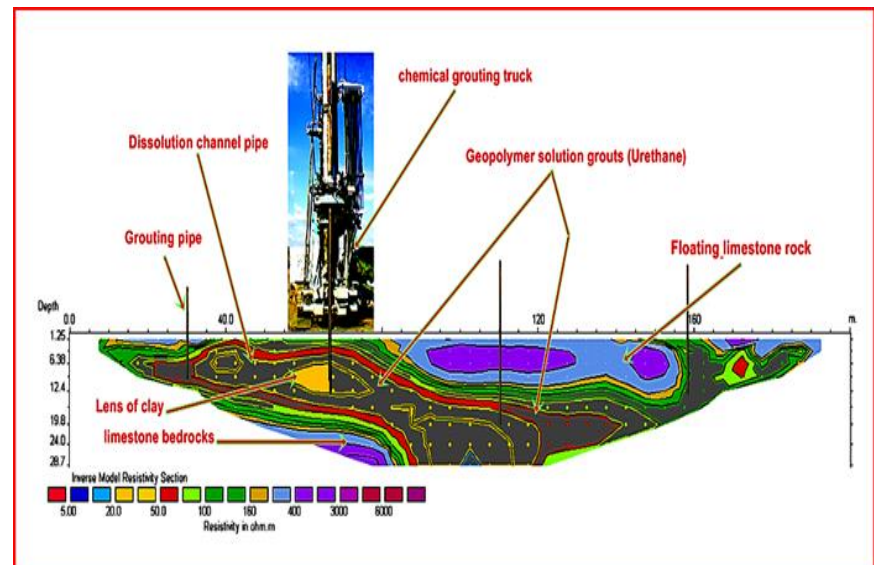

Figure 37: Filling the channel pipe by using of chemical compaction grouting process with geo-polymer solution form (urethane) in construction site\#1

\subsubsection{Third Solution Method to Minimize the Risk of the Problematic Areas By Driven of Skin Friction Piles into Softer Materials}

Long skin friction piles can drive down through the softer material to specified depth in this construction site. In this type of pile, the load-bearing resistance derived on pile mainly from skin /friction resistance along the side of the pile shaft, so that the friction of the soil against the sides of the pile is enough to resist any downward movement.

High capacity of friction piles develops a considerable carrying load which it's a function of vertical support from skin friction is developed between the surface of the buried pile shaft area in addition, the contact with the surrounding soil. That depends on the good quality of friction piles with moderately length.

In addition, because the area with soil has less cohesion or softer materials (silty, clay and sandy soils) with medium to low density, the friction piles here are frequently used to increase the density.

When no layer of the bedrock is coming across at a logical depth of this construction site, the end bearing piles become uneconomical and very long for this type of subsoil material condition. Skin Friction Piles that are driven into softening materials (silty, clayey and sandy soils), without encountering intact layer bedrock (with depth $>30 \mathrm{~m}$ ) in construction site\#1 presenting in figure 38 .

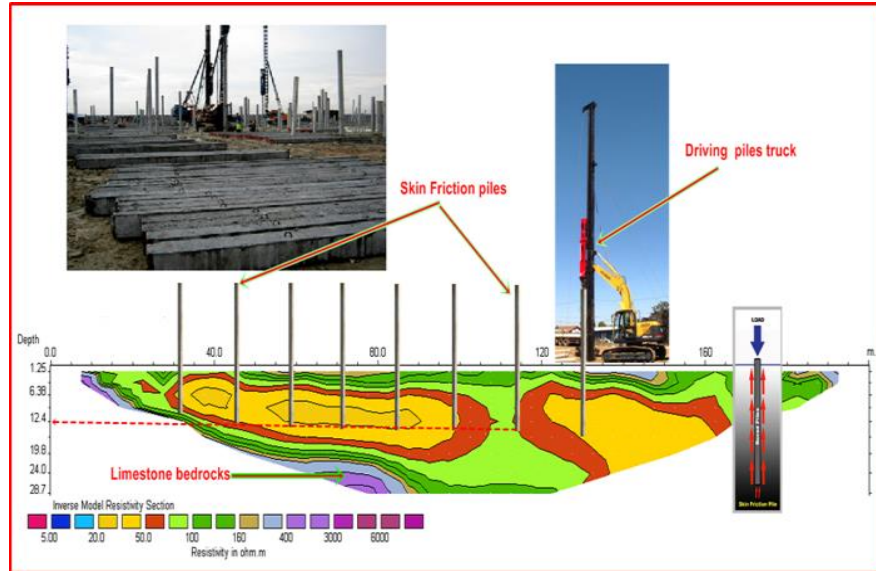

Figure 38: Presenting the Skin Friction Piles driven into soften materials (silty, clayey and sandy soils) without encountering intact layer bedrock (with depth $>30 \mathrm{~m}$ ) in construction site\#

15.3 mitigate the risk of problematic areas in construction site \#2(Gunung Rapat -Taman Gunong view)

Three solution methods are the most frequently used in the plan to mitigate or minimize the risk of problem areas in construction site\# 2(Gunung Rapat -Taman Gunung View):

\subsubsection{First Solution Method Is To Minimize the Risk of the Problematic Areas by Remediation of Small Sinkholes Using a Bentonite Drilling Mud and the Rock Cutting}

Preparing the land for future construction project consists of many stages. The first stage is cleaning the land from the plants and bushes. The second stage, small sinkholes remediation by using Bentonite drilling mud and the rock cutting from the drilling operation as one of the steps of environmental management in oil and gas exploration, after the water and other liquids are removed to refill the small sinkholes in this construction site would be the ideal solution.

To fill these small sinkholes, first excavate the holes, then filling it with bentonite drilling mud and the rock cutting. After that, if possible to spray the filling sinkholes with a geopolymer chemical solution to fill the gaps between the rocks fragments. In the third stage, the uppermost of the sinkhole area completed with bentonite clay about 4.0/5.0 inches to prevent water seepage from occurring.

Later, the final layer of the ground surface should cover with soil about 6.0/7.0 inches. Surface soil needs improvement in this construction site by rolling and compaction processes to increase the stiffness by decreasing the permeability in this construction site.

Small sinkholes remediation by using Bentonite drilling mud and the rock gutting from the drilling operation of (oil and gas industry) is one of the engineering subsurface remediation techniques in construction site\#2 presenting in figure 39. 


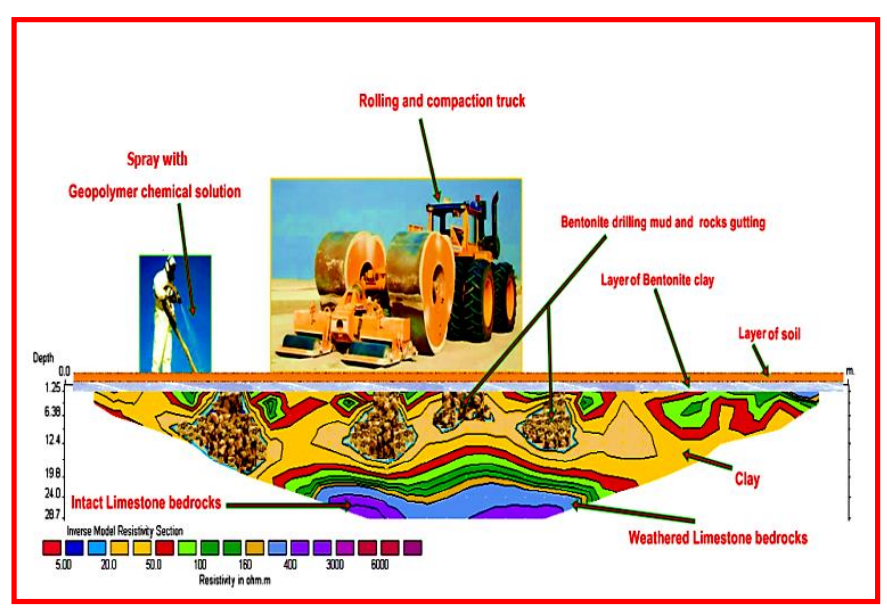

Figure39: Small sinkholes remediation by using of Bentonite drilling mud and the rock gutting from the drilling operation of (oil and gas industry) in construction site\#2

\subsubsection{Second Solution Method Is To Minimize the Risk of the Problematic Areas by Using of Deep Grouting Chemical Solution}

Deep grouting by using of geopolymer chemical solution grouts (urethane) is a form of penetration grouting. A cost-effective professional process uses chemical solution forms to fill the small voids and fissures in the soil. The best type of soils suited for this technique are granular soils, with significant fine sand content, that strengthen the ground and prevent excessive movement.

Chemical grout has injected through the joints and a gap in the surrounding soil, where it solidifies with the soil making it appears relatively impermeable and hard. The deep grouting by injection of chemical solution is one of the engineering subsurface remediation techniques in construction site\#2 presented in Figure 40.

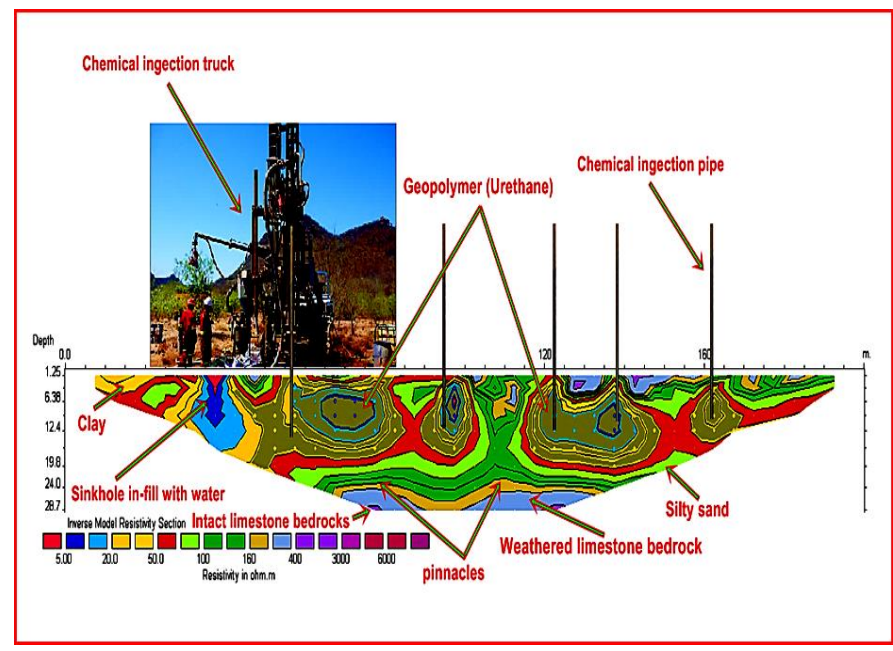

Figure 40: presenting the deep grouting by injection of chemical solution in construction site\#2

\subsubsection{Third Solution Method Is To Minimize the Risk of the Problematic Areas by Using of Raft Foundation}

Raft foundation, Mat foundation (also, it's well known as Floating Foundation) required and necessary where soils have low bearing capacity and have to hold up heavy structural loads on swampy land, soft clay, and unconsolidated soil material. Raft foundation is necessary where an area that subsidence may occur from different reasons such as due to the presence of soil cover collapse sinkhole.

The changes in the groundwater level especially in this area with extended soil. Raft foundation is the economical solution in this site where the deep pile foundations are not possible and not economical. The type of Raft foundations or floating foundations that were convenient in construction site\#2 is one of engineering subsurface remediation technique presenting in figure 41 .

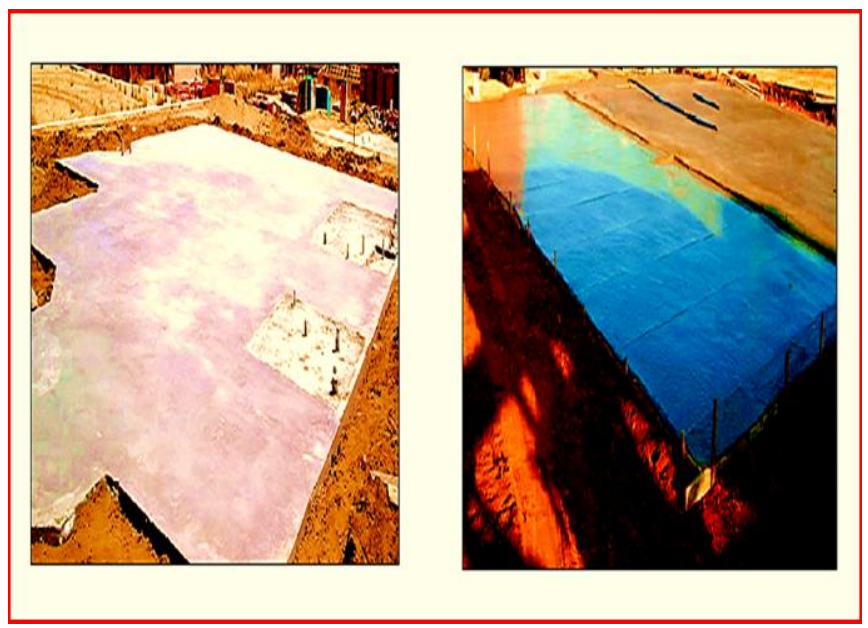

Figure41: Presenting the Raft, Mat foundations or floating foundations that were convenient in construction site\#2

Raft foundation, Mat foundations or floating foundation is required and necessary, because in this area the thickness of the soil is very high and contains unconsolidated material with low bearing capacity. Raft foundation is necessary where an area that subsidence may occur from different reasons such as due to the change in the climate, especially in the area of mining activity, leads to the alteration in groundwater level.

Raft foundation is the economical solution in this site when the deep piles' foundations need to use with length more than $15.0 \mathrm{~m}$ or 20.0 for different structures projects and become impossible and not economical.

\subsection{Mitigate the risk of problematic areas in construction site \#3 (Taman Tasek Indra- Ipoh city)}

Three solution methods that are the most frequently used in the plan to minimize the risk of problematic areas in construction site\#3 (Taman Tasek Indra- Ipoh city) demonstrate in following: 
15.4.1 The First Solution Method to Minimize the Risk of the Problematic Areas, In Construction Site\#3 by Using of Reverse Graded Filter Technique in Sinkholes Remediation

Clearing the ground surface from all plants and vegetation and repairing it for the building projects. In addition, sinkholes remediation is by using of reverse graded filter technique. At the first stage, the hole must be excavated, the second stage, then the bottom of the hole shall be plugged with concrete or larger rocks, after that, filling the hole by coarse gravel, then fine gravel, coarse sand and finally fine sand.

After that, fill the empty spaces or the gaps in the filling materials by spraying with a geopolymer solution. Moreover, can using Bentonite drilling mud and the rock gutting from the drilling operation after water and other liquids are removed is to re-fill the depression and the sinkholes in this construction site.

The most of upper area with sinkholes can cover with two layers of graded crushed stone. The final layer covers the ground surface is the soil with thickness about 6.0/7.0 inches, followed by soil surface improvement via rolling and compaction processes to increase the stiffness of the soil. Sinkholes remediation by using the reverse graded filter technique in construction site \# 3 is one of the engineering subsurface remediation techniques presented in figure 42 .

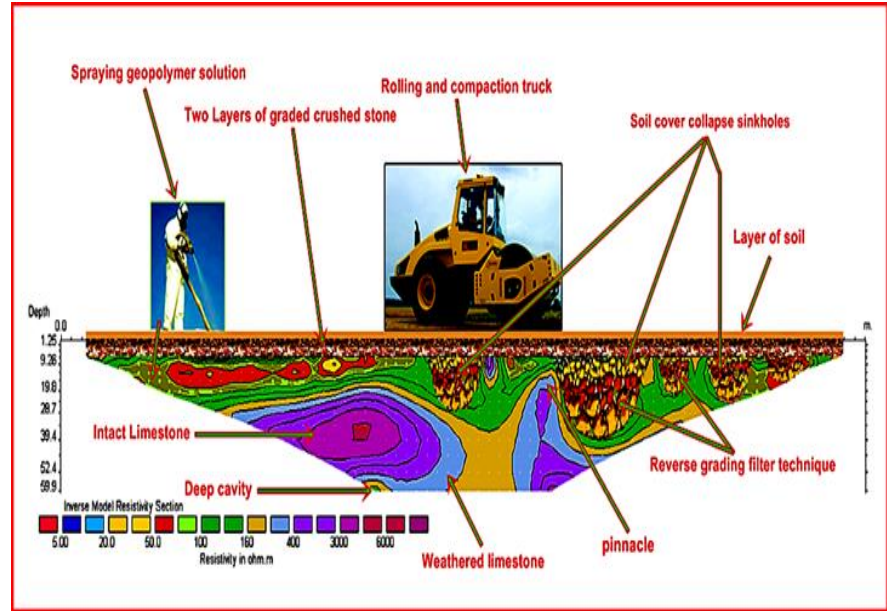

Figure 42: presenting the sinkholes remediation by using of the reverse graded filter technique in construction site \# 3

\subsubsection{The Third Solution Method to Minimize the Risk of the Problem Areas in Construction Site\#3 by Placing of Shallow Spread Footings at Regular Intervals}

The placing of shallow spread concrete footings as foundations at regular intervals, to transfer the loads from the building down to the footings. In this location, a relatively stiff layer (bedrock) exists with shallow depth about (3.0) m.

In this case, it is usually more economical to use concrete footings as foundation support for the building. The footing effectively spreads the weight from the building column over an area, so that the contact pressure is lower than what the ground can support. Typical spread footings under construction in construction site\#3 presenting in figure 43.

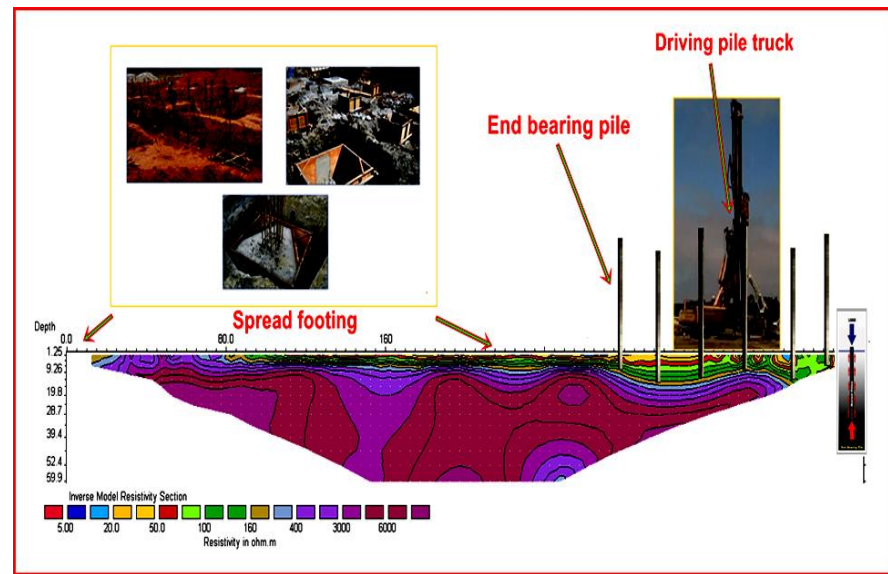

Figure 43: End Bearing Piles that driven across Limestone layer (bedrock) and typical spread footings under Construction in construction site\#3

\subsubsection{Fourth Solution Method to Minimize the Risk of the Problematic Areas by Using of Deep Grouting Chemical Solution}

Deep grouting by using of geopolymer chemical solution grouts (urethane) is a form of penetration grouting. It is a cost-effective professional process that uses chemical solution forms, can be utilized to fill the small voids and fissures and the cavities in the subsurface layer and in rock head pinnacles.

The soils best suited for this technique are granular soils, with significant fine sand content, that strengthen the ground and prevent excessive movement. In addition, the chemical solution grout has injected through the joints and gaps in the surrounding soil, where it solidifies with the soil to make it appear relatively impermeable and hard. Deep grouting by injection of chemical solution in construction site\#3 is one of the engineering subsurface remediation techniques that presented in figure 44 .

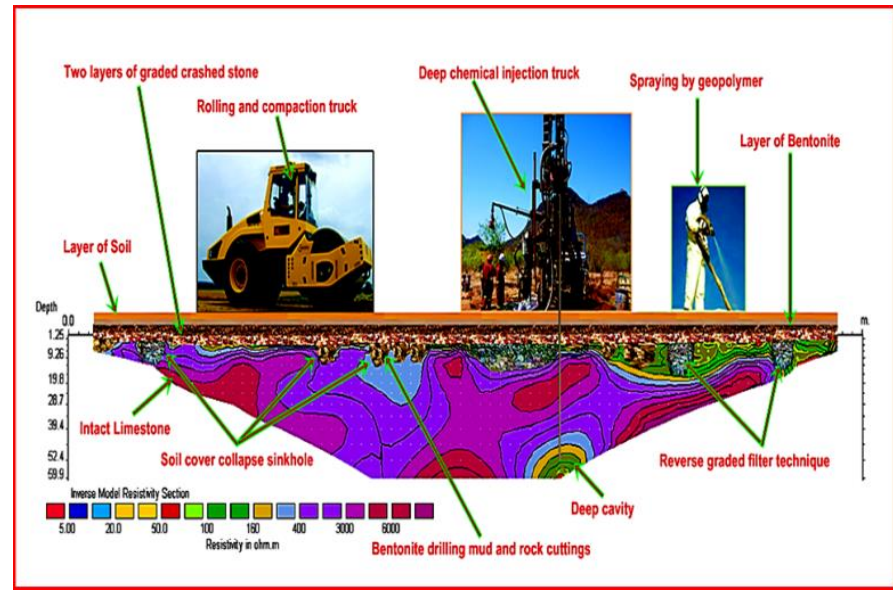

Figure 44: The deep grouting by injection of chemical solution in construction site\#3 


\subsection{Mitigates the risk of problematic areas in construction site \#4 (Taman Tasek Jaya)}

Four solution methods that are the most frequently used in the plan to mitigate the risk of problematic areas in construction site\#4 (Taman Tasek Jaya) demonstrate in following:

\subsubsection{The First Solution Method to Minimize the Risk of Problematic Areas by Using of Grouting Technique with Geo-polymer Solution Forms}

Grouting via injection of a chemical solution with Geo-polymer forms can be utilizing to fill the fractures, small voids, and cavities in subsurface layers. When the chemical solutions have injected into the cracks will seal the fractures and joints. Geo-polymer grout injected through the drilled holes along these flow paths of the fracture channels, sealing and preventing the flow of any rainwater through them in the future. The deep grouting by injection of chemical solution forms in construction site\#4 is one of the engineering subsurface remediation techniques presenting in figure 45 .

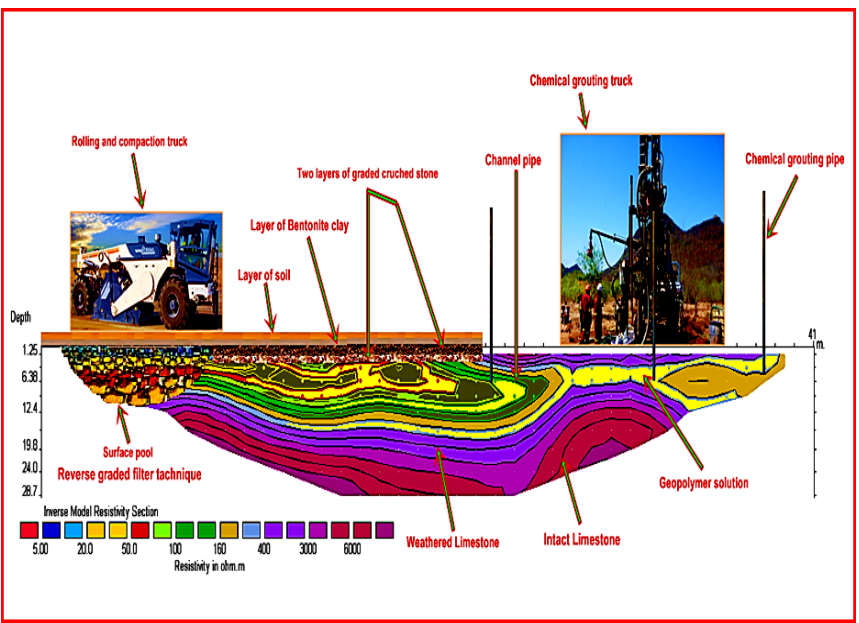

Figure 45: Deep grouting by injection of chemical solution forms in construction site \# 4

\subsubsection{The Second Solution Method to Minimize the Risk of Problematic Areas by Using Of Rock Fissures Grouting Technique}

Rock fissure grouting technique is useful when a hole drilled through the fissures and joints of a rock mass to allow grout to inject. There is only one grouting mechanism for rock fissure grouting. The grout injected under pressure through the grout hole drilled into the rock mass that needs to be treated. This type of grouting is used to the filling of the fractures and the fissures in rocks to reduce permeability, strengthen or stabilize the rocks, or both. The grout is constructing by the drilling and grouting of closely spaced drill holes oriented to optimize the intersection of rock joints. The most common application is to Pre-treatment of permeable rock masses. Grouting of a water-bearing zone is to minimize the quantity of water to handle within a shaft excavation. Rock fissure grouting technique in Progress to fill the open joints and fissures in construction site \# 4 is one of the engineering subsurface remediation techniques presenting in figure 46 .

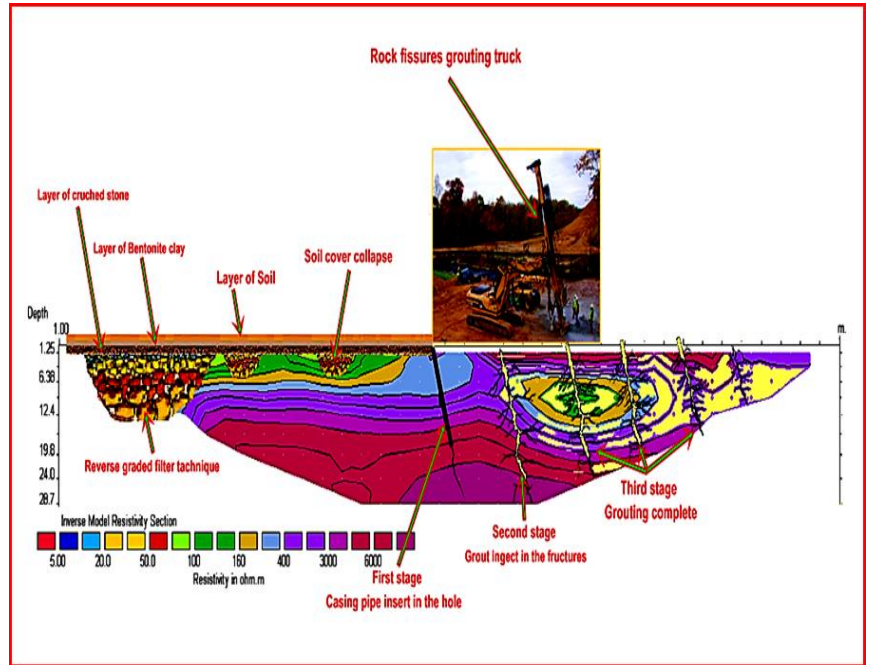

Figure 46: Rock fissures grouting technique in progress to fill the open joints and fissures in construction site\#4

\subsubsection{The Third Solution Method to Minimize the Risk of Problematic Areas by Placing Of Shallow Spread Footing or Pad Footing Foundations}

Placing of shallow Spread Footing or Pad Footing foundations at regular intervals to transfers the load from the building down to the footings. In this location, a relatively stiff layer (bedrock) exists with shallows depth about (2.50) $\mathrm{m}$. In this case, it is usually more economical to use concrete footings as foundation support for the building.

The footing effectively has spread the weight from the building column or pillar over a larger area by enlarged pad bases, so that the contact pressure is lower than what the ground can support. The shallow Spread Footing or Pad Footing foundations in construction site \#4 presenting in figure 47.

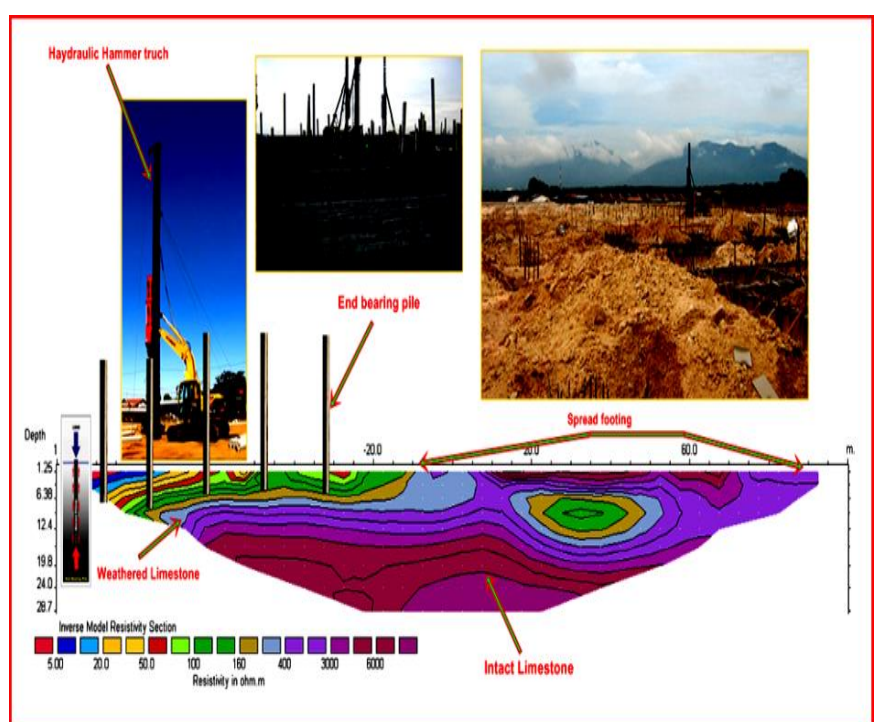

Figure 47: End Bearing Piles that driven across Limestone bedrock and spread footings or pad footings foundations under construction in construction site\#4 
15.5 Mitigate the risk of problematic areas in construction site \# 5 (North Ipoh -Taman Klebang putra)

Four solutions methods that are the most frequently used in the plans in order to mitigate or minimize the risk of the problematic areas in construction site \# 5 (Taman Klebang Putra) demonstrate in following:

\subsubsection{First Solution Method to Minimize the Risk of the Problematic Areas, Through Sinkholes Remediation by Using Reverse Graded Filter Technique}

Mostly, the sinkhole remediation achieved by utilizing the reverse graded filter technique. To fill this huge sinkhole, the hole must be excavated, and its throat plugged by concrete block, sealed with a thick grout of cement.

Then seal the hole at the bottom with larger boulders or rocks, followed with a cobble, then gravel or bentonite mixed with rock fragments. After that by sand and finally, the top must be cover with (8-12) inches of soil. The placement of larger materials directly on the bedrock at the bottom of the sinkhole is done in order to, provide support and prevent another collapse, while the smaller materials stops water from moving the soil down into the voids, and then to the bedrock.

The sinkhole remediation completed by utilizing the reverse graded filter technique in construction site \# 5 presenting in figure 48 .

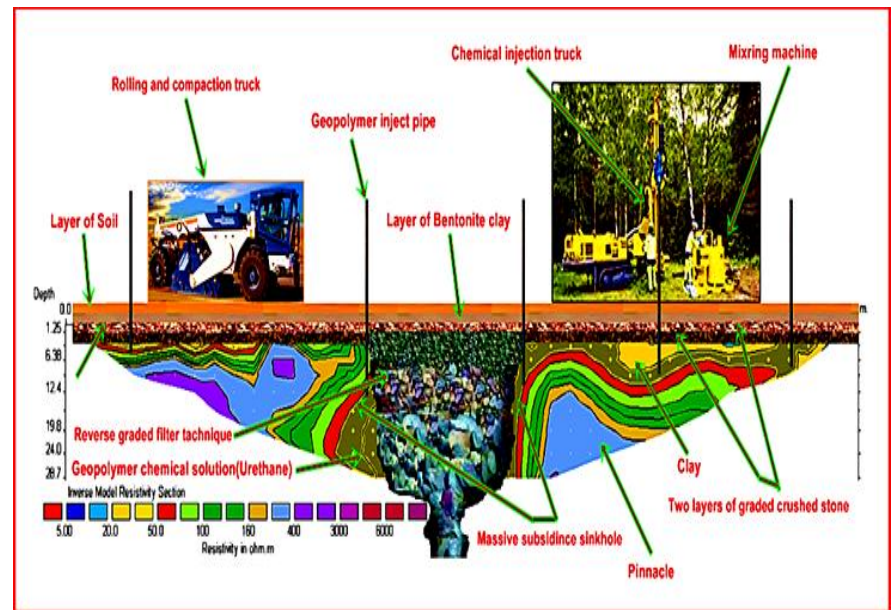

Figure 48: Sinkhole remediation completed by utilizing the reverse graded filter technique in construction site \# 5

\subsubsection{Second Solution Method to Minimize the Risk of the Problematic Areas, By Using Concrete Bridge Beam}

The remediation of the sinkhole by using concrete bridge beams in order to transfer the load of the constructions to the both sides of the massive or grate sinkhole. The applying of this method has consisted of four main stages.

The first stage is driving along bearing pile or column down to a point that is resting on sound rock strata. This column or a pile will transfer the loaded weight of the bridge to the ground. The second stage is the setting of a concrete support block or the abutment that is the connection between the end of the bridge and the earth, which provide the support to the two end parts of the bridge. The third stage is, filling the hole with larger boulders or rocks at the bottom, followed with cobbles, then by gravels.

If the sinkhole is very dangerous to designed foundations, it must be packing with concrete. The fourth stage is the setting of the superstructure of the concrete bridge beam that is a horizontal platform spans the space between two abutments or concrete support block over the first and second elements. The sinkhole remediation by use of concrete bridge beam in construction site \# 5 presenting in Figure 49.

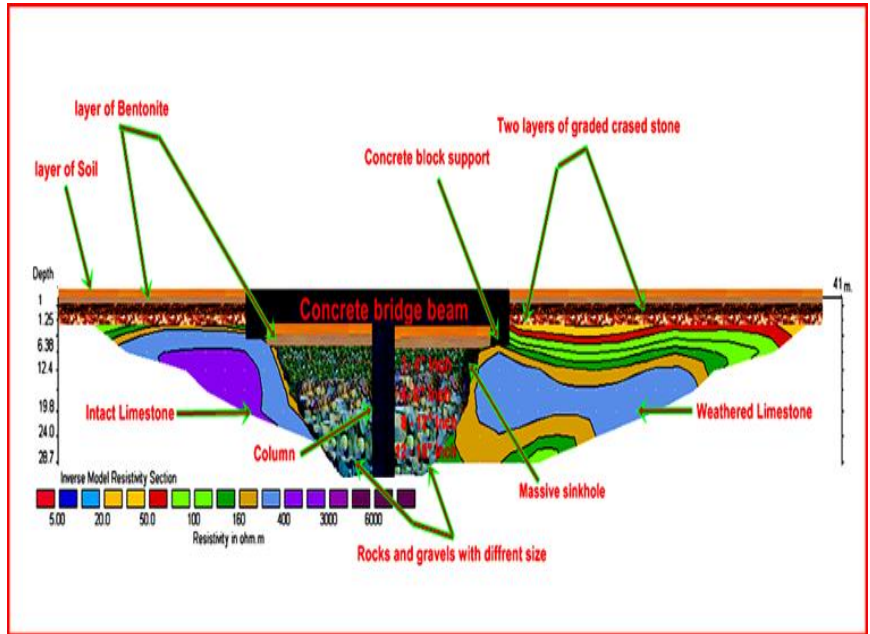

Figure 49: present the sinkhole remediation by using of concrete bridge beam in construction site\#5

\subsubsection{Third Solution Method to Minimize the Risk of the Problematic Areas, By Using Bentonite / Cement Grouting Compaction Technique}

Soil stabilization by using the Bentonite / Cement grouting compaction technique can be utilizing to fill the small voids and fissures in the soil. This technique is best appropriate for the granular silty, sandy and clayey soil with significant fine sand content that strengthens the ground and prevent excessive movement in the future.

- First, include injected the grouts into the drilled holes.

- Second, the grouts are compacted into the joints and gaps in the surrounding soil, where it solidifies with the soil it will make it is appear relatively impermeable and hard

The soil stabilization by using of Bentonite / Cement grouting technique in construction site \# 5 is one of engineering subsurface remediation technique as presented in figure 50 . 


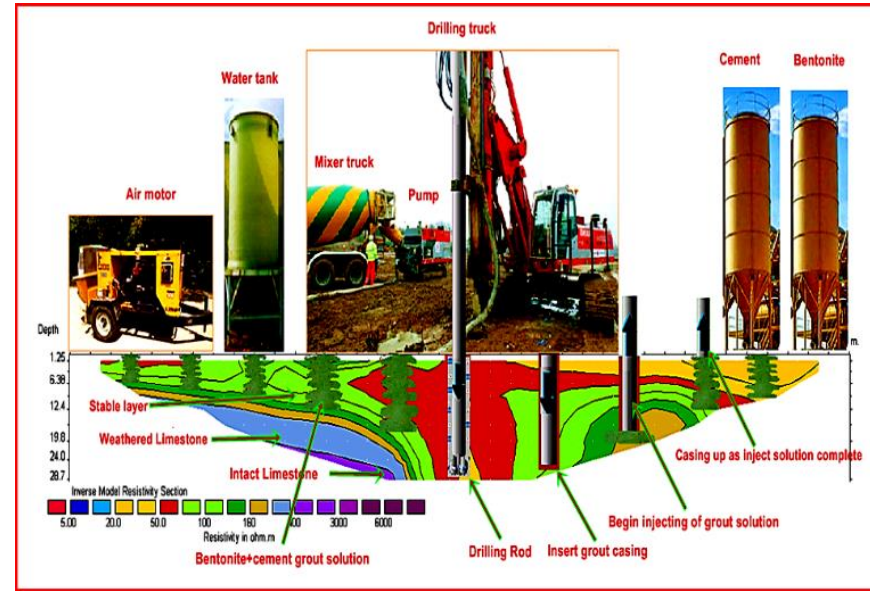

Figure 50: The soil stabilization by using of Bentonite / Cement grouting technique in construction site \#5

\subsubsection{Fourth Solution Method to Minimize the Risk of the Problematic Areas, By Placing the all Project to the Safest Region}

If it is possible, relocation the most important part with great size and type of construction structures to be placed in the safest region, may prove to be more costeffective in certain cases. While the problematic areas can allocate for non-critical facilities, such as grass field, play area.

\section{The geotechnical table for engineering classification of karstic ground conditions}

The first engineering classification of karst ground conditions present by A. C. Waltham and P. G. Fookes, (2005) which describe simplified guidelines to the potential variation in landforms and the characteristics of the morphological features and ground cavities that possibly come upon in civil engineering works on karst terrains. This classification divides the Karst terrains in planet earth into five classes. The five classes illustrate the karst terrains in terms of the difficulty and complexity that come across the foundation engineers. In these classifications, the carbonate karst regions in Malaysia classified as extremely karst terrains.

Through the study of karst regions found that the strength of karstification is different from one site to another in the same region. A geo-technical table for engineering classification of karst ground conditions that presented by Yassin, R., R. \&Almashaiky, D. (2005). This table classifies the karst terrains in the desert and semi-desert regions to five classes after discovering complex and extreme subsurface karst features through applying of the geotechnical survey. After that, this table developed to classify the karst in semiwet and wet tropical regions presented by Yassin, R., R. \& Haji, Taib, S. (2012) which describe the subsurface features that come upon in engineering works on karst terrains, after applying of the geotechnical survey.

This table applies in Malaysia peninsular and includes five (5) classes, start from Youthful karst (KaI) and ending with extremely complex karst $(\mathrm{KaV})$ as shown in the following:

\section{Class KaI: Youthful karst:}

Found only Infrequent sinkholes, with unvarying and even rockhead pinnacle, certain of minor and isolated remnant features, rare cavities, caves are rare and small, with several sizes less than $3.0 \mathrm{~m}$ across.

\section{Class KaII: Adult karst:}

Small dripping out sinkholes, small open stream sinks, small features, and cracks are widespread within few meters nearest to the surface, small cavities, various types of small caves with size greater than $5.0 \mathrm{~m}$ across.

\section{Class KaIII: Mature Karst:}

Numerous types of medium dissolution and subsidence sinkholes, a wide distribution of medium collapse and buried sinkholes, pinnacles release with tall $5.0-20 \mathrm{~m}$ across, loose pillars, medium-range of dissolution depresses and fractures, Medium cavities, Caves with several sizes, greater than $15.0 \mathrm{~m}$ across.

\section{Class KaIV: Complex Karst:}

Numerous types of large dissolution sinkholes, various types of large subsidence or collapse sinkholes, numerous types of large spread and buried sinkholes, large of relief rockhead Pinnacles, wide-range of dissolution depresses and major fractures, large cavities, multilevel caves, with several sizes greater than $50.0 \mathrm{~m}$ across

\section{Class KaV: Extremely Complex:}

Extra-large sinkholes of all types, extra-large buried sinkholes in-fill with compact sediments; greater of relief rockhead pinnacles, deep soil fissures, complex dissolution cavities, numerous type of complex cave systems with chambers and galleries, caves with size greater than $100.0 \mathrm{~m}$ across.

The geotechnical engineering classification of karst ground conditions in tropics and semi- tropics regions with cover karst environments present in table 17.

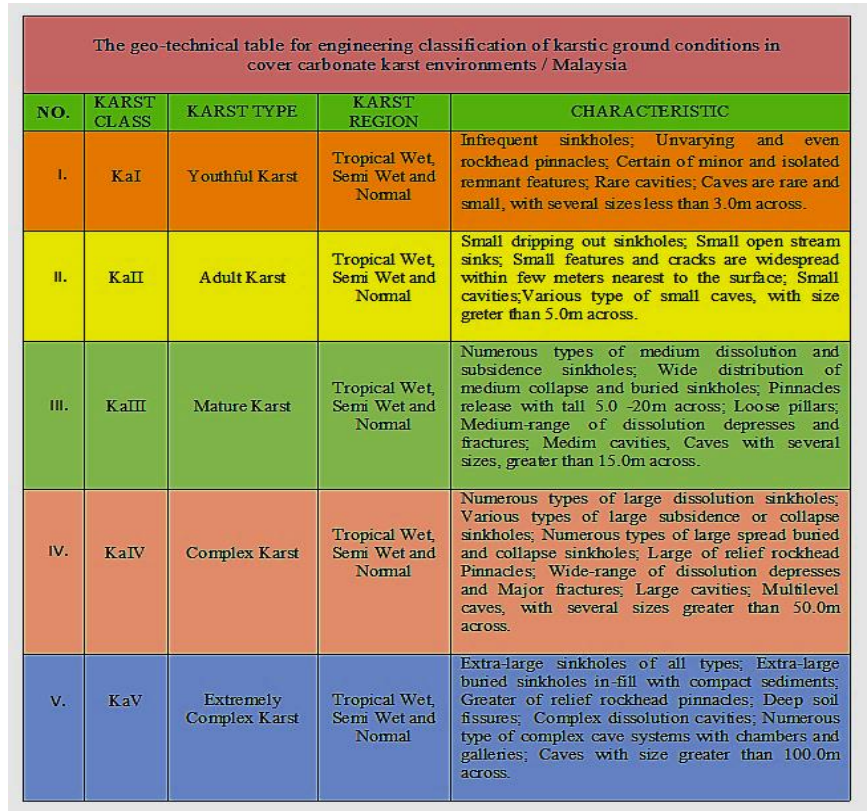

Table 17: The geo-technical table for engineering classification of karst ground conditions in cover Carbonate karst environments 


\section{RESULTS AND DISCUSSION}

1. The combination of geological, geophysical, aerial photographs, satellite image techniques were conducted at several construction sites in Perak state, peninsular Malaysia coupled with engineering subsurface remediation techniques in order to mitigate the geohazard of the subsurface geological carbonate karst features, including sinkholes, voids or cavities, and channel pipes. Furthermore, the geohazard of the subsurface geological structures such as solution-widened joints, intensely fractured zones and faults.

2. The interpretation of aerial photographic and satellite image techniques observed clearly that the orientation of lineaments (fractures and fault systems) from the Main series and Kledang series was cutting the marbleized limestone of Kinta valley and the hills above it. These give a consideration that there is a significant relationship between the geologic features and the origin of the karst features and the possibility of its development in the study area. In addition, the interpretation showed that the drainage in the study area is rather straight and angular and the stream courses have controlled by the direction of lineaments (fractures and fault systems) in the marbleized limestone bedrock.

3. Through the direct ground inspections in these five construction sites understudies, various types of sinkholes were founds distributed surrounding these sites. These sinkholes have not observed in the satellite images, because it contained modest evidence in the study area concerning the presence of sinkholes. This might be due to various factors such as the minuscule size of the sinkholes or their depth is too small to be detecting in the satellite images. On the other hand, concentrated plants might cover it. Alternatively, its formation and development occurred after the satellite images have taken.

4. This study also displayed the reliability of electrical resistivity tomography (ERT) as a high-resolution technique it was very favourable vis-à-vis locating underground cavities and sinkholes, and water channels, due to the dissolution in fractured zones. It is also completely suitable for differentiating surficial soil, clay, weathered rocks, compact or intact rocks, and air-filled karst voids or cavities, and intensely fractured rocks.

These features affect many construction sites position in the area extended over carbonate karst rocks, causing a disturbance in construction works, which can increase the overall cost of the projects.

5. The geological model is clarifying via the geophysical data, consists of a basal marbleized limestone unit and constitutes the bedrock of the study area. This bedrock unit appears to have been dissected or intervened by solution-widened joints and fractures, enclosed by overburdened layers consisting of sand, containing lenses of stiff, nonstiff moisturized clay and covered by soil mixed with friable sand and rock fragments in certain places. Intervened by sinkholes and cavities in-filled with clay or sandy clay and sand; it is interpreted as created due to karst process.

6. The interpretation of the inverse model section in construction site \#1 (Taman Batu Gagah Perdana) indicated that the area has been affected by several longitudinal trained tubular anomaly that contain stiff, non-stiff moisturized clay and sandy clay.

The interpretation of the inverse model section in construction site \#2(Gunung Rapat) indicated that the area has been affected by a thick cover of alluvium deposits contain several lenses contain both stiff and non-stiff clay highly moisturized, making the area hazard.

The interpretation of the inverse model section in construction site \#3 (Ipoh city) indicated that the area has been affected by many sinkholes contain stiff clay, sandy clay, and sand.

The interpretation of the inverse model section in construction site \#4 (Taman Tasek Jaya) indicated that the area has been affected by many of tubular anomalies represent fractures in bedrocks and contain both stiff clay, sandy clay and sand.

The interpretation of the inverse model section in construction site \#5 (Klebang Putra) indicated that the area has been exaggerated by a numerous of sinkholes and thus contains stiff, non-stiff clay and saturated with water. These features are harmful and making the area hazardous as they are packed with material sandy or silty clay, which could collapse when subjected to piping under the load construction structures.

7. The geophysical data indicated that the depth of limestone bedrock topography was asymmetrical or uneven, containing many pinnacles and cutters. In construction site \#1, the depth of weathered limestone bedrock was variable between $17.0 \mathrm{~m}$ and $>28.0 \mathrm{~m}$. For intact limestone bedrock, the depth varied between $22.0 \mathrm{~m}$ and $>28.0 \mathrm{~m}$, and the depth of pinnacles varied between $17.0 \mathrm{~m}$ and $24.0 \mathrm{~m}$.

In construction site \#2, the depth of weathered limestone bedrock mottled between $20.0 \mathrm{~m}$ and $28.0 \mathrm{~m}$. The depth of an intact limestone bedrock varied between $21.0 \mathrm{~m}$ and $>28.0 \mathrm{~m}$, while the depth of its pinnacles varied between $20.0 \mathrm{~m}$ and $27.0 \mathrm{~m}$.

In construction site \#3, the depth of weathered limestone bedrock mottled between $3.0 \mathrm{~m}$ and 28.0 $\mathrm{m}$. The depth of intact limestone bedrock varied between $6.0 \mathrm{~m}$ and $>28.0 \mathrm{~m}$, and the depth of pinnacles varied between $5.0 \mathrm{~m}$ and $12.0 \mathrm{~m}$.

In construction site \#4, the depth of weathered limestone bedrock mottled between $1.50 \mathrm{~m}$ and 12.4 
m. The depth of intact limestone bedrock varied between $1.5 \mathrm{~m}$ and $22.0 \mathrm{~m}$, and the depth of pinnacles is unclear in this site.

In construction site \#5, the depth of weathered limestone bedrock mottled between $3.0 \mathrm{~m}$ and $>28.0 \mathrm{~m}$. The depth of intact limestone bedrock varied between $8.0 \mathrm{~m}$ and $>28.0 \mathrm{~m}$, and the depth of pinnacles varied between $3.0 \mathrm{~m}$ and $19.0 \mathrm{~m}$.

8. The origin of the Karst features in construction site \#1 previously mentioned were due to heavy rainwater runoff on the ground surface channeling down into the subsurface leading the porous layers to produce uneven deep sloping channel pipes created by the slow dissolution processes which then rapidly packed with washed materials from the ground surface. The sinkholes in the study area were considered by referring to the mechanisms of the ground failure, and the nature of the material that fails and subsides.

While the origin of Karst features in construction site \#2 appears to be new. The early stages of a soil-cover karst collapse may appear as a soil-piping feature; most soil cover collapse sinkholes locations are soil materials dominated by porous layers, with thickness of $\geq 9 \mathrm{~m}$, highly weathered condition of underlying karstified carbonate bedrock, with positions adjacent to a main active sinkhole.

The sinkhole in construction site\#3 due to the sudden appears of a soil covers collapse sinkhole. Initiated when the development of small voids at a depth of a few meters down in the soil, or unconsolidated cover overlaying karst bedrock. Then enlarged either by the loss of cohesion and loading of the arch-forming material, which is in turn caused by a saturation of the soil through rainwater precipitation, or by the rapid draining of a submerged void, which also increases the pore pressure.

However, the origin of karst features in construction site\#4 is suspension channel pipes and cavities created by slow dissolution processes in the limestone bedrock. The writer thought it to be preexisting features, such as a set of joints and fractures in the carbonate rock actually developed over geological time scales. It had formed into a strongly outstanding solution-widened joint for rainfall activity and runoff water on the surface. These larger features still have a cavity in some points that are packed with silty sand, sandy clay and other materials.

The analyses led to the conclusion that the origin of Karst features in construction site \#5 appears to be a collapse sinkhole created by a smallscale collapse in the surface that occurred due to the presence of subsurface structural features. Then, the earliest collapse sinkhole was packed with soil, sediment, and fragments due to the modifications to the surroundings, and finally resulting in the sinkhole being buried. Another Surface subsidence may then take place, due to compaction of the soil.

9. The geophysical data also indicated that the different kinds of subsurface karst features originated geohazardous areas in many locations along the study sites. The most geohazard area in construction site \#1 was found beneath and between E 17 and E 30 in resistivity traverse no. 2 and extended in resistivity traverse no. 3 and traverse no. 4 which affected by several of irregular tubular channels with a maximum depth of $>28.7 \mathrm{~m}$. These features are harmful because containing of stiff clay, non-stiff moisturized clay, and sandy clay.

10. The most geohazard area in construction site \#2, have found beneath resistivity traverse no.1, between E 7and E 33. Extended also in resistivity traverse no.2, traverse no. 3 and traverse no. 4 which affected by various types of soil cover collapse sinkholes, soil pipes, and lenses. Several of these features reaching depths range between $12.0 \mathrm{~m}$ to $15.0 \mathrm{~m}$, while others reaching the maximum depth of $\sim 19.0 \mathrm{~m}$. These features are harmful because some were in-filled with water, while others with thick clay or with sandy or silty clay, which could collapse when subjected to piping under a load of structures.

In construction site \#3, the most geohazard area were found beneath traverse no.3, between E 30 and $E 79$, with various types of soil cover collapse sinkholes, some extending about $15.0 \mathrm{~m}$ to $20 \mathrm{~m}$, with an of $\sim 19.0 \mathrm{~m}$, others with maximum depth $34.0 \mathrm{~m}$. These features are harmful because some are infilled with water, while others with thick clay, sandy or silty clay that could collapse when subjected to piping under a load of structures. In addition, lenses with various depths and sizes have extended between $15.0 \mathrm{~m}$ to $75.0 \mathrm{~m}$, with a maximum depth of $\sim 22.0 \mathrm{~m}$. Some contain thick clay, while others are in-filled with sandy or silty clay.

In construction site \#4, the most geohazard area were found beneath resistivity traverse no.1, between E1 and E17. The geohazard area also extended into the resistivity traverse no.2, resistivity traverse no.3, and resistivity traverse no. 4 becoming wider between E1 and E25, that were affected by sinkholes extending about $80.0 \mathrm{~m}$, with a maximum depth of $\sim 28.0 \mathrm{~m}$. This sinkhole was harmful because it connects to a dissolution channel under the site. In addition, lenses with various depths and sizes are found. Some are in-filled with silty sand, while the others are in-filled with sand.

In construction site \#5, the most geohazard area found to be underneath resistivity traverse no.6, with sinkholes extending over $55 \mathrm{~m}$ and reaching depths of more than $28.7 \mathrm{~m}$. Once the excavating work over resistivity traverse no. 5 was started, the underground water gushed out immediately; which confirms the geophysical survey that there was a 
high conductivity and very low resistivity source representing ground water body under this profile

11. In accordance with the characteristics of the morphological features of karst ground conditions by A. C. Waltham and P. G. Fookes (2005).This classification divides the Karst terrains on planet earth into five classes. The five classes illustrate the karst terrains in terms of the difficulty and complexity that come across the foundation engineers. From these classifications, the carbonate karst regions in Malaysia classified as extremely karst terrains.

12. Through the study of karst regions found that, the strength of karstification is different from one site to another in the same region. A geotechnical table for engineering classification of karst ground conditions which presented by Yassin, R. R. \& Haji Tap, S. (2012) which describe the subsurface features that come upon in engineering works on karst terrains, after applying of the geotechnical survey. This table applies in Malaysia peninsular and includes five (5) classes, start from Youthful karst (KaI) and ending with extremely complex karst (KaV).

The karst class in construction site \#1 found between traverse no. 1, traverse no. 2 is adult karst, and between traverse no. 3 , traverse no. 4 is a mature karst KaIII, due to the presence of several of soil covers collapse sinkholes, lenses, voids, cavities, channel pipe, and severe pinnacles.

The karst class in construction site \#2, found between traverse no.1, traverse no. 4 is a mature karst KaIII, due to the presence of numerous types of sinkholes and with different sizes, voids, soil fissures, and severe pinnacles.

The karst class in construction site\#3 found between traverse no. 1 , traverse no. 2 is a mature karst KaIII and in profile 3 is a complex KaIV due to the presence of several of soil covers collapse sinkholes with different sizes, voids, soil fissures, lenses, cavity, caves, and severe pinnacles.

The karst class in construction site\#4 found between traverse no. 1 , traverse no. 4 is mature karst KaIII due to presence of dissolution channel pipe, widened fractures, cavities and severe pinnacles.

The karst class in construction site\#5 found between traverse no.1, traverse no. 6 is a mature karst KaIII - Complex karst KaIV, due to the presence of massive sinkhole, lenses in-fill with clay or water, severe pinnacles.

13. Through the comparison between the boring data by auger and geophysical data found that there is a small difference in the depth between the depth from geophysical interpretation sections and the depth from the geological report of drilling by auger about $2.0 \mathrm{~m}$ to maximum5.0m if the ground surface cover with sand and/or rock fragments.
14. Early engineering subsurface remediation techniques are needed to mitigate or minimize the potential of geohazard of karst features in these construction sites over karst carbonate bedrocks. Initial consideration is utilizing the reverse graded filter technique to fill the huge sinkhole in construction. Skin friction piles have driven into the layers containing non-stiff materials (soil, clay, silt, sand).

The Driven of long piles down to the sound bedrock is due to the difference in the depth of bedrock from one construction site to another. Furthermore, the need for a new process of grouting method in the study areas as chemical grouting techniques and controlling surface and subsurface water drainages. All of these plans must be put into operation in these sites place when the work is beginning at these respective sites. One of the steps of environmental management in oil and gas exploration uses of the Bentonite drilling mud and the rock gutting from the drilling operation after the water and other liquids have removed to refill the depression and sinkholes in karst regions.

15. This study found that the sinkholes formations are likely to form in regions mostly located in the southern part of the western belt of limestone hills and an east-west line across Ipoh. Within the region of carbonate karst environment, extended from Tapah city, which located in the south of the valley, until Kuala Kangsar city, which located in the north of the valley. In the cities such as Pulai, Gopeng, Rapat, Batu Gajah, Kampar, Ipoh, Taman Tasek, Putra Klebang, and Klebang Restu (Kinta Valley) Perak state. All of these cities in over carbonate karst environment are former tin mines. Some of these sinkholes spotted and marked in satellite images and found distributed within two zones. The first zone has to trend from the south to the northnortheast of the valley. However, the second zone has trended from the south to the north-northwest of the valley.

16. In addition, this study confirms that the mining and human activities in the Perak region, air and water high pollution, and heavy rains directed to soil erosion and subsidence. The natural of Karst features in the carbonate bedrocks such as severe and uneven pinnacles topography, cavities and linear trenches all contribute or provide the geologic settings for the development of sinkholes. Manmade factors or activities such as changing the groundwater level by pumping for watering the farm and deep excavations to open cast mining can generate the formation of sinkholes, the occurrence of rockfall, soil erosion, and subsidence. In addition, excavations of the lands, removing the trees for constructions projects works, all these elements after the developed of the karst features rapidly in this tropical area of Peninsular Malaysia. 
Therefore, sinkhole found development is more common in the pure limestone with a high content of calcium carbonate over $95 \% \mathrm{CaCO}_{3}$. While the more dolomitized karst areas with a high content of magnesium carbonate $40 \% \mathrm{MgCO}_{3}$ are less level to the sinkhole development. Therefore, it is reasonable that sinkhole problems have become the common interest not for geologists and engineers only, but also for city planners and even enterprise or project manager.

17. There are several causes for the occurrence of sinkhole collapse in the Kinta Valley; the primary reason among them is the irregular distribution of unconsolidated material on the bedrocks surface. The secondary reason is the running of heavy rainwater on the ground surface. The third reason is the heavy acidic rainfall in this region. The fourth reason is the earthquakes and the subsidence movement. The fifth reason is the heavy loads of buildings or foundations. The sixth reason is the human influence. The seventh reason is the vibration from traffic. The eight reasons are the weather patterns. The ninth reason is the groundwater movement. The tenth reason is the water quality. The eleventh reason is Air high pollution. All these reasons after the development of the sinkholes and other karst feature rapidly in this tropical area of Peninsular Malaysia.

18. The geotechnical survey identifies that the thin red cover that contains the different sizes of granite rocks and minerals with thickness is mostly about $(5.0 \mathrm{~cm}-12.0 \mathrm{~cm})$. This thin red cover found over a layer of lateritic clay with different thickness from site to another between $(1.0 \mathrm{~m}-1.25 \mathrm{~m}),(2.0 \mathrm{~m}-$ $5.0 \mathrm{~m})$ and with the maximum thickness $(6.0 \mathrm{~m}$ $9.0 \mathrm{~m})$ are mostly returns to the period of a global flood (Noah's Flood) (3300-3100) BCE.

The appearance of this thin red cover and the layer of lateritic clay are due to runoff heavy rains that have deeply eroded and washed both the highest granite ranges around the Kinta valley and then carried away by the new rivers and canyons that formed due to the erosion. A thin layer of carboniferous organic material with different thickness of $(3.0 \mathrm{~cm}-5.0 \mathrm{~cm}),(8.0 \mathrm{~cm}-10.0 \mathrm{~cm})$ have seen beneath the lateritic clay.

\section{CONCLUSIONS}

This research study focuses on the combination of geological, geophysical, aerial photographs, satellite image and accompanying engineering subsurface remediation techniques as identifications techniques to mitigate the geohazard of carbonate karst features in construction sites. The techniques were performed across five construction sites north and south Ipoh city, Kinta Valley, Perak state, Peninsular Malaysia. Construction site \#1 is located at Batu Gagah Perdana in the southwest of Ipoh city. Construction site \#2 is located at Rapat in the southeast of Ipoh city.
Construction site \#3 is located in Ipoh city. Construction site \#4 is located at Taman Tasek Raya in the north of Ipoh city. Construction site \#5 is located at Klebang Putra - Klebang Green in the northwest of Ipoh city.

Two-dimensional (2D) electrical resistivity tomography (ERT) surveys have carried out across the five constructions sites in order to image the subsurface and locate evidence for near-surface karst features such as voids or cavities including sinkholes and to estimate the depth of the bedrock. Furthermore, to estimate the reliability of (ERT) geophysical technique in recognizing such karst features or not. Resistivity traverses were conducted along the survey area at each of the five construction sites. The orientation, extension and the degree of inclination of those traverses are shown in the location maps. The correct resistivity data was interpreted using res2dinv software. An assessment of the situation was surmised from the subsurface images. Subsequently an estimation of the possibility of a collapse occurring due to many sinkholes, clay lenses and cavities were prepared.

This study also displayed that high-resolution Electrical Resistivity Tomography (ERT) can be effectively implemented to reflect the bedrocks. It is also completely suitable for differentiating surficial soil, clay, weathered rocks, compact or intact rocks, and air-filled karst voids or cavities and intensely fractured rocks. Interpretation of geophysical techniques can expose to civil engineers the irregularity in subsurface karst topography of marbleized limestone bedrocks in Perak, the degrees of karst level and the reason after the appearance of the karst features and the difference in the appearance of the karst features along these sites. In addition, the difference in the depth of bedrock from one site to the other and this mean using the piles with more length that used at this time. Also, need of new process of grouting method in the study areas.

Besides, the geological model is clarifying via the geophysical data, consists of a basal marbleized limestone unit and constitutes the bedrock of the study area. This bedrock unit appears to have been dissected or intervened by solution-widened joints and fractures, enclosed by overburdened layers consisting of sand, containing lenses of stiff, non- stiff moisturized clay and covered by soil mixed with friable sand and rock fragments in certain places. Intervened by sinkholes and cavities in-filled with clay or sandy clay and sand; it is interpreted as created due to karst process..

The geophysical data also indicated that the different kinds of subsurface karst features originated geo-hazardous areas in many locations along the study sites. The most geohazardous area in construction site \#1 was found beneath and between E 17and E 30 in resistivity traverse no.2 and extended in resistivity traverse no. 3 and traverse no. 4 which affected by several of irregular tubular channels with a maximum depth of $>28.7 \mathrm{~m}$. These features are harmful because containing of stiff clay, non-stiff moisturized clay and sandy clay. 
The geotechnical survey identifies that the thin red cover that contains the different sizes of granite rocks and minerals with thickness is mostly about $(5.0 \mathrm{~cm}-12.0 \mathrm{~cm})$. This thin red cover found over a layer of lateritic clay with different thickness from site to another between $(1.0 \mathrm{~m}$ $1.25 \mathrm{~m}),(2.0 \mathrm{~m}-5.0 \mathrm{~m})$ and with the maximum thickness $(6.0 \mathrm{~m}-9.0 \mathrm{~m})$ are mostly returns to the period of a global flood (Noah's Flood) (3300-3100) BCE.

The appearance of this thin red cover and the layer of lateritic clay are due to runoff heavy rains that have deeply eroded and washed both the highest granite ranges around the Kinta valley and then carried away by the new rivers and canyons that formed due to the erosion. A thin layer of carboniferous organic material with different thickness of $(3.0 \mathrm{~cm}-5.0 \mathrm{~cm}),(8.0 \mathrm{~cm}-10.0 \mathrm{~cm})$ have seen beneath the lateritic clay.

In accordance with the geotechnical table for engineering classification of karst ground conditions presented by Yassin, R., R. \& Haji, Taib, S. (2012) which describe the subsurface features that come upon in engineering works in semi-wet and wet tropical karst region. This table applies in Malaysia peninsular and includes five (5) classes, start from Youthful karst (KaI) and ending with extremely complex karst $(\mathrm{KaV})$.

The karst class in construction site \#1 found between traverse no. 1, traverse no. 2 is adult karst, and between traverse no.3, traverse no. 4 is a mature karst KaIII. The karst class in construction site \#2, found between traverse no.1, traverse no. 4 is a mature karst KaIII. The karst class in construction site \#3 found between traverse no.1, traverse no. 2 is a mature karst KaIII, and in traverse, no. 3 is a complex KaIV. The karst class in construction site\#4 found between traverse no. 1 and traverse no. 4 is a mature karst KaIII. The karst class in construction site\#5 found between traverse no. 1 and traverse no. 6 is a mature karst KaIII - Complex karst KaIV.

This study also discusses many considerations about the important elements that play major roles in the development of karst phenomena and the dissolution process in (Kinta Valley). Mining and human activities, air and water high pollution, and heavy rain developed the karst features rapidly in this tropical area of Peninsular Malaysia.

There are several causes for the occurrence of sinkhole collapse in the Kinta Valley; the primary reason among them is the irregular distribution of unconsolidated material on the bedrocks surface. The secondary reason is the running of heavy rainwater on the ground surface. The third reason is the heavy acidic rainfall in this region. The fourth reason is the earthquakes and the subsidence movement. The fifth reason is the heavy loads of buildings or foundations. The sixth reason is the human influence. The seventh reason is the vibration from traffic. The eight reasons are the weather patterns. The ninth reason is the groundwater movement. The tenth reason is the water quality. The eleventh reason is Air high pollution. All these reasons after the development of the sinkholes and other karst feature rapidly in this tropical area of Peninsular Malaysia.

Early planning needs to mitigate or minimize the hazard of karst features in these construction sites over karstified carbonate bedrock. Initial consolidations of reverse graded technique, driven long piles to the sound bedrock due to differences in the depth of bedrock from one site to the other. Besides, the need for a new process of grouting method in the study areas as chemical grouting techniques and controlling surface and subsurface water drainages must put into operation in these sites. In addition, this study confirms that the mining and human activities in Perak region, air and water high pollution, and heavy rains directed to soil erosion and subsidence.

Note:

This paper presented by the Author Riyadh R. Yassin, in the sixth international conference of geo-resources and geological engineering, Yogyakarta on 11-12 December 2013, Indonesia

\section{REFERENCES}

[1] Beck B.F., Herring J.G. (2001). Geotechnical and Environmental Applications of Karst Geology and Hydrology, Balkema Publishers, pp. 341-346.

[2] Chan S.F. (1986). Foundation problems in limestone area, of peninsular Malaysia, Geotech. Engineering Div., IEM, Sep1986, pp. 98 .

[3] Chang K. S., Wong S.L. (2009). The limestone hills and caves of the Kinta Valley) Malaysian Nature Society, Kuala Lumpur, Malaysia p. 151

[4] Chow W.S., Jamaludin O., Loganathan, P. (1996) Geotechnica problems in limestone terrain with emphases to cavities and sinkholes pp.102-117.

[5] Cobbing E.J., Pitfeld P.E., Derbyshire D.P., Mallick D.I. (1992) The granites of Southeast Asian tin belt, Overseas Memoir 10, British Geological Survey of London, pp. 78-86.

[6] Dahlin, T. (1996) 2-D resistivity surveying for environmental and engineering applications, First Break, 14(7), pp. 275-283.

[7] David P., Panagiotis T., Konstantinos A. (2008) Electrical resistivity tomography mapping of beach rocks, application to the island of Thassos (N. Greece), Environ. Earth Sci. (2009) 59:233-240 DOI 10.1007/s12665-009-0021-9.

[8] Fischer J.A., Candace R. (1989) Foundation Engineering Construction in Karst Terrain, In Foundation Engineering. Current Principles and Practices, Proc. Conf., Eveston, Illinois, ASCE, USA, 1989, pp. 29-42.

[9] Fontaine H., Ibrahim B. A. (1995) Biostratigraphy of the Kinta Valley, Perak, Geol. Soc. Malaysian Bulletin, Vol. 38, pp.159-172.

[10] Gobbett D.J (1964) The Lower Paleozoic Rocks of Kuala Lumpur, Malaysia, Federation Museum's Journal, Vo.9, 67-79.

[11] Hoover R.A., Saunders W.R. (2000) Evolving Geophysical Standards, in The First International Conference on the Application of Geophysical Methodologies \& NDT to Transportation Facilities and Infrastructure Conference Proceedings, Missouri Department of Transportation.

[12] Hu, R.L., Yeung, M.R., Lee, C.F., Wang, S.S. \& Xiang, J.X. (2001) Regional risk assessment of karst collapse in Tangshan, China. The Journal of Environmental Geology, Vo.40, pp. 1377-1389.

[13] Hussein I. E., Kraemer G., Myers R.( 2000) Geophysical characterization of a proposed street extension in Cape Girardeau, Missouri. Proceedings of the First International Conference on the Application of Geophysical Methodologies \& NDT to Transportation Facilities and Infrastructure.

[14] Hutchinson C.S.( 2007) Geological Evolution of Southeast Asia (2nd Edition), Geological Society of Malaysia" (Publ), 433 p. 
[15] Ingham F.T., Bradford E.P. (1960) The geology and mineral resources of the Kinta Valley, Perak. Geological Survey Distric Memoir 9, Federation of Malaya Geological Survey, Ipoh, p. 347.

[16] Ioannis F. L., Filippos I. L. \& Melanie B.( 2002) Accurate Subsurface Characterization For Highway Applications Using Resistivity Inversion Methods," Geophysics \& Geothermic Division, Geology Depart, University of Athens, Panepistimiopolis, Ilissia, Athens.

[17] Loke M. H. and Barker R. D. (1994) Rapid least-squares inversion of apparent resistivity pseudo-sections" Extended Abstracts of Papers 56thEAGE Meeting Vienna, Austria 6-10 June 1994, p. 1002

[18] Muhammad, R. F. (2003). The Characteristic and the Origin of the Tropical Limestone Karst of the Sungai Perak Basin, Malaysia. Unpubl. PhD, University of Malaya, p. 443.

[19] Muhammad R. F., Yeap E. B. (2002) Estimating Dissolution Rates in Kinta and Lenggong Valleys the Micro Erosion Meter, Geol Soc Bull. V45, pp. 26-27.

[20] Neil L. Anderson, Derek B. Apel, Ismail B. A. (2007). Assessment of Karst Activity at Highway Construction Sites Using the Electrical Resistivity Method, Missouri, USA.

[21] Pierson, B.J. (2009). The limestone hills of the Kinta Valley a part of Malaysia's geological heritage worth preserving. First Break, vol 27, pp. 97-100

[22] Psomiadis, D., Tsourlos, P., Albanakis, K. (2008). Electrical resistivity tomography mapping of beach rocks, application to the island of Thassos (N. Greece) Environ". Earth Sci. (2009) 59:233240 DOI 10.1007/s12665-009-0021-9.

[23] Reitz, H.M. \& Eskridge, D.,S. (1977). Construction methods which recognize the mechanics of sinkhole development, in Dilamarter R.R., and Csallany S.C. Eds Hydrologic problems in karst regions: bowling green, Western Kentucky University, Department of Geology and Geography, pp. 432-438.

[24] Seng, C. K., Wong, S.L. (2009). The limestone hills and caves of the Kinta Valley, Malaysian Nature Society, Kuala Lumpur, Malaysia, p. 151.

[25] Sowers G.F. (1996). Building on sinkholes: Design and construction of foundations in karst terrain" American Society of Civil Engineers, New York, p. 115

[26] Tan B. K. (1983). Geology and urban development of Kuala Lumpur, Malaysia, 1986, geological society of Hong Kong, Bullten No.3, oct.1987, pp.127-140.

[27] Tan B.K. (1987). Some geotechnical aspects of urban development over limestone terrain in Malaysia" Bullten of the international association of engineering geologist, pp. 35, 57, 63 .

[28] Telford, W.M., Geldart, L.P., and Sheriff, R.E. (1990), Applied Geophysics, (second add.). Cambridge University Press, New York.

[29] Waltham, A.C., Fookes, P. G. (2005). Engineering classification of karst ground conditions, Quarterly Journal of Engineering Geology and Hydrogeology vol. 36, pp. 101-118.

[30] William E. D., Jonathan E. N., Carpenter P. J., Kaufmann R. D., Bradley J. C.'( 2002) .Geophysical Surveys of a Known Karst Feature, Oak Ridge Y-12 Plant, Oak Ridge, Tennessee.

[31] Williams,B.,E.; Robinson, R.( 1993). Grouting beneath an existing dam founded on karst terrain, pp. 255-258 in Beck, B.F. (Ed.) Applied karst geology. Proceedings of the $4^{\text {th }}$. Conference on sinkholes and the engineering and environmental impacts of karst. AA Balkema, Panama City. Science for Conservation, 198-57.

[32] Williams, P.W. (1993). Environmental change and human impacts on karst terrains. An introduction in Williams, P.W. (Ed.) Karst Terrains, environmental changes, human impact. Caten Supplement 25: 1-19.58 Urich - Land use in karst terrain.

[33] Yahia N. A., Yassin, R. R., Abdel Qadir, S. O.( 1992 ) The results of Applying geophysical techniques in Prospecting and Investigation of Bauxite Ore deposits in subsurface karst terrains / Iraqi western desert, Rep.no.2262, geosurv, Baghdad - Iraq.

[34] Yahia N. A., Yassin, R. R., Hijab S. R. (1994) The application of complex geophysical techniques to detecting and locating the Weakness zone and the water seepage in the body of the ALTharthar dam , samara town, Salahuddin province / Iraq , Geosurv. / Baghdad - Iraq, NI-38-10, SEGSM, 2265.

[35] Yassin R. R., Hj Taib S., Muhammad R. F.(2013) Reliability of Wenner ER Tomography and satellite image techniques in recognizing and assessing the geohazard development of subsurface carbonate karst features in selected construction sites in (Kinta valley) Perak, Peninsular Malaysia" The fifth regional conference on Geological Engineering, Kuala Lumpur, Malaysia.ISBN:978-9670380-23-0.

[36] Yassin R. R. (2002) evaluates the presence of karstic Bauxitic clay deposits in parts of western desert of Iraq by the application of VLF - electromagnetic and Electrical resistivity techniques" MSc. thesis submitted to Department of Geology, college of science, University of Baghdad-Iraq, p. 293.

[37] Yeap E.B. (1985) Irregular topography of subsurface carbonates bedrock in Kuala Lumpur area, Malaysia" The 8th southeast Asia Geotechnical Conference, Kuala Lumpur, V1, pp.12.

[38] Zhou, W., Beck, J.B., Stephenson, (2000). Reliability of dipoledipole electrical resistivity tomography for defining depth to bedrock in covered karst terrains. Environmental Geology 39(7):760-766 - January 2000. 